\title{
The Corporate Headquarters in the Contemporary Corporation: Advancing a Multimarket Firm Perspective
}

\section{Citation}

Menz, Markus, Sven Kunisch, and David J. Collis. "The Corporate Headquarters in the Contemporary Corporation: Advancing a Multimarket Firm Perspective." Academy of Management Annals 9 (2015): 633-714.

\section{Published Version}

http://www.tandfonline.com/doi/abs/10.1080/19416520.2015.1027050

\section{Permanent link}

http://nrs.harvard.edu/urn-3:HUL.InstRepos:22836597

\section{Terms of Use}

This article was downloaded from Harvard University's DASH repository, and is made available under the terms and conditions applicable to Open Access Policy Articles, as set forth at http:// nrs.harvard.edu/urn-3:HUL.InstRepos:dash.current.terms-of-use\#OAP

\section{Share Your Story}

The Harvard community has made this article openly available.

Please share how this access benefits you. Submit a story.

\section{Accessibility}




\title{
THE CORPORATE HEADQUARTERS IN THE CONTEMPORARY CORPORATION: ADVANCING A MULTIMARKET FIRM PERSPECTIVE
}

\author{
Markus Menz \\ School of Management, University of St. Gallen \\ Dufourstrasse 40a, 9000 St. Gallen, Switzerland \\ +41712247612 \\ markus.menz@unisg.ch \\ Sven Kunisch \\ School of Management, University of St. Gallen \\ Dufourstrasse 40a, 9000 St. Gallen, Switzerland \\ +41712247622 \\ sven.kunisch@unisg.ch \\ David J. Collis \\ Harvard Business School, Harvard University \\ Soldiers Field, Boston, MA 02163, United States \\ $+16174956768$ \\ dcollis@hbs.edu
}

\section{Acknowledgments}

We would like to thank Laura Cardinal, Sim Sitkin, Laurie Weingart, and two anonymous reviewers for their valuable feedback and guidance. We also thank Juan Alcacer, Björn Ambos, Julian Birkinshaw, Andrew Campbell, Steven Floyd, Robert Kaplan, Günter Müller-Stewens, Torsten Schmid, and Metin Sengul for their helpful comments and insightful discussions.

\begin{abstract}
The corporate headquarters (CHQ) is the central organizational unit in the contemporary corporation, and is critical for value creation in the overall firm. Since the early 1960s, a significant body of research on the CHQ has evolved along two separate but related streams. The first stream focuses on the CHQ in the multibusiness firm, while the second stream concerns the CHQ in the multinational firm. In this article, we promote a consistent multimarket firm perspective that draws on research in both streams. First, we describe the origins and evolution of CHQ research in each stream, and articulate the benefits of a multimarket firm perspective. Second, we integrate the conversations found in the two streams into a schematic framework, review the studies' findings, and establish a shared language. We also propose ways in which scholars in each stream might enrich their work by incorporating some of the theories, methods, and findings of the other stream. Third, we discuss four fundamental inquiries for future research that draw upon the cumulative CHQ research in both streams. Overall, this article informs the study of the CHQ and, thereby, contributes to our understanding of the contemporary corporation.
\end{abstract}

\section{Keywords}

Corporate headquarters, corporate center, corporate parent, multimarket firm, multibusiness firm, multinational corporation. 


\section{INTRODUCTION}

The corporate headquarters (CHQ) is the central organizational unit in the contemporary corporation (Chandler, 1991; Collis, Young, \& Goold, 2007). These firms are characterized by a portfolio of diverse product and geographic operating units coordinated by the CHQ, and have become the dominant organizational form of business. According to the McKinsey Global Institute (2013, p. 2), these firms generated global revenues of $\$ 57$ trillion in 2010 - equivalent to $90 \%$ of global GDP - and are expected to grow to $\$ 130$ trillion by 2025 . In such firms, the CHQ serves as an intermediary between the internal and external contexts and is critical for value creation in the overall entity, thus, economically justifying its existence across market boundaries (Collis \& Montgomery, 1998). Not surprisingly, the CHQ is central to many theories that explain the functioning of the firm (Kleinbaum \& Stuart, 2014).

Since the publication of Chandler's (1962) seminal work on the development of the multidivisional-form (M-form) organization in the American industrial enterprise in the early 1960s, a significant body of research on the CHQ has evolved along two somewhat separate research streams. The first stream concerns the CHQ in the multibusiness firm-a firm that is active across different product markets. In this stream, scholars have analyzed the CHQ's roles and activities (e.g., Chandler, 1991; Foss, 1997), its resources and capabilities (e.g., Adner \& Helfat, 2003; Song, 2002; Tan \& Vertinsky, 1996), as well as its design and staffing (e.g., Collis et al., 2007; Kleinbaum \& Stuart, 2014). The second stream deals with the CHQ in the multinational firm — a firm that operates across several geographic markets (Bartlett \& Ghoshal, 1989). Researchers active in this stream have primarily explored CHQ (re-)location (e.g., Birkinshaw, Braunerhjelm, Holm, \& Terjesen, 2006; Laamanen, Simula, \& Torstila, 2012) and CHQ-international subsidiary relationships (e.g., Bouquet \& Birkinshaw, 2008; Nell \& Ambos, 
2013). Scholars' focus on specific phenomena from these different perspectives has led to CHQ research in the two streams becoming increasingly disconnected. This disconnect impedes fertilization across the two streams and, thus, complicates taking stock of our collective knowledge of the CHQ.

Both research streams address the fundamental issue of how the CHQ creates value across different product or geographic markets and view the CHQ's fundamental organizational challenge as the achievement of a balance between the "differentiation" and "integration" of its constituent elements (Lawrence \& Lorsch, 1967). Hence, a multimarket firm perspective on the CHQ that builds on research in both streams has the potential to fuel advances in our understanding of the CHQ and, more generally, of the functioning of the contemporary corporation. Chandler's (1991) labeling of the firms he studied as "multimarket business enterprises" (1991: 33) and the decades-old observation that most large diversified companies are also multinationals (Prahalad \& Doz, 1987) have long highlighted the need for such a perspective. Indeed, given that most modern corporations are multibusiness and multinational organizations, and differences between business and geographic units are often not clear cut (e.g., Campbell, Alexander, Goold, \& Whitehead, 2014), it is no surprise that scholars advocate closer links between the literatures on corporate and international strategy (e.g., Campbell et al., 2014; Teece, 2014).

The purpose of this article is to review and evaluate extant knowledge on the CHQ in order to stimulate future research on the CHQ in the multimarket firm. First, we describe the origins and evolution of research in each stream, and articulate the benefits of a multimarket firm perspective on the CHQ. Second, we integrate the conversations in the two streams into a schematic framework, review the studies' findings, establish a shared language, and discuss their 
different contributions to our understanding of the fundamental issues concerning the multimarket firm's CHQ. We also propose ways in which scholars might enrich their work by incorporating some of the theories, methods, and findings of the other stream. Moreover, we highlight unresolved discussions, inconclusive and conflicting findings, and how the differing research foci may usefully inform the other stream. Third, we suggest four fundamental inquiries, which emerge from cumulative work within the two streams, for future CHQ research. While we do not promote full integration across the two streams, which may be infeasible and unwarranted, we do hope that this review will help scholars in each stream better understand their counterparts and allow them to build on each other's work more effectively. Overall, we expect this review to redirect attention to the fundamental issues associated with the CHQ in the multimarket firm.

\section{TOWARD A MULTIMARKET FIRM PERSPECTIVE ON THE CHQ}

The roots of CHQ research date back to at least the 1920s (Knight, 1921; Unknown, 1929), and reflect the emergence of a central organizational unit separated from the operational units at the beginning of the 20th century (Melman, 1951; Sloan, 1964). Knight (1921) adopts the term "cephalization" from biology to describe the evolutionary process that yielded organizational forms consisting of a set of individual businesses and a distinct CHQ (Foss, 1997: 326). He argues that the "centralization of this deciding and controlling function [...] is inevitable, as for the same reasons as in the case of biological evolution" $(1921$, p. 268). The cephalization process yields specialized roles for executives at the business and CHQ levels (Vancil \& Lorange, 1975). Subsequent to this early work, Peter Drucker's (1946) The Concept of the Corporation, Alfred Chandler's (1962) Strategy and Structure, and Alfred P. Sloan's (1964) 
My Years with General Motors contributed substantially to our initial understanding of the role of the CHQ in the modern corporation, which Nobel Laureate Oliver E. Williamson (1991) later acknowledged.

It was especially Chandler's (1962) seminal book Strategy and Structure: Chapters in the History of the American Industrial Enterprise that triggered research on the CHQ. Based on indepth archival studies of DuPont, General Motors, Standard Oil (New Jersey), and Sears, Roebuck and Company, Chandler (1962) describes the development of the "multidivisionalform" (M-form) organization as an effective response to the expanding range of businesses within the corporate portfolio. The separation of strategic tasks related to the overall management of the company, which are performed in a discrete CHQ unit, from the operations of the individual businesses characterizes the M-form organization-probably the most noteworthy organizational innovation of the 20th century (Chandler, 1991, 1992; Williamson, 1985). As an indication of the importance of the CHQ for these organizations, Chandler devotes an entire chapter, General Motors-Creating the General Office, to the central organizational unit - the unit in which "general executives and staff specialists coordinate, appraise, and plan goals and policies and allocate resources for a number of quasi-autonomous, fairly self-contained divisions" (1962, p. 9).

\section{Two Streams of CHQ Research}

Since Chandler's (1962) seminal contribution, research on the CHQ has evolved along two separate but related streams, each characterized by distinct research traditions, phenomena, and methods, as displayed in Table 1. The first stream encompasses studies on the CHQ in the multibusiness firm. Chandler's (1962) research influenced many of the early studies published in 
the 1960s and 1970s, which largely originated from Harvard Business School and concerned the organizational design of the multibusiness firm and the unique functions of the CHQ (e.g., Berg, 1969; Berg, 1977; Chandler, 1962; Lorsch \& Allen, 1973; Pitts, 1976, 1977). The focus on the multibusiness firm reflected the challenges executives faced at that time regarding developing and executing the firm's corporate strategy, especially the firm's product-diversification strategy (Chandler, 1991), as well as the spread of the M-form organization (Fligstein, 1985).

Insert Table 1 about here

This stream of research draws upon economic perspectives that focus on the role and governance style of the CHQ, as well as on its relationship with the firm's operating units in creating long-term shareholder value. Its research is both conceptual (including formal modeling) and empirical, with quantitative analyses of large-scale data. These studies build on transaction cost theory (Coase, 1937; Williamson, 1975, 1981), agency theory (Berle \& Means, 1932; Jensen \& Meckling, 1976), and the efficient market hypothesis (Fama, 1970), which is a pillar of financial economics (Markovitz, 1952; Modigliani \& Miller, 1958) to explain how extending the scope of the hierarchical corporation across businesses is economically more efficient than the market organization of activities.

CHQ research in this tradition also draws on diverse organizational and strategic theories, especially the resource-based view of the firm (Barney, 1991; Penrose, 1959; Wernerfelt, 1984), and often adopts a contingency argument (Chandler, 1962) to offer explanations for the various CHQ roles and activities, and their suitability for different corporate strategies (e.g., Chandler, 1991; Collis et al., 2007; Hill, Hitt, \& Hoskisson, 1992). Other scholars, however, develop normative frameworks derived from conceptual reasoning and/or based on qualitative field studies. For example, the "parenting theory" draws attention to the CHQ's value-adding roles in 
the multibusiness firm (e.g., Alexander, 1992; Goold \& Campbell, 1987; Goold, Campbell, \& Alexander, 1994).

Common to most research in this stream is a top-down perspective on the role of the CHQ in the multibusiness firm, which assumes that the CHQ is, ultimately, "in control" of the firm's differentiated product units, and that the CHQ's governance systems and management interventions somehow create value for the overall firm. Even the term "parenting" suggests that the CHQ somehow oversees and improves the performance of its "children," which are the individual businesses. In other words, these children are viewed as benefiting from their membership in the corporate portfolio.

The second stream of research deals with the CHQ in the multinational firm. While several studies in the late 1960s and 1970s considered the unique features of the multinational firm and generated normative insights concerning the CHQ (e.g., McInnes, 1971; Parks, 1974; Rutenberg, 1969; Schollhammer, 1971), the seminal contributions by Baliga and Jaeger (1984) and Prahalad and Doz (1987), as well as Bartlett and Ghoshal's (1989) book Managing Across Borders: The Transnational Solution, served to fuel research in this stream with an emphasis on the organizational challenges confronted by the CHQ when integrating activities across the diverse product market, factor market, and institutional conditions of different geographies.

Even though the literature on the multinational firm's CHQ seems somewhat younger and less extensive, it also relies on a variety of theoretical perspectives, such as control theory (Eisenhardt, 1985; Ouchi \& Maguire, 1975), resource-dependence theory (Pfeffer \& Salancik, 1978), and network theory (Granovetter, 1973), to contribute to our understanding of CHQinternational subsidiary relationships (e.g., Ambos, Andersson, \& Birkinshaw, 2010; Chen, Park, \& Newburry, 2009; Law, Song, Wong, \& Chen, 2009; Martinez \& Ricks, 1989; Nell \& Ambos, 
2013). Furthermore, in addressing the increasing globalization of large corporations, many of this stream's studies draw upon the eclectic theoretical perspective of internationalization and international business (e.g., Ciabuschi, Forsgren, \& Martín, 2011; Tan \& Vertinsky, 1996). Indeed, some studies that examine the CHQ's geographic (re-)location (e.g., Birkinshaw et al., 2006), or the international differences between multinational firms' CHQ (e.g., Collis, Young, \& Goold, 2012), explicitly adopt multiple theoretical lenses.

A key characteristic of studies in this stream is that they often adopt the subsidiary rather than the CHQ perspective, focusing on international subsidiaries' capabilities and their importance for the overall firm's value creation. In this view the CHQ is considered as the network switch between the "differentiated network" of, often, fairly independent subsidiaries. In other words, the CHQ (and overall firm) is viewed as benefiting from the international subsidiaries in the firm's global portfolio. Perhaps these idiosyncrasies have led research on the multinational firm's CHQ to evolve separately from research on the multibusiness firm's CHQ.

\section{The Benefits of Integrating the Two Research Streams}

The existence of two parallel streams of CHQ research is problematic for two interrelated reasons. First, the separation impedes the accumulation of a holistic body of knowledge about the CHQ. Since both streams study the same elephant, but rely on different approaches to look at different aspects of the phenomenon - the trunk versus the legs—, integrating knowledge from the two streams will improve our overall understanding of the CHQ. Second, the divide is in sharp contrast to the reality of the CHQ in the contemporary corporation. Most large firms today operate in multiple product as well as geographic markets, with the CHQ serving as the central organizational unit for both types of operating units (e.g., Campbell et al., 2014; Chandler, 
1991). Previous research in the two streams, however, made the (conceptual) assumption that the firm has either product divisions or international subsidiaries. Thus, building on the collective insights from both research streams is an important starting point for a more comprehensive understanding of the CHQ in the contemporary corporation-the real elephant.

In light of these shortcomings and opportunities, we advocate a consistent multimarket firm perspective on the CHQ that fosters fertilization across the two research streams and builds on the cumulative knowledge of each. Notably, in both streams, there is a common, albeit unarticulated, understanding of the role played by the CHQ in multimarket firms and how that role can be structured to optimize value creation across multiple product and/or geographic markets. Similarly, the primary organizational concern for both streams is the challenge the CHQ faces in achieving a balance between the differentiation and integration of the firm's operating units that is appropriate to the firm's context (Lawrence \& Lorsch, 1967). While the two streams have dealt with these common CHQ issues, they have, however, examined different CHQ characteristics, adopted different, if complementary, perspectives, and studied unique contextual determinants, which may benefit the study of the CHQ, as specified below.

First, our comparison of the two streams of literature reveals the opportunity to incorporate CHQ characteristics that have previously only been considered in one stream. For example, while explaining the roles and design of the CHQ is a key theme in the multibusiness firm literature, remarkably few studies examine the individual CHQ roles and activities in the multinational firm (e.g., Andersson \& Holm, 2010; Birkinshaw et al., 2006; Collis et al., 2012). Conversely, research on the multibusiness firm has largely neglected the CHQ's location, either in absolute terms or relative to the business units, while the multinational firm literature strongly suggests that this CHQ characteristic matters. Acknowledging the potential relevance of the 
CHQ characteristics covered in the other stream will contribute to a more complete picture of the CHQ in multimarket firms.

Second, our integrative review serves as a foundation for reconciling the different perspectives on the CHQ. As described above, research on the multibusiness firm's CHQ has mainly followed a top-down perspective that suggests that the "CHQ is control," whereas studies on the multinational firm's CHQ have mainly relied on a "differentiated network" perspective that focuses on the international subsidiaries' contribution. For example, research on the multibusiness firm's CHQ has considered vertical integrating mechanisms, such as formal control (e.g., Goold \& Campbell, 1987; Govindarajan, 1988), whereas research on the multinational firm's CHQ has covered the "broader," more horizontal integrating mechanisms, such as socialization and shared purpose (e.g., Martinez \& Jarillo, 1989; Nohria \& Ghoshal, 1994). Beyond informing each stream, reconciling the different perspectives will also be foundational to account for the complexity of contemporary corporations that, simultaneously, employ multiple approaches to manage their portfolio of operating units.

Third, by comparing the two research streams, we can identify and learn from the organizational and environmental determinants of the CHQ considered in each stream. For example, research on the multibusiness firm's CHQ has contributed to our understanding of how the corporate strategy determines the CHQ characteristics, such as the CHQ size and corporate control system (Collis \& Montgomery, 1998; Goold \& Campbell, 1987), while the multinational firm literature offers few analogous insights on the role played by the choice of global strategy. In contrast, research on the multinational firm suggests that the differences between countries, which affect the CHQ's characteristics and the CHQ-operating unit relationships, are complex and multidimensional, as captured in Ghemawat's (2001) CAGE (Cultural, Administrative, 
Geographic, and Economic distance) framework, while studies of the multibusiness firm's CHQ have often relied on relatively narrow conceptualizations of the business portfolio's configuration. Integrating the two streams not only promises to extend our knowledge of the determinants of the CHQ characteristics in the two streams, but may also stimulate the development and application of novel, and potentially more advanced, approaches to their conceptualization, measurement, and interpretation.

In sum, the commonalities and differences between the two research streams both carry the potential for cross-fertilization and point to new directions for research on the CHQ in the multimarket firm. Indeed, a re-framing of the underlying issues can trigger advances in each stream and help identify the fundamental challenges that cut across both streams. Differences between the two streams can be exploited to validate the underlying theories of multimarket effects on the CHQ. Hypotheses derived in one stream, such as those regarding the effect of geographic distance on CHQ-operating subsidiary relationships in the multinational firm literature, can be verified by investigating the effect of the distance between the CHQ location and the product divisions in multibusiness firms.

\section{Methodology}

To provide a complete and coherent picture of the existing knowledge about the CHQ in the multimarket firm, we followed a structured approach, using multiple techniques to search for relevant literature (Short, 2009; Webster \& Watson, 2002). First, using the EBSCOhost Business Source Premier database, we searched the titles, keywords, and abstracts of articles published in leading academic and practice-oriented management journals between 1962, when Chandler's seminal book was published, and 2012. We searched for the term corporate headquarter(s), as 
well as for several common related terms: central administrative office, corporate center/centre, central office, corporate parent, parent company, parent firm, and corporate level. Second, we manually screened the identified articles and excluded those that did not relate to the study of the CHQ. Third, we identified additional articles by using a backward and forward search, and by screening forthcoming publications. We also considered books that provide historical information, insights from practice, and point to promising avenues for future research. This process led to the identification of 116 relevant publications.

We then classified each study as focusing on the CHQ in either the multibusiness firm or the multinational firm. Each author classified the works independently, and we then discussed the few cases in which our assessments diverged until agreement was reached. The very few studies that do not clearly distinguish between the two types of firms were assigned to the research stream they more closely relate to (e.g., Sengul \& Gimeno, 2013). This procedure revealed that the number of publications on the CHQ began to increase substantially in the 1980s. This growth was fuelled by publications on the CHQ in the multibusiness firm throughout the 1980s and 1990s, and then by research on the CHQ in the multinational firm (see Figure 1). Almost two-thirds of the publications focused on the CHQ in the multibusiness firm (73 publications), while the others focused on the CHQ in the multinational firm (43 publications).

Insert Figure 1 about here

\section{INSIGHTS FROM CHQ RESEARCH}

As the foundation for our review, we define the CHQ as the multimarket firm's central organizational unit, which is (structurally) separate from the product and geographic operating units, and hosts corporate executives as well as central staff functions that fulfill various internal 
and external roles for the overall firm. Even though the CHQ is usually a discrete entity, the separation from the firm's operating divisions may also be conceptual, for example, in "virtual headquarters," as the parentheses in our definition suggest. Moreover, in line with the common understanding of the CHQ in the two streams (Chandler, 1991; Foss, 1997), our definition explicitly highlights that the top management team resides in the multimarket firm's CHQ (for an overview of selected CHQ definitions, see Appendix 1).

Building on our systematic review of the literature, we identified the research foci, approaches, and findings in each research stream (for a summary of all CHQ studies included in the review, see Appendix 2). We then organized the topics into broad categories relating to the common fundamental issues and dominant relationships in the two streams. This approach enabled us to compare and contrast existing knowledge in the two streams, while ensuring that we captured the idiosyncrasies of each. Finally, we integrated the two streams' themes and relationships in a schematic framework that is illustrated in Figure 2. Specifically, the framework lists the contributions by the multibusiness firm literature (the left side of the figure) and those by the multinational firm literature (the right side) side-by-side and highlights the respective commonalities and differences in each of the fundamental issues with which the two research streams have been concerned.

Insert Figure 2 about here

Both research streams identify the common central phenomenon as the corporate headquarters' characteristics of the multibusiness or multinational firm, including the CHQ's roles, design, location, and resources, as indicated at the center of Figure 2. Second, both streams acknowledge the importance of environmental and organizational contexts in designing an effective $\mathrm{CHQ}$, as illustrated at the top of Figure 2, although the one focuses on industry 
differences and corporate strategy, and the other on country differences and global strategy. Third, both research streams refer to the common organizational problem and address the challenge the CHQ faces in achieving a balance between the differentiation and integration of the firm's operating units, whether product divisions or international subsidiaries (Lawrence \& Lorsch, 1967). As Figure 2 indicates, the two streams rely on different approaches regarding how to integrate the differentiated units-vertical and formalization versus horizontal and socialization. Fourth, the issue of how the CHQ creates economic value across different markets, whether they are product or geographic markets, by leveraging firm-specific or country-specific advantages is a common concern of both research streams. Indeed, the CHQ's effect on various divisional, $\mathrm{CHQ} /$ corporate, subsidiary, or firm level outcomes is a recurring theme in both streams, as illustrated at the bottom of Figure 2.

In the following, we will further explicate this framework, elaborate on the insights from each of the two research streams, and discuss their contributions to our understanding of the fundamental issues of the multimarket firm's CHQ.

\section{The Central Phenomenon-The CHQ's Characteristics}

While scholars in the two research streams have emphasized different CHQ characteristics, those characteristics relate to the description of the same organizational unit and, thus, are common to both streams. As the center of Figure 2 indicates, we group these characteristics into the CHQ's roles, its organizational design, its location, and its resources.

The first characteristic concerns the unique roles performed by the CHQ. In this regard, research builds largely on Chandler's (1962) work on the multidivisional firm. He originally identified three "duties" of the multidivisional firm's CHQ: (1) coordinating and integrating the 
output of the businesses, (2) providing centralized and specialized shared services, and (3) allocating the future use and appraising the present performance of resources. While various descriptions of specific CHQ roles have since evolved (Balderston, 1962; Collis \& Montgomery, 1997; Collis et al., 2007; Foss, 1997; Goold \& Campbell, 1987; Goold, Pettifer, \& Young, 2001; Hungenberg, 1993; Kono, 1999; Pettifer, 1998), they can be summarized as covering three major roles: (1) performing obligatory (public) company functions, also referred to as "minimum CHQ"; (2) providing the firm's operating units with centralized services, such as centralized HR, IT, or marketing services; and (3) value creation. The rationales for each of these CHQ roles are fundamentally different (Collis et al., 2007). The first two roles are "administrative" (Chandler, 1991) or "loss-preventive" (Foss, 1997; Markides, 2002). For example, processing information in a shared services center at the CHQ may be more efficient than in the individual units, because of scale economies (Teece, 1980, 1982). The third role is "entrepreneurial" (Chandler, 1962, 1991; Foss, 1997) and considered the most critical role of the CHQ. This role is assumed to lead to a corporate advantage (Collis \& Montgomery, 1998) through "coordinative functions governing the development, allocation, and deployment of valuable corporate resources within the hierarchy" (Collis et al., 2007, p. 388). Importantly, most studies in both research streams adopt a (implicit) contingency argument that the exact way the CHQ roles are performed will depend on the firm's environmental and organizational contexts.

Perhaps because the CHQ's value creation role is critical in justifying the existence of the multibusiness firm, scholars have identified an array of specific, potentially value-adding, CHQ activities. These include the utilization of coinsurance effects (Berger \& Ofek, 1995), organizational (re-)design (Goold \& Campbell, 2002a; Hoskisson, 1987; Howard, 1991), corporate initiatives (Darragh \& Campbell, 2001), investment-related decision making (Barton, 
Brown, Cound, Marsh, \& Willey, 1992; MacMillan \& Meshulach, 1983), the transfer of labor policies (Summers, 1965), and risk management (Miller \& Waller, 2003). The substantial amount of research on CHQ's (corporate) strategic-planning activities is particularly notable in this vein (Campbell, 1999; Greenwood, 1964; Kaplan \& Norton, 2005; Leontiades \& Tezel, 1981; Murdick, 1964; Stubbart, 1982). While these studies have improved our understanding of the nature, antecedents, and outcomes of the CHQ's value creation role, their focus on different CHQ activities has contributed to the fragmentation of our knowledge in this area.

The second characteristic of the CHQ concerns this unit's organizational design. Key insights originate from research on the multibusiness firm's CHQ - especially regarding its (a) size, (b) internal structure and staffing, and (c) changes over time (e.g., Collis \& Montgomery, 1998; Collis et al., 2007; Goold et al., 2001; Kono, 1999; Stalk Jr., 2005; Young, 1998a). Research in this area largely builds on the balance of roles performed by the multibusiness firm's CHQ and offers normative suggestions for the CHQ's effective design (Campbell, Kunisch, \& Müller-Stewens, 2012; Hanan, 1969; Thurm, 2005; Young, 1993). With regards to the size of the CHQ, the studies' findings consistently reveal that the presence of certain CHQ staff and, thus, the size of the CHQ are contingent upon the CHQ's roles. For example, based on a survey of 467 firms, Collis et al. (2007), distinguish between "obligatory" and "discretionary" staff. They find that the presence of the latter depends on the number and types of value-creating activities performed at the CHQ.

Much less is known about CHQ design in multinationals. One of the few studies on the size and staffing of the multinational firm's CHQ reveals that CHQ size increases as the geographic scope of the firm widens, and that CHQ size differs substantially across countries. Multinational firms from different countries have vastly different CHQ sizes - a median of 255 
CHQ staff for a multinational with 20,000 employees based in the US versus a median of 124 for equivalent European multinationals. This supports the notion of "administrative heritage" and highlights the geographic effect on CHQ design (Collis et al., 2012), suggesting a need to extend our understanding of the sources of CHQ design heterogeneity across settings.

Scholars have recently begun to look inside the CHQ to examine its internal structure and staffing, directing their attention to the presence of certain subunits as well as the backgrounds and behaviors of CHQ executives (e.g., Kleinbaum \& Stuart, 2014; Kunisch \& Bilhuber Galli, 2014; Stalk Jr., 2005). CHQ subunits, known as “corporate functions,” host most of the CHQ's specialist staff responsible for corporate HR, IT, marketing, and strategy (Bazzaz \& Grinyer, 1981; Campbell et al., 2012; Collis et al., 2007; Gospel \& Sako, 2010; Grant, 2003; Kaplan \& Norton, 2005; Kunisch, Müller-Stewens, \& Campbell, 2014). Even though the contemporary multimarket firm's CHQ typically comprises several of these subunits, relatively few studies have examined the nature of these units, or the strategic, structural, and other factors that predict their occurrence at the CHQ. Nevertheless, the firm's strategy and consequent organizational design have been found to have a profound effect on the extent to which the various functions are centralized at the CHQ. For instance, in a comparison of the HR functions at Procter \& Gamble (P\&G) and Unilever, Gospel and Sako (2010) find that "a relatively high degree of centralization at $P \& G$ led it to create an internal shared services center before outsourcing, whilst a more decentralized Unilever utilized outsourcing as an occasion for globally standardizing its systems and processes" (p. 1367). Despite these initial insights, however, research on CHQ design, particularly in the multinational literature, has largely treated the CHQ as a black box.

Likewise, we still have little knowledge about CHQ staffing. As one of the few studies in this area, Kleinbaum and Stuart (2014) reveal, drawing on network theory and large-scale 
analysis of email traffic, sharp differences in behavior between CHQ-level staff and staff from the line organization. By criticizing prior literature's narrow focus on the use of structure to achieve coordination, they highlight the importance of individual CHQ managers' networks for coordination tasks. CHQ staff networks are larger, more integrative, and richer in structural holes than those of their line counterparts. They conclude that "members of the corporate center do have networks that appear to be better optimized for coordinating across disparate organizational and social structures than do employees in the line organization" (p. 2). Hence, their findings suggest that CHQ staff members have different qualifications and are therefore likely to have different career paths than staff in the firm's operating units.

Notably, a sub-strand of the literature takes a temporal approach and offers insights into the redesign and transformation of the multibusiness firm's CHQ over time (e.g., Bazzaz \& Grinyer, 1981; Ferlie \& Pettigrew, 1996; Goold et al., 2001; Stubbart, 1982), which is contrary to the majority of research on CHQ design that assumes a somewhat stable entity. Based on an analysis of interviews with corporate planners in UK firms, Bazzaz and Grinyer (1981) find that the CHQ's planning subunit has increased in size and scope since the late 1960s. Noting that CHQ size has changed over time, Ferlie and Pettigrew (1996) identify CHQ change as an increasingly important phenomenon in the late 1980s and early 1990s (for a review of this specific literature, see Kunisch, Menz, \& Ambos, 2014). However, even though the empirical findings consistently reveal that the multimarket firm's CHQ changes its design (and roles) over time, there are relatively few insights into the causes and outcomes of such changes.

The third characteristic of the CHQ originates largely from research on the multinational firm and relates to the CHQ's location. While economists have at least been interested in the factors influencing the choice of the corporate location since Marshall (1890), the CHQ's 
location as a unique characteristic of this central unit has also become an important concern in the management field (e.g., Ambos et al., 2010; Baaij \& Slangen, 2013; Chen et al., 2009; Collis et al., 2012; Law et al., 2009; Martinez \& Ricks, 1989). For example, the geographic distance between the CHQ and the firm's international subsidiaries has been found to affect CHQ interactions with their subsidiaries and their profitability (e.g., Baaij \& Slangen, 2013; Boeh \& Beamish, 2011; Bouquet \& Birkinshaw, 2008). The collective findings provide support for the proposition that the CHQ's location matters for the multinational firm's success, as it may affect information processing, reflect symbolic value, and ensure proximity to financial stakeholders, or to other CHQs.

To further understand whether and how location matters, scholars have studied CHQ relocations (e.g., Baaij, Mom, Van den Bosch, \& Volberda, 2012b; Birkinshaw et al., 2006; Laamanen et al., 2012). Indeed, between 1998 and 2012, 21\% of the Fortune Global 500 firms moved their CHQs (McKinseyGlobalInstitute, 2013). Several factors in the firm's internal and external contexts have been revealed to affect the (re-)location of the CHQ (Desai, 2009). For example, Laamanen et al. (2012) find that high taxes and a high employment rate increase the likelihood of relocation, whereas a central location and low taxes increase the attractiveness of the CHQ's current location. Birkinshaw et al.'s (2006) study of Swedish firms further substantiates the suggestion that the CHQ is not a stable entity, but that it transforms over time to meet internal and external demands. Indeed, following Porter's (1990) original argument, the CHQ will not be able to capitalize on an attractive "diamond" (the local system of factor conditions; demand conditions; related and supporting industries; and firm strategy, structure, and rivalry) in geographic clusters beyond its country of domicile unless the CHQ is relocated so that it can become an "insider" in that region. 
A related recent phenomenon that has attracted scholarly attention is the disaggregation and relocation of CHQ parts and subunits, including the dispersion of certain CHQ activities and roles across multiple locations and units, or the implementation of a "dual headquarters" strategy (DuBrule, Bouquet, \& Birkinshaw, 2010). More generally, Desai (2009) observes that multinational firms are "unbundling critical headquarters functions and reallocating them worldwide" (p. 1271-1272), a process that results in different "homes," such as financial, legal, and managerial-talent homes. These developments demonstrate that location is more than a purely geographical decision - it has important implications for other characteristics, such as the CHQ's roles and capabilities (Birkinshaw et al., 2006). Hence, consideration of the interrelationships among these CHQ characteristics seems critical, particularly in research on the multibusiness firm, which has largely overlooked locational influences.

The fourth CHQ characteristic that has been studied relates to the CHQ's resources. Interestingly, the two streams differ in their treatment of the resources underlying the CHQ's value creation role. Research on the multibusiness firm's CHQ typically draws-implicitly or explicitly — on the resource-based view of the firm to explain value creation (Alexander, 1992; Batten, 2002; Campbell, 1995; Campbell, Goold, \& Alexander, 1995b; Collis \& Montgomery, 1997; Foss, 1997; Goold, 1996a; Hanan, 1969; Song, 2002). This line of inquiry has culminated in quantitative studies on the CHQ's capabilities and competencies (Adner \& Helfat, 2003; Hitt \& Ireland, 1986, 1987; Markides, 2002; Markides \& Williamson, 1994, 1996; Parmigiani \& Holloway, 2011; Yavitz \& Newman, 1982). For instance, in a survey of 185 US industrial firms, Hitt and Ireland (1986) find that "a need also exists for distinctive competencies at the corporate level" (p. 402). Another notable contribution is Parmigiani and Holloway's (2011) study of the parent-implementation capabilities of US casual-dining chains between 1998 and 2007. They 
reveal that "parents with operating expertise from related experience can help units reduce costs, learn, and enter new markets" (p. 479).

Consistent with a "parent" view of the corporation, the thrust of this work on the multibusiness firm, which is characterized by an emphasis on conceptual frameworks and case examples, is that resources embodied at the corporate level create value and determine the design of the CHQ. Campbell et al. (1995b), for example, argue that the CHQ must possess special capabilities and resources that can improve the businesses' performance, while it must also understand and adapt to the critical success factors of each business. Alexander (1992) suggests that the scope of a CHQ's roles is determined by these unique capabilities. In this regard, the emphasis is on the possession of corporate-level resources that are heterogeneously distributed across firms and, even more narrowly, on the CHQ's specific capabilities as a source of added value for the businesses. Therefore, in this research stream, the perspective is that of a top-down contribution from the CHQ to the businesses.

As a corollary, the existence of industry sectors that require different resources to gain sustainable competitive advantages gives rise to different managerial "dominant logics" (Prahalad \& Bettis, 1986) or "industry recipes" (Spender, 1989), which lead to the adoption of different CHQ roles and designs. Thus, within the multibusiness firm literature, the emphasis is on how CHQ characteristics are influenced by the building and leveraging of firm-specific advantages appropriate for the broad industry sector in which the firm operates.

In contrast, scholars concerned with the CHQ in the multinational firm have focused on the resources exploited by the corporation's presence in different geographic markets as much as on the subsidiaries' dependence on CHQ resources (Martinez \& Ricks, 1989). Therefore, their emphasis is on how the activities performed at the CHQ depend on the dispersion of the 
multinational's activities around the world as it seeks to capitalize on country-specific advantages (Rugman \& Verbeke, 2001). In this perspective, the geographic location of the CHQ, which is largely ignored in the multibusiness firm approach, becomes an important design choice. More generally, as the resources that create value in the multinational firm are dispersed among countries, this stream of literature looks less to the corporate-level entity than to the network of international subsidiaries as the source of the valuable resources that shape the firm's strategy and, hence, the CHQ.

In light of the differing research streams' insights, there is a need to improve our understanding of the resources and capabilities present in the multimarket firm's CHQ and how these affect the CHQ's design. For example, while there is already some interest in the role that international subsidiaries can play as a source of capabilities (Teece, 2014), or as centers of competence (Desai, 2009), there has been no corresponding suggestion that the firm's product divisions, as opposed to the CHQ, can contribute to the development of valuable corporate resources, and how the presence of these resources within the individual operating units, rather than those that are vested in the corporate level, might shape the CHQ. If certain product or geographic units are responsible for maintaining a particular skill or capability, the CHQ will delegate certain activities to that unit, which will change its functions and the nature of the relationship between the CHQ and at least some of the operating units. In this regard, research will build on the insight from the multinational firm that dispersing key activities to specific units, rather than retaining all value-adding functions at the CHQ, can create value (Bartlett \& Ghoshal, 1989).

In sum, while there have been contributions to our knowledge of CHQ characteristics from both research streams, combining insights and learning across the two streams remains 
beneficial. For example, while our knowledge about the CHQ roles is most fully developed in the multibusiness firm, those same roles apply to CHQs in multinationals. Yet, remarkably few studies examine the individual roles of the CHQ in the multinational firm (Andersson \& Holm, 2010; Birkinshaw et al., 2006; Collis et al., 2012), even though when operating in multiple countries with different legal systems, fiscal regimes, and accounting standards, the multinational's CHQ may face greater demands to process and consolidate information than domestic firms (Collis et al., 2012).

Conversely, whereas the essence of the findings on the multinational firm's CHQ is that location matters - even longer flight times between the CHQ and its international subsidiaries affect performance negatively (Boeh \& Beamish, 2011) — we are surprised to note that the extant multibusiness firm literature does not consider the location of the $\mathrm{CHQ}$, either in absolute terms, or relative to the business units. Indeed, the original idea of the structural and, typical, geographical separation of the CHQ from the firm's operating units suggests that the location of the CHQ matters for both multibusiness and multinational firms (Henderson \& Ono, 2008). The CHQ's geographic distance from the product divisions may affect the attention and resources provided to those units, as well as the suitability of various integrating mechanisms and different types of control systems.

\section{The CHQ's Environmental Context}

CHQ studies in both literatures explicitly regard the firm's external context as a determinant of the characteristics of an effective CHQ. Research on the multibusiness firm's CHQ focuses predominantly on industry characteristics, whereas research on the multinational firm's CHQ mainly concerns geographic features in the firm's external environment (see Figure 
2). Despite this disparity, there is an overlap between the two research streams, as studies in one stream often control for environmental factors studied in the other stream.

Research on the multibusiness firm's CHQ has addressed whether and how a firm's industry and product markets affect the CHQ (e.g., Adner \& Helfat, 2003; Chandler, 1991; Greenwood, 1964; Greenwood, Hinings, \& Brown, 1990; Porter, 1987; Raynor \& Bower, 2001; Yavitz \& Newman, 1982). Of importance are diverse features, such as industry attractiveness (Porter, 1987), industry transformations (Chandler, 1991), market turbulence (Raynor \& Bower, 2001), the degree of regulation (Russo, 1992), and - a notable addition from the other research stream - the internationalization of markets and industries (Birkinshaw et al., 2006). For example, Chandler (1991) finds that firms in industries characterized by high capital intensity and high technological complexity require long-term investments in product-specific skills, which in turn demand a strategic-planning (or strategic-control) style at the CHQ. On the other hand, firms competing in industries with relatively low costs of capital and low complexity of specific skills find that "synergies from R\&D, production and distribution are limited" (Chandler, 1991, p. 49). For these firms, a financial-control style is advantageous. Further, Raynor and Bower (2001) suggest that the CHQ should provide more guidance in turbulent markets. While this supports the notion that the CHQ's role and integrating mechanisms in a multibusiness firm generally depend on the firm's industry, there is less knowledge about relationships for individual CHQ activities, such as corporate planning (Greenwood, 1964).

Research on the multinational firm suggests that the geographic context matters for the CHQ's characteristics and the CHQ-operating unit relationships. Scholars have, for example, focused on the effects of macroeconomic factors, such as shocks related to foreign currencies (Jacque \& Vaaler, 2001), unemployment, and taxes (Laamanen et al., 2012) on CHQ design and 
location. Another important, albeit still small, sub-strand of the literature examines international differences between CHQs, arguing that the institutional, legal, and cultural heritage of the country of domicile will have significant effects on the CHQ (Collis et al., 2007, 2012; Schollhammer, 1971). In this vein, a notable contribution of the literature on the multinational firm's CHQ is the geographic diversity of samples within and across studies, by examining multinational firms located in, for example, Europe and the US (Schollhammer, 1971); Japan (Chan \& Makino, 2007; Song, 2002; Tan \& Vertinsky, 1996); Sweden (Birkinshaw et al., 2006); Australia, Canada, and the UK (Bouquet \& Birkinshaw, 2008); the Netherlands (Baaij, Mom, Van Den Bosch, \& Volberda, 2012a); and the US, the UK, Germany, Chile, France, and the Netherlands (Collis et al., 2012). While this variance complicates the comparison of the findings across studies, cumulative research leads to the conclusion that there are significant international differences in the design of the CHQ and that the macroeconomic environment affects the (re)location decisions regarding the multinational firm's CHQ.

Other CHQ studies consider common features in the firm's environment, such as the CHQ and firm agglomeration, the political regime, and external stakeholders (Birkinshaw et al., 2006; Crilly, 2011). Importantly, a recent focus on stakeholders has expanded our knowledge of the influence of other environmental factors on the CHQ. For instance, Birkinshaw et al.'s (2006) study of a large-scale sample of Swedish multinational firms provides evidence that firms primarily relocate their CHQ in response to the demands of external stakeholders, especially international financial markets and shareholders. In another extension to other stakeholders, Crilly (2011) analyzes overseas subsidiaries and finds, among other things, that "although theory emphasizes external stakeholders' control over resources, internal control through the corporate parent can crowd out the voices of local stakeholders" (p. 694). While these studies suggest that 
diverse stakeholders, not just shareholders, matter for the CHQ and CHQ-operating unit relationships, insights remain sparse.

In sum, previous research suggests that the firm's industry and geographic contexts are important in shaping the CHQ's characteristics. Resources required for success in the multibusiness firm's industry sector will affect the CHQ functions. For example, the CHQ's centralized procurement and supply chain management may be more valuable for consumer goods firms than for financial services firms. Following transaction cost logic, the industry sector will determine which activities should be performed inside the firm, or outside in a market (Teece, 1980; Williamson, 1975), affecting, for example, the outsourcing of shared services functions. Research on the multinational firm builds upon similar resource-based and transaction cost rationales when exploring how different geographies affect the decision to perform specific CHQ roles. For example, the role of the CHQ in providing capital for the businesses may be more pronounced in firms located in emerging economies with underdeveloped capital markets and/or lacking other institutions (Khanna \& Palepu, 2000). Since geography determines the efficiency of domestic product and factor markets, research on the multimarket firm's CHQ needs to recognize these differences in the environmental context.

\section{The CHQ's Organizational Context}

Nearly all studies on the CHQ argue that its design will depend on how the multimarket firm creates value across its various markets. In particular, these studies adopt the contingency perspective that the characteristics of an effective CHQ will depend on the firm's strategy and its consequent organization structure. As Figure 2 illustrates, this leads to an emphasis on corporate 
strategy and structure in research on the multibusiness firm's CHQ, but on global strategy and structure in research on the multinational firm's CHQ.

In the multibusiness literature, there is widespread agreement that the CHQ's roles, capabilities, design, and integrating mechanisms need to be aligned with the firm's corporate strategy and structure (Berg, 1969, 1977; Hill et al., 1992; Leontiades \& Tezel, 1981; Raynor \& Bower, 2001; Teece, 1982; Van Oijen \& Douma, 2000). While a few studies have addressed "exotic" topics, such as why the architecture of a CHQ building should reflect the firm's mission (Thurm, 2005), the dominant theme in this work relates to the fit between a firm's diversification strategy (which is typically viewed as a proxy of its corporate strategy) and the CHQ. A variety of detailed case studies and large-scale quantitative surveys provide evidence that the CHQ must "fit" with the extent and type of the firm's product diversification, especially in terms of related versus unrelated diversification (e.g., Collis et al., 2007; Hansen \& Peytz, 1991; Hill et al., 1992; Hoskisson, 1987; Hungenberg, 1993; Kono, 1999; Porter, 1987). Indeed, an empirical analysis by Collis et al. (2007) confirms the recurrent claims in previous studies that corporate strategy is an important determinant of the CHQ's role and size.

Few studies go beyond these general findings to investigate corporate strategy's effect on specific CHQ activities (Leontiades \& Tezel, 1981; Van Oijen \& Douma, 2000). Van Oijen and Douma (2000) find that while high-performing multibusiness firms align certain CHQ activities (planning, evaluation, selection, motivation, and support) with their diversification strategies, this is not true of all activities (coordination, job rotation). In their survey of chief planning officers, Leontiades and Tezel (1981) show that the planning efforts of the CHQ increase as firms diversify, supporting the link between corporate strategy and the prevalence of certain CHQ activities. 
One shortcoming of this multibusiness firm literature lies in the difficulty with portraying corporate strategy accurately. While part of this challenge relates to measurement problems, it also reflects the complexity of a firm's corporate strategy. Interestingly, Raynor and Bower (2001) suggest that "diversification strategy can be a mixture of related and unrelated elements; companies can pursue varying degrees of relatedness between divisions" (p. 98). Pursuit of this strategy demands that the CHQ takes on different roles simultaneously.

The multibusiness firm's corporate structure also has implications for the firm's CHQ. Ever since Chandler (1962) suggested that the creation of the CHQ (and of divisional headquarters (DHQ)) is contingent upon the adoption of the M-form organization, most studies have found that aligning structure with corporate strategy is critical for superior firm performance and that the CHQ characteristics will follow in turn (e.g., Collis et al., 2007; 2012; Hill et al., 1992; Hill \& Hoskisson, 1987; Hoskisson, 1987; Markides \& Williamson, 1996). Hoskisson (1987), for example, conducted a longitudinal study of 62 US industrial firms and reveals that the implementation of the M-form organization enhances firm performance of unrelated diversifiers, while it decreases the performance of vertical integrators. Similarly, Hill et al. (1992) analyze 184 Fortune 1,000 firms and find that the fit between a firm's diversification strategy, its organizational structure, and its CHQ control systems leads to superior performance. Although Hitt and Ireland (1986) find that the CHQ's effect on firm performance does not vary by type of organizational structure, the majority of studies supports a contingency perspective on the role of the CHQ in the multibusiness firm.

These insights have been extended by the consideration of novel organizational forms, such as multiunit firms (Garvin \& Levesque, 2008) and professional partnerships (" $\mathrm{P}^{2}$-form”) (Greenwood et al., 1990), as well as emerging theoretical perspectives on the CHQ-structure 
alignment. Greenwood et al. (1990), for example, studied large US accounting firms and find that the CHQ in a professional partnership differs from that of a firm with an M-form or a holding-company organizational design along three control dimensions (strategic, marketfinancial, and operating control). Other scholars incorporate novel perspectives, such as the fit of distinct CHQ dynamic capabilities with Mintzberg's (1979) design parameters (Bowman \& Ambrosini, 2003). More generally, Goold and Campbell (2002b) suggest that modern organizational arrangements complicate the clear distinction between operating units and centralized administrative units due to an additional headquarters layer.

In contrast to the rich literature on corporate strategy and structure's influence on the CHQ, less research has examined the effect of global strategy and structure on the CHQ. It is widely acknowledged that since "structure follows strategy" in both multinational and multibusiness firms, a multinational's overall organizational design will depend on its global strategy (Bartlett \& Ghoshal, 1989). Thus, a centralized structure will support a "global" strategy and should have a different CHQ than the more decentralized structure of a multinational firm pursuing a "multidomestic" strategy. However, the particulars of those differences are not clear (Bartlett \& Ghoshal, 1989). In one of the few studies that have explored the effect of a firm's international strategy on the CHQ's design, Collis et al. (2012) find that the CHQ size is positively related to the firm's geographic scope, which they measure as the number of continents on which the firm is active. Even though the CHQ becomes less interventionist in subsidiary activities as its scope grows, the information-processing requirements associated with the increasing complexity of operating across more diverse geographies appear to require a larger CHQ. Similarly, as the multinational firm becomes more involved in subsidiary 
activities - a shift that reflects a more coordinated global strategy - the size of the CHQ increases.

Research on the influence of the multinational firm's structure on the CHQ has often centered on novel network designs (e.g., Ciabuschi, Dellestrand, \& Martín, 2011; Foss, Foss, \& Nell, 2012; Howard, 1991; Nohria \& Ghoshal, 1997; Rugman \& Verbeke, 2001). For example, Foss et al. (2012) argue that a change from hierarchical organizational designs to network structures increase the frequency of CHQ interventions. This literature makes an important contribution with the analysis of the effect of the network structure's characteristics on the CHQ's roles. One example is Ciabuschi et al.'s (2011) study of innovation projects in subsidiaries of multinational firms located in 14 countries. Challenging the network perspective and highlighting the vital role of the CHQ in the multinational, they find that the CHQ's involvement in the innovation development process enhances the subsidiary competences, whereas the subsidiary's internal embeddedness does not.

Research on the multinational firm's CHQ has also contributed to our knowledge about the role of subordinate unit headquarters, such as regional headquarters (RHQ) and their relationships with the CHQ (Alfoldi, Clegg, \& McGaughey, 2012; Mahnke, Ambos, Nell, \& Hobdari, 2012; Ohmae, 1989; Parks, 1974), which we identified as lacking in the multibusiness firm literature. Mahnke et al. (2012), for example, highlight the importance of the CHQ-RHQ relationship. They analyzed survey data from 42 RHQs in five countries, and find that the RHQ serves as a bridge between the firm's operating units and its CHQ, as well as that the RHQ's autonomy and signaling behavior affect the RHQ's influence on the firm's corporate strategy. Since many contemporary firms bundle certain product-market and/or country activities in RHQs and/or DHQs, this is a promising area for research in both streams. 
Studies from both literatures have asserted that several common organizational factors affect the CHQ's characteristics, such as firm size (Bazzaz \& Grinyer, 1981; Berger \& Ofek, 1995; Collis et al., 2007; Leontiades \& Tezel, 1981), work environment (Thurm, 2005), and performance (Stubbart, 1982). The findings consistently confirm that firm size affects the CHQ's design (Bazzaz \& Grinyer, 1981; Collis et al., 2007). Collis et al. (2007), for example, show that firm size increases information-processing demands and, thereby, the size of the CHQ, particularly the obligatory or core functions. Similarly, Bazzaz and Grinyer (1981) find a positive correlation between firm size and the number of staff in the CHQ's planning subunit. Although Leontiades and Tezel (1981) reveal that the intensity of corporate planning at the CHQ does not depend on a firm's size, the increase in organizational complexity that comes with expanded size appears to influence not only obligatory $\mathrm{CHQ}$ functions, but also value-adding and discretionary activities, such as strategic planning.

Research on the multibusiness firm also suggests that the firm's corporate governance can have a profound influence on the CHQ. In this vein, scholars have analyzed the effects of various types of shareholder ownership on the design of the CHQ (Alexander, 1992; Birkinshaw et al., 2006; Collis et al., 2007, 2012; Ferlie \& Pettigrew, 1996; Scharfstein, 1998). In a recent study, Collis et al. (2007) argue that the governance system affects the size of the CHQ and reveal that government-owned firms have larger CHQs than firms with other types of ownership. However, their study does not confirm that privately owned firms have smaller CHQs than public firms. Similarly, in a longitudinal study of 165 US conglomerates, Scharfstein (1998) identifies agency problems between investors and the $\mathrm{CHQ}$, especially in firms in which management holds a small equity stake, which might lead to larger CHQs than is optimal. 
Beyond these governance-related studies, there is surprisingly little knowledge regarding the effect of the CEO, or the top management team (TMT), on the CHQ, with only two studies tangentially addressing aspects of this issue (Campbell et al., 2012; Law et al., 2009). Given the management literature's awareness of the importance of individual "dominant logics" for organizational decisions, this is surprising. Given that the strategies of senior executives are partially executed through the CHQ's design, and since the TMT is at least partly located at the $\mathrm{CHQ}$, this gap in our knowledge is an unexpected finding.

In sum, in addition to the insights into the determinants of CHQ characteristics identified in the two streams, it is important to note how the contribution of one stream may help to overcome weaknesses in the other. While the single-most recognized finding in research on the multibusiness firm's CHQ is the difference between related and unrelated (conglomerate) diversification strategy, a detailed examination of the effect that the differences in international strategy-even between the extreme characterizations of "global" and "multidomestic" strategies - have on the CHQ is missing in multinational firm research. Given that CHQ size and the nature of the corporate control system differs fundamentally between the types of corporate strategy (Collis \& Montgomery, 1998; Goold \& Campbell, 1987), it is important to understand how the choice of international strategy influences CHQ characteristics in the multinational firm.

Similarly, extant research on the multinational firm's CHQ that considers the heterogeneity of the international subsidiaries' markets a surrogate of the global strategy, simply examines the number of countries or regions in which the entity operates (e.g., Collis et al., 2012), or, sometimes, the geographic distance from the CHQ. To offer more insight into the suitability of the CHQ's roles and design for different global strategies, scholars must better account for the varieties of strategies that create value across geographies, perhaps by 
considering the heterogeneity or relatedness of the firm's product offerings between geographic markets (Collis, 2014). Moreover, since research on the multibusiness firm's CHQ reveals the influence of the firm's governance structure on the CHQ's roles and design, and given that there are substantial differences in the governance systems across geographies (Collis et al., 2007), this factor needs to be considered in research on the multinational firm's CHQ.

Conversely, when accounting for corporate strategy, studies of the multibusiness firm's CHQ have relied on narrow conceptualizations of the level of portfolio diversification and relatedness. Typically, these studies have used measures based on Standard Industry Classification (SIC) codes. To more accurately capture the suitability of the CHQ's roles and design for a given business portfolio, future studies might draw upon the multidimensional frameworks found in the multinational firm literature, for example, Ghemawat's (2001) CAGE framework, as well as account for additional aspects, such as the differences in the dominant logics or industry recipes. Indeed, research deploying new measures of relatedness based on elements such as knowledge assets (Tanriverdi \& Venkatraman, 2005) may contribute to our understanding of the rationale for specific CHQ roles and activities, such as the coordination across businesses. Moreover, as the structural solutions of large contemporary corporations become increasingly complex, research into the multibusiness firm's CHQ can benefit from insights into how the design of the multinational firm's CHQ is affected by other headquarters units, such as RHQs.

\section{The CHQ's Common Challenge-Integrating Differentiated Operating Units}

At the heart of CHQ research is the fundamental challenge faced by both the multibusiness and multinational firm - achieving a balance between the differentiation and 
integration of the firm's operating units (Lawrence \& Lorsch, 1967). Accordingly, a substantial amount of research in the two streams focuses on the extent of the differentiation between the firm's operating units, including its effect on CHQ-operating unit relationships, and on the integrating processes and systems the CHQ employs. Because of the two streams' focus on either the firm's product divisions, or the firm's international subsidiaries, the conversations have emerged separately and have examined characteristics that are unique to either the product or the geographic operating units (see Figure 2).

The multibusiness firm literature has largely taken a top-down, "one size fits all" perspective when considering the differentiation-integration challenge, in the belief that the CHQ creates value through its influence on the firm's product divisions. Scholars agree that the CHQ's roles and integrating mechanisms should be aligned with the business units' specific characteristics (Goold, 1996b; Govindarajan, 1988; Semadeni \& Cannella Jr., 2011). The distinct characteristics of the firm's product divisions/business units have therefore long been a subject of inquiry and several product-division characteristics have been found to matter for the CHQproduct division relationship, such as the business units' needs (Campbell, Goold, \& Alexander, 1995a); its bargaining power relative to the CEO (Scharfstein \& Stein, 2000); investment prospects (Scharfstein, 1998); maturity (Goold, 1996b); the similarity of the products, technologies, and customers (Young, 1998b); the strategic mission and competitive strategy (Gupta, 1987); the size (Russo, 1992; Semadeni \& Cannella Jr., 2011); the ownership structure (Semadeni \& Cannella Jr., 2011); as well as the relatedness of the product divisions to each other, which the firm's corporate strategy represents.

The various integrating mechanisms that multibusiness scholars have examined, focus on the CHQ's (formal) control mechanisms, informed by agency-theoretic foundations, and include 
the extent and type of control and monitoring exercised by the CHQ (Balderston, 1962; Chandler, 1991; Chen et al., 2009; Crilly, 2011; Goold \& Campbell, 1987; Govindarajan, 1988; Greenwood et al., 1990; Hill et al., 1992; Jacque \& Vaaler, 2001; Roth \& Nigh, 1992; Semadeni \& Cannella Jr., 2011), the extent of the CHQ's planning influence (Berg, 1969; Goold \& Campbell, 1987), and the CHQ's budgeting procedures (Govindarajan, 1988). For example, Greenwood et al. (1990) advance a configuration logic and argue that, depending on the firm's organization structure, "ideal" types of control do exist. With regard to the extent of the influence that the CHQ should exercise, Semadeni and Cannella Jr. (2011) draw upon agency and transaction cost logics in a study of 142 spin-offs from listed US firm between 1986 and 1997 to identify an optimal level of CHQ involvement in the product divisions. While some CHQ influence may be beneficial because it ensures that divisions draw on the CHQ's specialized expertise, they argue that too much CHQ influence may restrict divisional autonomy and, thus, their adaptability.

This illustrates one of the key conundrums in the CHQ's activities. On the one hand, the CHQ should delegate decisions related to the competitive strategies to the divisions; on the other hand, the CHQ should restrict the division's decision-making authority to prevent conflicts between these multimarket strategies and to exploit the potential synergies between the divisions. Sengul and Gimeno (2013) put forward the idea of "constrained delegation," and show that organizational choices pertaining to CHQ-operating units relationships are endogenous to the competitive context. Based on an empirical analysis of the subsidiaries of groups operating in France between 1997 and 2004, they find that although firms competing in multiple industries delegate most business-level decisions to their operating units, they adjust to multimarket competition by constraining the scope of their operating units' decision rights and their available 
resources. This finding stresses the impact of the CHQ's corporate portfolio perspective across multiple markets, as opposed to the operating units' single market perspective.

Among the most prominent contributions to research on the use of integrating mechanisms, such as control and planning (Berg, 1969; Chandler, 1991; Goold \& Campbell, 1987), is Goold and Campbell's (1987) notion of strategic management styles, which was later renamed "parenting styles" (Goold et al., 1994). Based on findings from a field study of 16 UK firms, they highlight the extent of control influence and strategic-planning influence as the CHQ's two central integrating mechanisms. Moreover, they identify eight different management styles, finding that firms most frequently adopt the strategic-planning, strategic-control, and financial-control styles. However, building upon a (implicit) contingency line of argument, they find that none of these three styles is superior; rather, their value depends on the firm's strategic and environmental context.

Despite providing these insights into the CHQ-product division relationship, research in this stream focuses on the CHQ's authority and top-down integration mechanisms in managing the firm's product divisions. Indeed, relatively few studies are concerned with other processes involved in the relationship between the CHQ and the business units (Goold, 1996b; Gupta, 1987; Joseph \& Ocasio, 2012; MacMillan \& Meshulach, 1983). Among the notable exceptions is Gupta's (1987) survey of business-unit general managers in Fortune 500 firms. Gupta finds that CHQ-business relations characterized by openness and subjectivity in performance assessments enhance businesses pursuing a competitive strategy of differentiation, while they negatively affect businesses pursuing a cost-leadership competitive strategy. In an inductive study of General Electric's governance system from 1951 to 2001, Joseph and Ocasio (2012) identify "collective vertical interactions between the corporate office and business units through cross- 
level channels" (p. 633) as an unexplored, but relevant, aspect of the multidivisional firm. Given the importance of informal integrating mechanisms and more complex control configurations, research along these lines may improve our understanding of the relationships between the CHQ and product divisions.

In contrast, the multinational firm literature has largely contributed a bottom-up approach by highlighting the role played by, and the perspective of, the international subsidiaries in the CHQ-subsidiary relationships. Early studies on the multinational firm suggested that the role of the CHQ depended on the maturity of the international subsidiaries (Rutenberg, 1969), and that a shift towards multinational operations led to changes in the firm's CHQ reporting and control systems (McInnes, 1971). Later research confirmed that several characteristics of a firm's international units affect the CHQ and the CHQ-subsidiary relationships (e.g., Ambos et al., 2010; Birkinshaw \& Hood, 2001; Crilly, 2011; Foss et al., 2012; Law et al., 2009; Roth \& Nigh, 1992; Takeuchi, Shay, \& Li, 2008; Tomassen, Benito, \& Lunnan, 2012; Vahlne, Schweizer, \& Johanson, 2012), including the international subsidiaries' local networks (Vahlne et al., 2012), local stakeholders (Crilly, 2011), resource dependence, salience to the corporation, managers' nationalities (Martinez \& Ricks, 1989), initiatives and autonomy (Ambos et al., 2010), internal and external embeddedness (Ciabuschi, Dellestrand, et al., 2011; Nell \& Ambos, 2013), ownership arrangements and choices (Chan \& Makino, 2007; Martinez \& Ricks, 1989), and expatriate managers' decision-making autonomy (Takeuchi et al., 2008). For example, in a survey of Mexican affiliates of a US-based multinational firm, Martinez and Ricks (1989) find that the CHQ's influence is positively related to the affiliate's dependence on CHQ resources. Not surprisingly, most of these studies implicitly or explicitly confirm that geographic scope is a key feature, determining the extent of the differentiation in the portfolio of subsidiaries. 
In much of this research, the corporation is viewed as a differentiated network consisting of relatively independent nodes of international subsidiaries, with the CHQ serving as a network switch that coordinates the horizontal linkages between subsidiaries. Studies that build on this insight contribute to our knowledge about integrating mechanisms used by the CHQ in at least in two important ways. First, even though scholars in this stream have examined formal integrating mechanisms, such as control and coordination (e.g., Chen et al., 2009; Roth \& Nigh, 1992), a key contribution stems from drawing attention to the informal mechanisms that shape the CHQsubsidiary relationship (Martinez \& Jarillo, 1989; O'Donnell, 2000). Such mechanisms include socialization, for example, through corporate HR-managed personnel transfers and training, and shared identity/corporate purpose initiatives that facilitate normative integration (Foss et al., 2012; Nohria \& Ghoshal, 1994; Ohmae, 1989), and procedural justice (Foss et al., 2012; Kim \& Mauborgne, 1991). Notably, few studies have investigated the simultaneous usage of formal and informal integrating mechanisms. A prominent contribution is Nohria and Ghoshal's (1994) study of multinational firms, in which the authors suggest two different approaches to effectively manage the CHQ-subsidiary relationships: "differentiated fit" (the adjustment of the formal structure of the CHQ-subsidiary relationships to the subsidiaries' contexts) and "shared values." They reveal that while these two approaches are alternatives, firms that implement both simultaneously have a relatively higher performance than other firms.

Second, the multinational firm literature has stressed that integrating mechanisms used by the CHQ may differ within the same firm (Gupta \& Govindarajan, 1991; Nohria \& Ghoshal, 1994). Gupta and Govindarajan (1991), for example, suggest that the nature of corporate control varies across subsidiaries, depending on the subsidiary's usage and provision of knowledge. Specifically, they argue that the integrating mechanisms will be more complex for subsidiaries 
that are "integrated players" and characterized by high knowledge in- and outflows, and less complex for "local innovators" with low knowledge in- and outflows. Thus, the relationship between a subsidiary and the CHQ not only depends on the subsidiary's context, but is also affected by its (strategic) importance for the overall firm. This notion of treating the integration of operating units differently is, by and large, missing in the multibusiness literature.

In sum, our review reveals that scholars in the two research streams have relied on opposing premises regarding how firms deal with the CHQ's fundamental challenge of integrating differentiated operating units: A top-down perspective ("the CHQ is in control") is found in the multibusiness firm literature along with the view that the influence of the CHQ on the business units is largely positive ("good CHQ interventions") as a way to realize synergy, while a bottom-up view ("the subsidiaries determine the fortune of the overall firm") and a sense that the CHQ can harm international subsidiaries ("bad CHQ interventions") because it limits their discretion to adapt and compete locally, is evident in the multinational literature. Even though recent studies have started to resolve this tension by revealing that there is an optimal level of CHQ involvement (Semadeni \& Cannella Jr., 2011; Walter, Heinrichs, \& Walter, 2014), research needs to incorporate both premises to resolve the differentiation-integration challenge confronting the CHQ.

A side-by-side comparison of the two streams suggests that research on the multibusiness firm's CHQ is likely to benefit from considering the horizontal integrating mechanisms — such as socialization and shared values - discussed in the multinational firm literature. Indeed, recent studies indicate that value creation through collaboration across business units and through product divisions' contributions to corporate initiatives requires a commitment from the product divisions that may not be achievable by solely relying on formal integrating mechanisms, such as 
hierarchical structure and processes (e.g., Martin \& Eisenhardt, 2010). Analogous to multinational firm research, studies that examine the product divisions' perspective and their influence on the CHQ-product division relationship may uncover explanations for the various integrating mechanisms' effectiveness.

Conversely, the rich literature on the multibusiness firm's solutions for the agency problems arising when the CHQ delegates decision making to product divisions may stimulate research on the multinational firm's CHQ. Since multinational firms increasingly require coordination and collaboration across regions, vertical CHQ integrating mechanisms, including formalization and control, may become more critical.

Beyond informing each stream, the collective literature's contributions facilitate analyses of the multimarket firm's CHQ-integrating mechanisms and parenting styles in respect of a portfolio of diverse product and geographic units. Most studies have considered the characteristics of the operating units, on which the CHQ integrating mechanisms depend, at the level of the overall portfolio and not of the individual operating unit. Hence, an important shortcoming of the literature, particularly for the multibusiness firm's CHQ, is that it does not account for such heterogeneity and often (over)simplifies CHQ-operating unit relationships as being the same for all units. Given the differences between product and geographic units, future studies should consider complex relationship configurations that involve multiple mechanisms, as well as corresponding organizational designs, such as matrix organizations, in which the CHQ plays a more nuanced role. 


\section{The CHQ's Outcomes}

The underlying question of how the CHQ creates value across markets-whether products or geographies - is common to both research streams. It therefore follows that the effect of choices concerning the CHQ's characteristics and behaviors on various outcomes is an important topic for both research streams. Studies on the multibusiness firm's CHQ focus more on CHQ-related outcomes, while research on multinationals' CHQ typically concerns outcomes in their international subsidiaries. Naturally, studies in both streams are concerned with the CHQ's contribution to firm-level financial performance, including the CHQ's effect on several intermediate outcomes, such as innovation (see Figure 2).

Studies on the multibusiness firm's CHQ examine the determinants of various CHQ/corporate-level outcomes, such as the extent of corporate entrepreneurship (Batten, 2002), strategic focus (Kaplan \& Norton, 2005), coherent corporate strategies (Goold, 1996a), and the success of the corporate initiative process (Darragh \& Campbell, 2001). In addition, scholars have examined the overall costs and benefits of the CHQ (Collis \& Montgomery, 1997; Pettifer, 1998; Rutenberg, 1969) and CHQ-level changes over time (Ferlie \& Pettigrew, 1996). Collis and Montgomery (1997) summarize prior studies' findings and reveal that the costs of the CHQ range from 0.66 to $0.75 \%$ of the firm's assets, or about $1 \%$ of revenue. As a minimum benchmark, they suggest comparing CHQ costs with the fees that mutual funds charge, which at least provide investors with asset diversification.

While the CHQ costs can be fairly easily assessed, measuring the CHQ's benefits is much more complicated, because the CHQ only plays a part in the overall corporate performance. Scholars from both research streams have typically studied CHQ effectiveness by means of surveys that capture self-reported performance measures. Such surveys have analyzed the 
multibusiness firm's CHQ performance as perceived by the CHQ executives (Collis et al., 2007); the bargaining, monitoring, information, and bonding costs of governing international subsidiaries as assessed by the senior managers (Tomassen et al., 2012); and the CHQ value added as evaluated by the subsidiary managers (Nell \& Ambos, 2013). Nell and Ambos (2013), for example, find that the CHQ's external embeddedness, as perceived by manufacturing subsidiaries' general managers, is positively related to the CHQ value added, because that embeddedness may enhance the CHQ's knowledge and facilitate the building of domain expertise. Unfortunately, while there is some evidence that specific features of the CHQ, such as its size, do affect its overall effectiveness, the measures used are hardly robust or accurate representations of CHQ performance.

While research in both streams has analyzed the CHQ's effect on operating unit outcomes, the study of the multinational firm's CHQ has predominantly informed this area. Perhaps due to the other stream's top-down approach, research analyzing whether and how the multibusiness firm's CHQ affects product-division performance is limited (Gupta, 1987; Hungenberg, 1993; Russo, 1992). Overall, there is need for more research on this issue, especially because the CHQ's value contribution in the diversified firm is only due to the improved operating-unit performance (Porter, 1987).

Studies of the multinational firm's CHQ have frequently examined outcomes related either exclusively to international subsidiaries, or to the CHQ-subsidiary relationship. Scholars have considered the effectiveness of the subsidiary or CHQ-subsidiary relationship (Roth \& Nigh, 1992; Roth \& O'Donnell, 1996), the CHQ's attention to subsidiaries (Bouquet \& Birkinshaw, 2008), the CHQ's influence on subsidiaries (Martinez \& Ricks, 1989), and CHQ intervention as perceived by subsidiaries (Foss et al., 2012). Notable is the variety of process 
outcomes in this vein, including the early recognition of investment opportunities (Tan \& Vertinsky, 1996), the subsidiary's innovation process (Ciabuschi, Forsgren, et al., 2011), subsidiaries' innovation-related competencies (Ciabuschi, Dellestrand, et al., 2011), and localization success (the extent to which local employees replace expatriate managers) (Law et al., 2009). As these studies consistently find that the CHQ (positively or negatively) affects international subsidiaries' performance, they may stimulate analogous research on the multibusiness firm's CHQ, especially because they draw attention to the CHQ's potentially harmful influence on the operating units' performance.

Both research streams have studied the CHQ's effect on firm-level outcomes, since demonstrating the CHQ's contribution to firm-level value creation is a frequent motivation of research in this area, especially on the multibusiness firm (e.g., Adner \& Helfat, 2003; Collis \& Montgomery, 1998; Darragh \& Campbell, 2001; Goold \& Campbell, 1987; Hungenberg, 1993; Porter, 1987). These studies usually rely on accounting-based measures of firm performance, including return on assets (Adner \& Helfat, 2003; Berger \& Ofek, 1995; Hill et al., 1992; Hoskisson, 1987; Van Oijen \& Douma, 2000), return on equity (Russo, 1992; Van Oijen \& Douma, 2000), and return on sales (Markides \& Williamson, 1996; Van Oijen \& Douma, 2000). To a lesser extent, they also rely on market-based measures, such as shareholder returns (Collis et al., 2007; Hitt \& Ireland, 1986), and various stock market multiples (Berger \& Ofek, 1995). The particular performance effect studied depends on the CHQ-related aspect of interest. For example, Markides and Williamson (1996) argue that competences to develop strategic assets faster and more efficiently than competitors leads to superior performance.

Unfortunately, studies that explore the CHQ's direct effect on firm performance reveal no significant association, perhaps because the effect on overall corporate performance is small and 
influenced by many other variables and multiple interdependent contingencies (e.g., Collis et al., 2007; Hoskisson, 1987; Markides \& Williamson, 1994). While there is some empirical support for the argument that a fit or alignment between the CHQ and the corporate (diversification) strategy (e.g., Collis et al., 2007; Markides \& Williamson, 1994; Van Oijen \& Douma, 2000), and/or the organizational structure (e.g., Hill et al., 1992; Hitt \& Ireland, 1986; Hoskisson, 1987; Markides \& Williamson, 1996) and/or the environment (Adner \& Helfat, 2003) results in superior firm performance, causal relationships between specific CHQ characteristics and corporate performance can be difficult to identify. The obvious example is that while larger CHQs are associated with higher corporate performance, the direction of causation is unproven - a larger CHQ might create more value, or superior performance could be dissipated in CHQ slack (Collis et al., 2007). An alternative approach, which has received some support in previous empirical studies, is to evaluate the intermediate outcomes that the CHQ impacts directly, such as innovation (Birkinshaw \& Hood, 2001), or sequential foreign investment decisions (Song, 2002).

In sum, while there have been valuable contributions from both streams, our overall understanding regarding the extent to which and how the CHQ affects various outcomes is fairly limited. Remarkably, even though this research now has a history of more than half a centurywe still have not yet conclusively demonstrated whether or how the CHQ benefits the firm. Considering the sometimes quite substantial costs of the CHQ, there needs to be much more research in both streams that focuses on the CHQ value added, or value destroyed, as well as on its individual corporate functions. Since these effects typically become visible through changes in the firm's operating-unit performance (Porter, 1987), the initial multinational firm research may serve as the blueprint for similar studies on the multibusiness firm's CHQ. 


\section{FUNDAMENTAL INQUIRIES FOR FUTURE CHQ RESEARCH}

Our assessment of the two research streams reveals an extensive body of knowledge about the CHQ. The side-by-side comparison of the contributions from the two research streams portrayed in Figure 2, and elaborated in the preceding section, facilitates fertilization across the two research streams. We argued that because the two streams deal with the same fundamental rationale for, and challenges facing, the $\mathrm{CHQ}$, bringing them together benefits our understanding of the CHQ in three ways. First, the two streams contribute different, but complementary, perspectives that challenge conventional assumptions and offer new insights for the other stream. Second, each stream highlights certain aspects of the CHQ that the other should consider to develop a more complete picture and resolve inconsistent findings. Third, the two streams contribute different conceptualizations and measurement approaches that may improve research in the other stream.

Beyond the cross-fertilization benefits, combining the two research streams provides the basis for identifying fundamental lines of inquiry, which we believe should guide future CHQ research efforts both within and across the two streams. Indeed, our review also reveals that knowledge about the CHQ has become increasingly fragmented, for example, by becoming overly concerned with idiosyncratic issues, such as the best measure of technological relatedness in the multibusiness firm, and, to a certain extent, no longer focuses on the critical issues pertaining to the CHQ. In trying to address a specific gap in the literature, studies in the two streams risk losing sight of the forest for the trees and, thereby, diminish their value for our cumulative knowledge of the phenomenon. If we refocus on the underlying factors that determine the CHQ's characteristics and functioning, we can facilitate the integration of 
advances in theory and their empirical validation. Hence, although we do not promote full integration of the two streams, we do advocate adopting a consistent perspective on the CHQ in the multimarket firm that identifies the underlying causes and relationships across markets, rather than the particulars of businesses and geographies.

Consequently, while many exciting research opportunities lie ahead in the two individual research streams, based on our review of their insights, we specifically encourage scholars to focus their attention on four fundamental inquiries about the CHQ in the multimarket firm: (1) the CHQ's scope; (2) the CHQ's relations; (3) the CHQ's functioning; and (4) the CHQ's raison d'être. In the following, we elaborate these four inquiries with some of the exemplary research directions, which are listed in Table 2.

Insert Table 2 about here

\section{The CHQ's Scope}

Despite the substantial amount of research on the CHQ in the two streams, we still have surprisingly few insights into the CHQ's defining features and boundaries - the scope of this research's central phenomenon. While Chandler's (1962) original work, as well as other conceptual and field-based studies (e.g., Chandler, 1991; Foss, 1997; Goold \& Campbell, 1987; Markides, 2002), contributed to an initial understanding of the CHQ, often in the context of an industrial multibusiness firm, many other studies have built on the rather basic (implicit) assumptions that the CHQ is primarily defined by its structural separation from the operating units, and that it is a somewhat comparable and stable unit across settings and time.

Several observations, however, suggest reconsidering our conventional wisdom about the CHQ. First, changes in the nature of the firm over time, such as the emergence of new 
organizational designs (e.g., Chandler, 1962; Fligstein, 1985; Foss et al., 2012), the "flattening of the firm" (Rajan \& Wulf, 2006) and the "decentering of the global firm" (Desai, 2009), as well as the increasing importance of technology, indicate that the nature of the CHQ has also changed and that its roles need to be aligned. Second, perhaps as consequence of these developments, scholars have noticed the disaggregation of the CHQ into smaller components (Desai, 2009), such as the dispersion of certain activities and roles of the multinational firm's CHQ across multiple locations (and units) (Baaij et al., 2012b), or the implementation of a "dual headquarters" strategy (DuBrule et al., 2010). For example, Desai (2009) conceptualizes the multinational firm's CHQ as a legal home, a finance home, and a TMT home, which need not necessarily be bundled together at one location. Third and similarly, scholars have witnessed the "blurring" of boundaries between the corporate and operating unit levels (Goold \& Campbell, 2002b), identify novel CHQ types and designs, such as a the virtual CHQ (Birkinshaw et al., 2006), or imagine the demise of the CHQ as a discrete unit (Pasternack \& Viscio, 1998).

In light of these shortcomings and observations, we believe that there are ample opportunities for future research related to the CHQ's nature. Such knowledge is foundational to understand the roles and functioning of the CHQ, as well as for a more general theory of the multimarket firm. We encourage both conceptual and empirical work that specifies the characteristics and the (internal and external) boundaries of the CHQ in the multimarket firm. Further, the emergence of new CHQ forms, such as the virtual CHQ and the dispersed CHQ, their influence on the CHQ's boundaries, roles, and effectiveness should be studied, as prior research has largely neglected to do so. For example, research that applies an institutional lens and uses longitudinal data to study the factors in the firm's environment that give rise to specific CHQ types and roles appears particularly promising in this vein. 


\section{The CHQ's Relations}

As the CHQ is the multimarket firm's central organizational unit and serves as an intermediary between the internal and external stakeholders, managing these relationships is critical for value creation in the overall firm. On the one hand, we see a need to substantiate our knowledge of the relationship between the CHQ and the internal context, particularly the firm's operating units. While the CHQ's internal relationships with the firm's product divisions or international subsidiaries have already been a crucial concern in the two research streams, there are still important unresolved issues. Specifically, there is a need to better understand how the CHQ deals with a complex portfolio of heterogeneous business and international units, for example, accounting for bi-directional relationships and considering several organizational layers, such as RHQs and DHQs (e.g., Alfoldi et al., 2012; Mahnke et al., 2012). Research into these CHQ challenges may build on recent advances and applications of suitable theories, such as agency theory (e.g., Hoenen \& Kostova, 2014) and network theory (e.g., Vahlne et al., 2012) to account for the multidimensional nature and complexities of these relationships. Further, while particularly research on the multibusiness firm's CHQ has often relied on the assumption that the CHQ has a positive influence on the operating units, there is a need to further examine the potentially harmful role of the CHQ, as recent studies suggest (e.g., Walter et al., 2014). Moreover, given that the CHQ is not a stable entity, as discussed above, and since the composition of the firm's portfolio of product divisions and international subsidiaries normally also changes, the CHQ-operating unit relationships are likely to change, too. We therefore encourage scholars to examine how these relationships evolve over time. 
On the other hand, there is surprisingly little knowledge on the CHQ's relationships with external stakeholders. Indeed, most prior research concerns the CHQ's "internal" roles, such as corporate planning, or providing shared services, whereas it largely neglects the CHQ's "external" roles, such as the interaction with shareholders, regulatory agencies, and nongovernmental organizations. Interestingly, initial evidence supports the notion that these external parties may have a strong influence on CHQ-related decisions, such as the global financial markets on the decision to relocate the multinational firm's CHQ overseas (Birkinshaw et al., 2006) or stakeholder pressure in the home country on the decision to transfer socially irresponsible practices from the CHQ to the firm's overseas subsidiaries (Surroca, Tribo, \& Zahra, 2013). As the importance of the CHQ-external stakeholder relationships is likely to increase due to the growing importance of stakeholder groups other than the shareholders, our limited understanding of the respective CHQ roles and functions should motivate future research that examines the nature, design, and effectiveness of these relationships.

\section{The CHQ's Functioning}

A significant shortcoming of the extant literature is that, with few exceptions, it has "black boxed" the CHQ's inner workings, leaving us with very little knowledge about its structures, processes, and staffing. Given the complexity of contemporary corporate-level management, we see a need to generally improve our understanding of how the central organizational unit is organized to accomplish its respective tasks, such as managing firm-wide strategic initiatives and programs. Particular promising research directions originate from the observation that the contemporary multimarket firm's CHQ comprises an increasing variety of corporate functional units and their respective C-suite representatives (Guadalupe, Li, \& Wulf, 
2014; Kunisch, Müller-Stewens, et al., 2014; Menz, 2012). We therefore see a need to understand the prevalence, activities, structures, and effects of these CHQ subunits, because they play an important role in decision-making processes at the CHQ. In addition, as corporate strategic initiatives typically involve multiple corporate functions (Darragh \& Campbell, 2001), an understanding of cross-functional collaboration within the CHQ is critical for multimarket firms. Given the few insights into if and how collaboration occurs between corporate functions in the multimarket firm's CHQ, studies in this vein should address the coordination and communication processes that span the boundaries of corporate functions.

Moreover, we know little about the skills, career paths, and actions of those working at the CHQ, yet executives with different characteristics and responsibilities may radically affect the CHQ's roles and its integrating mechanisms. For example, CEOs with a finance background are likely to be found in firms that are more diversified and/or are more active acquirers (Jensen \& Zajac, 2004; Song, 1982) and those CHQ executives may favor financial over other types of control systems. Further, there have recently been important (new) role additions to the TMT (Menz, 2012), such as the chief strategy officer position (Menz \& Scheef, 2014), which have different task priorities and contribute different perspectives to the CHQ. Future studies should therefore examine how these executive characteristics and responsibilities affect the CHQ's functioning. In addition, research contributing to our understanding of the CHQ's staff(ing) beyond just the TMT is critical given the considerable importance, but relatively small size, of the contemporary firm's CHQ (Collis et al., 2007, 2012; Kunisch, Müller-Stewens, \& Collis, 2012). Informed by executive-selection and strategic HR research (e.g., Datta, Deepak, \& Guthrie, 1994; Rajagopalan \& Datta, 1996), and perhaps similar to Kleinbaum and Stuart's (2014) recent study, future research should develop knowledge about staff-selection criteria 
specific to the task demands of the multimarket firm's CHQ and study the interpersonal behavior and networks of CHQ staff.

\section{The CHQ's raison d'être}

Two decades ago, Rumelt, Schendel, and Teece (1994) suggested that the question "What is the function of or value added by the headquarters unit in a diversified firm?" (p. 44) is one of the four fundamental inquiries into the strategy field, but there is, as yet, no definitively satisfactory answer. Both research streams agree that the purpose of the CHQ is to achieve a “corporate advantage” (Collis \& Montgomery, 1998), "international advantage” (Collis, 2014), or a "parenting advantage" (Campbell et al., 1995a) by improving the competitive position of each operating unit of the overall firm. As described above, however, we still lack studies that provide direct evidence of whether and how the CHQ affects various performance and strategic outcomes. In light of recent debates on the role of the CHQ in contemporary organizations, in which the popular business press suggests a need to downsize CHQs in order to reduce overhead costs (Economist, 2008, 2014), academic studies on the impact of the multimarket firm's CHQ are urgently needed.

While scholars agree that the "corporate effect" accounts for a part of the variance in the overall firm's performance, we have limited knowledge of how much of that effect relates to the characteristics of the CHQ. The estimated corporate effect ranges from 4\% (McGahan \& Porter, 1997), to $2.7 \%$ for a "stable corporate effect" plus $4.6 \%$ for specific corporate management decisions (Adner \& Helfat, 2003), to somewhere between 8.6\% and 12\% (McGahan \& Porter, 2002). While these studies have primarily attributed this effect to the firm's diversification strategy, scholars have recently pointed out that these corporate effects can also stem from other 
aspects of corporate strategy and structure, including the CHQ's design and roles (Adner \& Helfat, 2003; Arrfelt, Wiseman, McNamara, \& Hult, 2014). Therefore, studies that distill the corporate effect into components will contribute to our understanding of the CHQ's impact and offer a more accurate picture of the corporate strategy's impact. Research along these lines will also help determine the analog of the corporate effect in multinational (the "global effect") and multimarket firms (the sum of corporate and global effects), attributable to these firms' CHQs. Indeed, Creal et al. (2014) identify a "multinational advantage" that is attributable to factors such as the multinational firm's equity-market segmentation and its exposure to various legal environments. Similar studies may contribute to our understanding of the CHQ's impact on multimarket firm's performance. Hence, we encourage scholars to advance measures of firm performance that fit the study's purpose (Miller, Washburn, \& Glick, 2013).

As prior research highlights, empirical difficulties abound when determining the CHQ's effect on firm performance. While studies on the multibusiness firm have found that the fit between the CHQ's role, capabilities, and design, as well as organizational or environmental contingencies (e.g., Adner \& Helfat, 2003; Collis et al., 2007; Hoskisson, 1987; Markides \& Williamson, 1994), do affect its performance, there is an urgent need for similar research on the multinational firm's CHQ and, more generally, the multimarket firm's CHQ. In order to validate our knowledge of these effects, scholars should identify multiple contingencies, such as multimarket firms in emerging markets and specific types of multimarket firms, for example, family businesses, and measure the effect of their interactions' on firm performance. The most salient need is for objective and easily applicable measures of corporate and global strategies, since neither of the two research streams has been able to accurately characterize multimarket strategies, even though both identify the importance of the CHQ's contingent design. Such 
measures could then be used to test the links between the strategy, CHQ characteristics, and overall firm performance. Finally, more adequate intermediate performance measures are needed to explain why the CHQ matters. As the CHQ usually performs multiple activities that affect a corporation's performance through, for example, specific expertise and dedicated resources, investigation of the CHQ's effect on related outcomes, such as corporate strategic change, or the success of mergers and acquisitions, will contribute to our understanding of the CHQ. In this regard, such research will help explain the existence of the multimarket firm.

\section{CONCLUSION}

CHQ research has the unique potential to contribute to our knowledge about the contemporary corporation. Nevertheless, scholars' focus on specific phenomena from different perspectives has led to CHQ research in the multibusiness and multinational firm arenas becoming increasingly disconnected. In light of the increasing fragmentation of the rich literature on the CHQ into two streams, we aimed at consolidating insights into the CHQ in the multibusiness firm and into the CHQ in the multinational firm. To achieve this, we advanced a framework that identifies, contrasts, and integrates the insights of the two research streams into a multimarket firm perspective on the CHQ. Hence, the framework facilitates the fertilization of knowledge across the two streams and, thus, future CHQ research. In addition, building upon the insights gained from the framework and review, we redirected scholarly attention to the fundamental, but common, inquiries that pertain to the CHQ in the multimarket firm. Indeed, given the state of the cumulative CHQ literature, it seems that we are losing sight of the fundamental challenges facing the CHQ in the multimarket firm. The four lines of inquiry and exemplary research directions that we suggested, shift the focus towards the fundamental issues 
concerning the CHQ, and to even more theory-driven research in order to clarify the role played by the CHQ as the central organizational unit in the multimarket firm.

Overall, we hope that our analysis of the literature, and particularly the schematic framework of the role played by the CHQ in the multimarket firm, will stimulate future research. While our review pinpoints selected issues, unresolved debates, and outlines promising research directions, it is a first step in outlining a holistic perspective on the CHQ. Given the importance of this entity for the functioning of the contemporary corporation, we hope that this review will serve as the foundation for scholars to build more effectively on each other's work and to improve our understanding of the CHQ in the multimarket firm. 


\section{REFERENCES}

Aarland, K., Davis, J. C., Henderson, J. V., \& Ono, Y. (2007). Spatial organization of firms: The decision to split production and administration. RAND Journal of Economics, 38(2), 480494.

Adner, R., \& Helfat, C. E. (2003). Corporate effects and dynamic managerial capabilities. Strategic Management Journal, 24, 1011-1025.

Alexander, M. (1992). Disintermediation - redefining the role of corporate headquarters. Long Range Planning, 25(6), 110-112.

Alfoldi, E. A., Clegg, L. J., \& McGaughey, S. L. (2012). Coordination at the edge of the empire: The delegation of headquarters functions through regional management mandates. Journal of International Management, 18(3), 276-292.

Ambos, T. C., Andersson, U., \& Birkinshaw, J. (2010). What are the consequences of initiativetaking in multinational subsidiaries? Journal of International Business Studies, 41(7), 10991118.

Andersson, U., \& Holm, U. (Eds.). (2010). Managing the contemporary multinational: The role of headquarters. Cheltenham, UK: Edward Elgar.

Arrfelt, M., Wiseman, R. M., McNamara, G., \& Hult, G. T. M. (2014). Examining a key corporate role: The influence of capital allocation competency on business unit performance. Strategic Management Journal, forthcoming.

Baaij, M. G., Mom, T. J. M., Van Den Bosch, F. A. J., \& Volberda, H. W. (2012a). Should top management relocate across national borders? MIT Sloan Management Review, 53(2), 1718.

Baaij, M. G., Mom, T. J. M., Van den Bosch, F. A. J., \& Volberda, H. W. (2012b). Why do multinational corporations relocate core parts of their corporate headquarters abroad? Long Range Planning, forthcoming, 1-19.

Baaij, M. G., \& Slangen, A. H. L. (2013). The role of headquarters-subsidiary geographic distance in strategic decisions by spatially disaggregated headquarters. Journal of International Business Studies, 44(9), 941-952.

Baaij, M. G., Van Den Bosch, F. A. J., \& Volberda, H. W. (2004). The international relocation of corporate centres: Are corporate centres sticky? European Management Journal, 22(2), 141149.

Balderston, F. E. (1962). Models of multiple branch organization. California Management Review, 4(3), 40-57.

Baliga, B. R., \& Jaeger, A. M. (1984). Multinational corporations: Control systems and delegation issues. Journal of International Business Studies(Fall), 25-40. 
Barney, J. B. (1991). Firm resources and sustained competitive advantage. Journal of Management, 17, 99-120.

Bartlett, C. A., \& Ghoshal, S. (1989). Managing across borders: The transnational solution. Boston, MA: Harvard Business School Press.

Barton, H., Brown, D., Cound, J., Marsh, P., \& Willey, K. (1992). Does top management add value to investment decisions? Long Range Planning, 25(5), 43-58.

Batten, F. (2002). Out of the blue and into the black. Harvard Business Review, 80(4), 112-119.

Bazzaz, S. J., \& Grinyer, P. H. (1981). Corporate planning in the U.K.: The state of the art in the 70s. Strategic Management Journal, 2(2), 155-168.

Berg, N. A. (1969). What's different about conglomerate management? Harvard Business Review, 47(6), 112-120.

Berg, N. A. (1977). The conglomerate - its strategy and structure. Paper presented at the Business History Conference.

Berger, P. G., \& Ofek, E. (1995). Diversification's effect on firm value. Journal of Financial Economics, 37, 39-65.

Berle, A. A., \& Means, G. C. (1932). The modern corporation and private property. New York, NY: Macmillan.

Birkinshaw, J., Braunerhjelm, P., Holm, U., \& Terjesen, S. (2006). Why do some multinational corporations relocate their headquarters overseas? Strategic Management Journal, 27, 681700.

Birkinshaw, J., \& Hood, N. (2001). Unleash innovation in foreign subsidiaries. Harvard Business Review, 79(3), 131-137.

Boeh, K. K., \& Beamish, P. W. (2011). Connecting flights: The time sink that kills profits. Harvard Business Review(December 2011), 30-30.

Bouquet, C., \& Birkinshaw, J. (2008). Weight versus voice: How foreign subsidiaries gain attention from corporate headquarters. Academy of Management Journal, 51(3), 577-601.

Bowman, C., \& Ambrosini, V. (2003). How the resource-based and the dynamic capability views of the firm inform corporate-level strategy. British Journal of Management, 14, 289303.

Campbell, A. (1995). Vertical integration synergy or seduction? Long Range Planning, 28(2), 126-128.

Campbell, A. (1999). Tailored, not benchmarked. A fresh look at corporate planning. Harvard Business Review, 77(2), 41. 
Campbell, A., Alexander, M., Goold, M., \& Whitehead, J. (2014). Strategy for the corporate level: Where to invest, what to cut back and how to grow organisations with multiple divisions (2nd ed.). San Francisco, CA: Jossey-Bass.

Campbell, A., Goold, M., \& Alexander, M. (1995a). Corporate strategy: The quest for parenting advantage. Harvard Business Review, 37(March/April), 120-132.

Campbell, A., Goold, M., \& Alexander, M. (1995b). The value of the parent company. California Management Review, 38(1), 79-97.

Campbell, A., Kunisch, S., \& Müller-Stewens, G. (2012). Are CEOs getting the best from corporate functions? MIT Sloan Management Review, 53(3), 12-14.

Chan, C. M., \& Makino, S. (2007). Legitimacy and multi-level institutional environments: Implications for foreign subsidiary ownership structure. Journal of International Business Studies, 38(4), 621-638.

Chandler, A. D. (1962). Strategy and structure: Chapters in the history of the American industrial enterprise. Cambridge, MA: MIT Press.

Chandler, A. D. (1991). The functions of the HQ unit in the multibusiness firm. Strategic Management Journal, 12(1), 31-50.

Chandler, A. D. (1992). Corporate strategy, structure and control methods in the United States during the 20th century. Industrial and Corporate Change, 1(2), 263-284.

Chen, D., Park, S. H., \& Newburry, W. (2009). Parent contribution and organizational control in international joint ventures. Strategic Management Journal, 30(11), 1133-1156.

Ciabuschi, F., Dellestrand, H., \& Martín, O. M. (2011). Internal embeddedness, headquarters involvement, and innovation importance in multinational enterprises. Journal of Management Studies, 48(7), 1612-1639.

Ciabuschi, F., Forsgren, M., \& Martín, O. M. (2011). Rationality vs. Ignorance: The role of MNE headquarters in subsidiaries' innovation processes. Journal of International Business Studies, 42(7), 958-970.

Coase, R. H. (1937). The nature of the firm. Economica, 4(16), 386-405.

Collis, D. (2014). International strategy: Context, concepts and implications. Hoboken, NJ: Wiley.

Collis, D. J., \& Montgomery, C. A. (1997). Corporate strategy: Resources and the scope of the firm. Boston, MA: McGraw-Hill.

Collis, D. J., \& Montgomery, C. A. (1998). Creating corporate advantage. Harvard Business Review, 76(3), 70-84. 
Collis, D. J., Young, D., \& Goold, M. (2007). The size, structure, and performance of corporate headquarters. Strategic Management Journal, 28, 383-405.

Collis, D. J., Young, D., \& Goold, M. (2012). The size and composition of corporate headquarters in multinational companies: Empirical evidence. Journal of International Management, 18(3), 260-275.

Creal, D. D., Robinson, L. A., Rogers, J. L., \& Zechman, S. L. C. (2014). The multinational advantage. Chicago Booth Research Paper No. 11-37, 57.

Crilly, D. (2011). Predicting stakeholder orientation in the multinational enterprise: A mid-range theory. Journal of International Business Studies, 42(5), 694-717.

Darragh, J., \& Campbell, A. (2001). Why corporate initiatives get stuck? Long Range Planning, 34(1), 33-52.

Datta, D. K., Deepak, K., \& Guthrie, J. P. (1994). Executive succession: Organizational antecedents of CEO characteristics. Strategic Management Journal, 15(569-579).

Davis, J. C., \& Henderson, J. V. (2008). The agglomeration of headquarters. Regional Science \& Urban Economics, 38(5), 445-460.

Desai, M. A. (2009). The decentering of the global firm. The World Economy, 32(9), 1271-1290.

Drucker, P. (1946). The concept of the corporation. New York, NY: John Day.

DuBrule, A., Bouquet, C., \& Birkinshaw, J. (2010). Global growth at irdeto (b): A dual HQ strategy). IMD Case Study(IMD-3-2090), 1-7.

Economist. (2008). Corporate restructuring - centres of attention: Companies still have too many heads at headquartes. The Economist, 15 November, 68-68.

Economist. (2014). Fighting the flab: Corporate headquarters have put on weight, and need to slim down again. The Economist, 22 March, 62-62.

Eisenhardt, K. M. (1985). Control: Organizational and economic approaches. Management Science, 31(2), 134-149.

Fama, E. F. (1970). Efficient capital markets: A review of theory and empirical work. The Journal of Finance, 25(2), 383-417.

Ferlie, E., \& Pettigrew, A. (1996). The nature and transformation of corporate headquarters: A review of recent literature and a research agenda. Journal of Management Studies, 33(4), 495-523.

Fligstein, N. (1985). The spread of the multidivisional form among large firms, 1919-1979. American Sociological Review, 50(3), 377-391. 
Foss, K., Foss, N. J., \& Nell, P. C. (2012). MNC organizational form and subsidiary motivation problems: Controlling intervention hazards in the network MNC. Journal of International Management, 18(3), 247-259.

Foss, N. J. (1997). On the rationales of corporate headquarters. Industrial and Corporate Change, 6(2), 313-338.

Garvin, D. A., \& Levesque, L. C. (2008). The multiunit enterprise. Harvard Business Review, 86(6), 106-117.

Ghemawat, P. (2001). Distance still matters. Harvard Business Review, 2001(September), 137147.

Goold, M. (1996a). Parenting strategies for multibusiness companies. Long Range Planning, 29(3), 419-421.

Goold, M. (1996b). Parenting strategies for the mature business. Long Range Planning, 29(3), 358-369.

Goold, M., \& Campbell, A. (1987). Strategies and styles: The role of the centre in managing diversified companies. Oxford, UK: Blackwell.

Goold, M., \& Campbell, A. (2002a). Do you have a well-designed organization? Harvard Business Review, 80(3), 117-124.

Goold, M., \& Campbell, A. (2002b). Parenting in complex structures. Long Range Planning, 35(3), 219-243.

Goold, M., Campbell, A., \& Alexander, M. (1994). Corporate-level strategy: Creating value in the multibusiness company. New York, NY: John Wiley \& Sons.

Goold, M., Pettifer, D., \& Young, D. (2001). Redesigning the corporate centre. European Management Journal, 19(1), 83.

Gospel, H., \& Sako, M. (2010). The unbundling of corporate functions: The evolution of shared services and outsourcing in human resource management. Industrial and Corporate Change, 19(5), 1367-1396.

Govindarajan, V. (1988). A contingency approach to strategy implemnetation at the businessunit level: Integrating administrative mechanisms with strategy. Academy of Management Journal, 31(4), 828-853.

Granovetter, M. (1973). The strength of weak ties. American Journal of Sociology, 78, 13601380.

Grant, R. M. (2003). Strategic planning in a turbulent environment: Evidence from the oil majors. Strategic Management Journal, 24, 491-517. 
Greenwood, F. (1964). Management in perspective: Effective LRP requires action. Academy of Management Journal, 7(3), 224-228.

Greenwood, R., Hinings, C. R., \& Brown, J. (1990). "P2-form" strategic management: Corporate practices in professional partnerships. Academy of Management Journal, 33(4), 725-755.

Guadalupe, M., Li, H., \& Wulf, J. (2014). Who lives in the C-suite? Organizational structure and the division of labor in top management. Management Science, 60(4), 824-844.

Gupta, A. K. (1987). SBU strategies, corporate-SBU relations, and SBU effectiveness in strategy implementation. Academy of Management Journal, 30(3), 477-500.

Gupta, A. K., \& Govindarajan, V. (1991). Knowledge flows and the structure of control within multinational corporations. Academy of Management Review, 16(4), 768-792.

Hanan, M. (1969). Corporate growth through internal spin-outs. Harvard Business Review, 47(6), 55-67.

Hansen, O. C., \& Peytz, M. (1991). Designing the corporate center. McKinsey Quarterly, 1991(3), 128-139.

Henderson, J. V., \& Ono, Y. (2008). Where do manufacturing firms locate their headquarters? Journal of Urban Economics, 63(2), 431-450.

Hill, C. W. L., Hitt, M. A., \& Hoskisson, R. E. (1992). Cooperative versus competitive structures in related and unrelated diversified firms. Organization Science, 3(4), 501-521.

Hill, C. W. L., \& Hoskisson, R. E. (1987). Strategy and structure of the multiproduct firm. Academy of Management Review, 12(2), 331-341.

Hitt, M. A., \& Ireland, R. D. (1986). Relationships among corporate level distinctive competences, diversification strategy, corporate structure and performance. Journal of Management Studies, 23(4), 401-416.

Hitt, M. A., \& Ireland, R. D. (1987). Building competitive strength in international markets. Long Range Planning, 20(1), 115-122.

Hoenen, A. K., \& Kostova, T. (2014). Utilizing the broader agency perspective for studying headquarters-subsidiary relations in multinational companies. Journal of International Business Studies, Forthcoming, 1-10.

Hoskisson, R. E. (1987). Multidivisional structure and performance: The contingency of diversification strategy. Academy of Management Journal, 30, 625-644.

Howard, R. (1991). The designer organization: Italy's gft goes global. Harvard Business Review, 69(5), 28-44. 
Hungenberg, H. (1993). How to ensure that headquarters add value. Long Range Planning, 26(6), 62-73.

Jacque, L. L., \& Vaaler, P. M. (2001). The international control conundrum with exchange risk: An eva framework. Journal of International Business Studies, 32(4), 813.

Jensen, M., \& Zajac, E. J. (2004). Corporate elites and corporate strategy: How demographic preferences and structural position shape the scope of the firm. Strategic Management Journal, 25, 507-524.

Jensen, M. C., \& Meckling, W. (1976). Theory of the firm: Managerial behavior, agency costs, and ownership structure. Journal of Financial Economics, 3, 305-360.

Joseph, J., \& Ocasio, W. (2012). Architecture, attention, and adaptation in the multibusiness firm: General electric from 1951 to 2001. Strategic Management Journal, 33(6), 633-660.

Kaplan, R. S., \& Norton, D. P. (2005). The office of strategy management. Harvard Business Review, 83(10), 72-80.

Khanna, T., \& Palepu, K. (2000). Is group affiliation profitable in emerging markets? An analysis of diversified indian business groups. The Journal of Finance, 55(2), 867-891.

Kim, W. C., \& Mauborgne, R. A. (1991). Implementing global strategies: The role of procedual justive. Strategic Management Journal, 12, 125-143.

Kleinbaum, A. M., \& Stuart, T. E. (2014). Inside the black box of the corporate staff: Social networks and the implementation of corporate strategy. Strategic Management Journal, $35(1), 24-47$.

Knight, F. H. (1921). Risk, uncertainty and profit (Vol. (reprinted 1965)). New York: Augustus M. Kelley.

Kono, T. (1999). A strong head office makes a strong company. Long Range Planning, 32(2), 225-236.

Kownatzki, M., Walter, J., Floyd, S., \& Lechner, C. (2013). Corporate control and the speed of strategic business unit decision making. Academy of Management Journal, 56(5), 12951324.

Kunisch, S., \& Bilhuber Galli, E. (2014). Three traps facing new corporate center executives. The European Business Review, 2014(Sep-Oct), 85-88.

Kunisch, S., Menz, M., \& Ambos, B. (2014). Changes at corporate headquarters: Review, integration and research agenda. International Journal of Management Reviews, Forthcoming, 1-56.

Kunisch, S., Müller-Stewens, G., \& Campbell, A. (2014). Why corporate functions stumble. Harvard Business Review, 92(10), 110-117. 
Kunisch, S., Müller-Stewens, G., \& Collis, D. J. (2012). Housekeeping at corporate headquarters: International trends in optimizing the size and scope of corporate headquarters, survey report. St. Gallen/Boston: University of St. Gallen/Harvard Business School.

Laamanen, T., Simula, T., \& Torstila, S. (2012). Cross-border relocations of headquarters in Europe. Journal of International Business Studies, 43, 187-210.

Lange, D., Boivie, S., \& Henderson, A. D. (2009). The parenting paradox: How multibusiness diversifiers endorse disruptive technologies while their corporate children struggle. Academy of Management Journal, 52(1), 179-198.

Law, K. S., Song, L. J., Wong, C.-S., \& Chen, D. (2009). The antecedents and consequences of successful localization. Journal of International Business Studies, 40(8), 1359-1373.

Lawrence, P. R., \& Lorsch, J. W. (1967). Organizations and environment. Boston, MA: Harvard University.

Leontiades, M., \& Tezel, A. (1981). Some connections between corporate-level planning and diversity. Strategic Management Journal, 2(4), 413-418.

Lorsch, J. W., \& Allen, S. A. (1973). Managing diversity and interdependence: An organizational study of multidivisional firms. Boston, MA: Graduate School of Business Administration, Harvard University.

MacMillan, I. C., \& Meshulach, A. (1983). Replacement versus expansion - dilemma for mature united-states businesses. Academy of Management Journal, 26(4), 708-726.

Mahnke, V., Ambos, B., Nell, P. C., \& Hobdari, B. (2012). How do regional headquarters influence corporate decisions in networked MNCs? Journal of International Management, 18(3), 293-301.

Markides, C. C. (2002). Corporate strategy: The role of the centre. In A. Pettigrew, H. Thomas \& R. Whittington (Eds.), Handbook of strategy and management (pp. 98-111). London: Sage.

Markides, C. C., \& Williamson, P. J. (1994). Related diversification, core competences and corporate performance. Strategic Management Journal, 15(Summer Special Issue), 149-165.

Markides, C. C., \& Williamson, P. J. (1996). Corporate diversification and organizational structure: A resource-based view. Academy of Management Journal, 39(2), 340-367.

Markovitz, H. (1952). Portfolio selection. Journal of Finance, 7, 77-91.

Marshall, A. (1890). Principles of economics. London, UK: Macmillan.

Martin, J. A., \& Eisenhardt, K. M. (2010). Rewiring: Cross-business-unit collaborations in multibusiness organizations. Academy of Management Journal, 53(2), 265-301. 
Martinez, J. I., \& Jarillo, J. C. (1989). The evolution of research on coordination mechanisms in multinational-corporations. Journal of International Business Studies, 20(3), 489-514.

Martinez, Z. L., \& Ricks, D. A. (1989). Multinational parent companies' influence over human resource decisions of affiliates: U.S. Firms in mexico. Journal of International Business Studies, 20(3), 465-487.

McGahan, A. M., \& Porter, M. E. (1997). How much does industry matter, really? Strategic Management Journal, 18(Summer Special Issue), 15-30.

McGahan, A. M., \& Porter, M. E. (2002). What do we know about variance in accounting profitability? Management Science, 48(7), 834-851.

McInnes, J. M. (1971). Financial control systems for multinational operations: An empirical investigation. Journal of International Business Studies, 2(1), 11-28.

McKinseyGlobalInstitute. (2013). Urban world: The shifting global business landscape. In McKinseyGlobalInstitute (Ed.).

Melman, S. (1951). The rise of administrative overhead in the manufacturing industries of the United States 1899-1947. Oxford Economic Papers. New Series, 3, 62-112.

Menz, M. (2012). Functional top management team members: A review, synthesis, and research agenda. Journal of Management, 38(1), 45-80.

Menz, M., \& Scheef, C. (2014). Chief strategy officers: Contingency analysis of their presence in top management teams. Strategic Management Journal, 35(3), 461-471.

Miller, C. C., Washburn, N. T., \& Glick, W. H. (2013). Perspective - the myth of performance. Organization Science, 24(3), 948-964.

Miller, K. D., \& Waller, H. G. (2003). Scenarios, real options and integrated risk management. Long Range Planning, 36(1), 93.

Mintzberg, H. (1979). The structuring of organizations: A synthesis of the research. Englewood Cliffs, NJ: Prentice-Hall.

Modigliani, F., \& Miller, M. H. (1958). The cost of capital, corporation finance and the theory of investment. American Economic Review, 48(3), 261-297.

Montague, R. (1986). Separate corporate headquarters have an economic impact on plant operations. American Business Review, 4(1), 20.

Murdick, R. G. (1964). The long-range planning matrix. California Management Review, 7(2), 35-42. 
Nell, P. C., \& Ambos, B. (2013). Parenting advantage in the MNC: An embeddedness perspective on the value added by headquarters. Strategic Management Journal, 34(9), 1086-1103.

Nohria, N., \& Ghoshal, S. (1994). Differentiated fit and shared values - alternatives for managing headquarters subsidiary relations. Strategic Management Journal, 15(6), 491-502.

Nohria, N., \& Ghoshal, S. (1997). The differentiated network: Organizing multinational corporations for value creation. San Francisco, CA: Jossey-Bass.

O'Donnell, S. W. (2000). Managing foreign subsidiaries: Agents of headquarters, or an independent network? Strategic Management Journal, 21, 525-548.

Ohmae, K. (1989). Planting for a global harvest. Harvard Business Review, 67(4), 136-145.

Ouchi, W. G., \& Maguire, M. A. (1975). Organizational control: Two functions. Administrative Science Quarterly, 20(4), 559-569.

Parks, F. N. (1974). What role for the European HQ--and where? Harvard Business Review, $52(4), 6$.

Parmigiani, A., \& Holloway, S. S. (2011). Actions speak louder than modes: Antecedents and implications of parent implementation capabilities on business unit performance. Strategic Management Journal, 32(5), 457-485.

Pasternack, B. A., \& Viscio, A. J. (1998). The centerless corporation: A new model for transforming your organization for growth and prosperity. New York, NY: Simon \& Schuster.

Penrose, E. T. (1959). The theory of the growth of the firm. Oxford: Blackwell.

Pettifer, D. (1998). Measuring the performance of the corporate centre. Long Range Planning, 31(5), 783-785.

Pfeffer, J., \& Salancik, G. (1978). The external control of organizations: A resource-dependence theory. New York, NY: Harper \& Row.

Pitts, R. A. (1976). Diversification strategies and organizational policies of large diversified firms. Journal of Economics and Business, 28, 181-188.

Pitts, R. A. (1977). Strategies and structures for diversification. Academy of Management Journal, 20, 197-208.

Plourde, Y., Parker, S. C., \& Schaan, J.-L. (2014). Expatriation and its effect on headquarters' attention in the multinational enterprise. Strategic Management Journal, 35(6), 938-947. 
Poppo, L. (2003). The visible hands of hierarchy within the m-form: An empirical test of corporate parenting of internal product exchanges. Journal of Management Studies, 40(2), 403-430.

Porter, M. E. (1987). From competitive advantage to corporate strategy. Harvard Business Review, 65(3), 43-59.

Porter, M. E. (1990). The competitive advantage of nations. New York, NY: Free Press.

Prahalad, C. K., \& Bettis, R. A. (1986). The dominant logic: A new linkage between diversity and performance. Strategic Management Journal, 7(6), 485-501.

Prahalad, C. K., \& Doz, Y. (1987). The multinational mission. New York, NY: Free Press.

Rajagopalan, N., \& Datta, D. K. (1996). CEO characteristics: Does industry matter? Academy of Management Journal, 39(1), 197-215.

Rajan, R. G., \& Wulf, J. (2006). The flattening firm: Evidence from panel data on the changing nature of corporate hierarchies. Review of Economics \& Statistics, 88(759-773).

Raynor, M. E., \& Bower, J. L. (2001). Lead from the center: How to manage divisions dynamically. Harvard Business Review, 79(5), 92-100.

Roth, K., \& Nigh, D. (1992). The effectiveness of headquarters-subsidiary relationships: The role of coordination, control, and conflict. Journal of Business Research, 25(4), 277-301.

Roth, K., \& O'Donnell, S. (1996). Foreign subsidiary compensation strategy: An agency theory perspective. Academy of Management Journal, 39(3), 678-703.

Rugman, A. M., \& Verbeke, A. (2001). Subsidiary-specific advantages in multinational enterprises. Strategic Management Journal, 22, 237-250.

Rumelt, R. P., Schendel, D. E., \& Teece, D. J. (1994). Fundamental issues in strategy. In R. P. Rumelt, D. E. Schendel \& D. J. Teece (Eds.), Fundamental issues in strategy: A research agenda. Boston, MA: Harvard Business School Press.

Russo, M. V. (1992). Bureaucracy, economic regulation, and the incentive limits of the firm. Strategic Management Journal, 13(2), 103-118.

Rutenberg, D. P. (1969). Planning for a multi -- national synergy. Long Range Planning, 2(2), 24-26.

Scharfstein, D. S. (1998). The dark side of internal capital markets ii: Evidence from diversified conglomerates. NBER Working Paper, (6352). Cambridge.

Scharfstein, D. S., \& Stein, J. C. (2000). The dark side of internal capital markets: Divisional rent-seeking and inefficient investment. Journal of Finance, 55(6), 2537-2564. doi: 10.1111/0022-1082.00299 
Schollhammer, H. (1971). Organization structures of multinational corporations. Academy of Management Journal, 14(3), 345-365.

Semadeni, M., \& Cannella Jr., A. A. (2011). Examining the performance effects of post spin-off links to parent firms: Should the apron strings be cut? Strategic Management Journal, 32(10), 1083-1098.

Sengul, M., \& Gimeno, J. (2013). Constrained delegation: Limiting subsidiaries' decision rights and resources in firms that compete across multiple industries. Administrative Science Quarterly, 58(3), 420-471.

Short, J. (2009). The art of writing a review article. Journal of Management, 35(6), 1312-1317.

Sloan, A. P. (1964). My years with general motors. Garden City, NY: Doubleday.

Song, J. (2002). Firm capabilities and technology ladders: Sequential foreign direct investments of japanese electronic firms in east asia. Strategic Management Journal, 23(3), 191-210.

Song, J. H. (1982). Diversification strategies and the experience of top executives of large firms. Strategic Management Journal, 3(4), 377-380.

Spender, J.-C. (1989). Industry recipes: The nature and sources of managerial judgment. Oxford, UK: Basic Blackwell.

Stalk Jr., G. (2005). Rotate the core. Harvard Business Review, 83(3), 18-19.

Strauss-Kahn, V., \& Vives, X. (2009). Why and where do headquarters move? Regional Science \& Urban Economics, 39(2), 168-186.

Stubbart, C. (1982). Are environmental scanning units effective? Long Range Planning, 15(3), 139-145.

Summers, C. W. (1965). Labor relations in the common market. Harvard Business Review, $43(2), 148-160$.

Surroca, J., Tribo, J. A., \& Zahra, S. A. (2013). Stakeholder pressure on mnes and the transfer of socially irresponsible practices to subsidiaries. Academy of Management Journal, 56(2), 549-572.

Takeuchi, R., Shay, J. P., \& Li, J. (2008). When does decision autonomy increase expatriate managers' adjustment? An empirical test. Academy of Management Journal, 51(1), 45-60.

Tan, B., \& Vertinsky, I. (1996). Foreign direct investment by japanese electronics firms in the united states and canada: Modelling the timing of entry. Journal of International Business Studies, 27(4), 655-681.

Tanriverdi, H., \& Venkatraman, N. (2005). Knowledge relatedness and the performance of multibusiness firms. Strategic Management Journal, 26(2), 97-119. 
Teece, D. J. (1980). Economies of scope, and the scope of the enterprise. Journal of Economic Behavior and Organization 1, 223-247.

Teece, D. J. (1982). Towards an economic theory of the multiproduct firm. Journal of Economic Behavior and Organization, 3, 39-63.

Teece, D. J. (2014). A dynamic capabilties-based entrepreneurial theory of the multinational enterprise. Journal of International Business Studies, 45, 8-37.

Thurm, D. (2005). Master of the house. Harvard Business Review, 83(10), 120-129.

Tomassen, S., Benito, G. R. G., \& Lunnan, R. (2012). Governance costs in foreign direct investments: A MNC headquarters challenge. Journal of International Management, 18(3), 233-246.

Unknown. (1929). The effect of the subsidiary corporation on the parent company. Harvard Business Review, 7(4), 496-504.

Vahlne, J.-E., Schweizer, R., \& Johanson, J. (2012). Overcoming the liability of outsidershipthe challenge of HQ of the global firm. Journal of International Management, 18(3), 224232.

Van Oijen, A., \& Douma, S. (2000). Diversification strategy and the roles of the centre. Long Range Planning, 33(4), 560-578.

Vancil, R. F., \& Lorange, P. (1975). Strategic planning in diversified companies. Harvard Business Review, 53(1), 81-90.

Walter, S. G., Heinrichs, S., \& Walter, A. (2014). Parent hostility and spin-out performance. Strategic Management Journal, 35(13), 2031-2042.

Webster, J., \& Watson, R. T. (2002). Analyzing the past to prepare for the future: Writing a literature review. MIS Quarterly, 26(2), XIII-XXIII.

Wernerfelt, B. (1984). A resource-based view of the firm. Strategic Management Journal, 5, 171-180.

Williamson, O. E. (1975). Markets and hierarchies: Analysis and antitrust implications: A study in the economics of internal organization. New York, NY: Free Press.

Williamson, O. E. (1981). The economics of organization: The transaction cost approach. American Journal of Sociology, 87, 548-577.

Williamson, O. E. (1985). The economic institutions of capitalism. New York, NY: Free Press.

Williamson, O. E. (1991). Strategizing, economizing, and economic organization. Strategic Management Journal, 12, 75-94. 
Yavitz, B., \& Newman, W. H. (1982). What the corporation should provide its business units. Journal of Business Strategy, 3(1), 14-19.

Young, D. (1993). Headquarters staff - products of history or sources of distinctive skills. Long Range Planning, 26(5), 139-141.

Young, D. (1998a). Benchmarking corporate headquarters. Long Range Planning, 31(6), 933936.

Young, D., \& Goold, M. (1993). Effective headquarters staff - a guide to the size, structure and role of corporate headquarters staff. London: Ashridge Strategic Management Centre.

Young, D. J. (1998b). Benchmarking corporate headquarters. Long Range Planning, 31(6), 933936. 
TABLE 1

Two Streams of CHQ Research

\begin{tabular}{|c|c|c|}
\hline & Multibusiness Firm & Multinational Firm \\
\hline Typical CHQ terms & $\begin{array}{l}\text { Corporate center; corporate headquarters; general office; parent } \\
\text { (company); parent firm }\end{array}$ & $\begin{array}{l}\text { Central administrative office; (corporate) headquarters; global } \\
\text { headquarters }\end{array}$ \\
\hline Intellectual roots & $\begin{array}{l}\text { Chandler (1962); Drucker (1946); Lawrence \& Lorsch (1967); } \\
\text { Lorsch \& Allen (1973); Sloan (1964) }\end{array}$ & $\begin{array}{l}\text { Baliga \& Jaeger (1984); Bartlett \& Ghoshal (1989); Prahalad \& Doz } \\
\text { (1987) }\end{array}$ \\
\hline $\begin{array}{l}\text { Perspective on the } \\
\text { CHQ }\end{array}$ & $\begin{array}{l}\text { Ability and importance of the CHQ to create value for the overall } \\
\text { firm } \\
\text { Mainly top-down perspective: "The CHQ is in control" of the } \\
\text { product divisions }\end{array}$ & $\begin{array}{l}\text { Ability and importance of the subsidiaries contributing to value } \\
\text { creation for the overall firm } \\
\text { Mainly bottom-up perspective: "Differentiated network" of } \\
\text { independent nodes of subsidiaries and the CHQ as the network } \\
\text { switch for horizontal linkages }\end{array}$ \\
\hline Topics & $\begin{array}{l}\text { CHQ roles and design; CHQ/firm boundaries; CHQ } \\
\text { resources/capabilities; CHQ-product divisions; CHQ value } \\
\text { added/destroyed }\end{array}$ & $\begin{array}{l}\text { CHQ (re)location; CHQ-international subsidiary relationships; } \\
\text { CHQ and organization structure }\end{array}$ \\
\hline \begin{tabular}{|l|} 
Theories \\
\end{tabular} & $\begin{array}{l}\text { Economic: Transaction cost economics; financial economics } \\
\text { Organizational: Agency theory; contingency theory; resource-based } \\
\text { view; dynamic capabilities }\end{array}$ & $\begin{array}{l}\text { Economic: Economic geography; international business } \\
\text { Organizational: Agency theory; resource-dependence theory; control } \\
\text { theory; institutional theory; attention-based view; stakeholder theory }\end{array}$ \\
\hline Methods & $\begin{array}{l}\text { Qualitative fieldwork; quantitative analysis (e.g., surveys and } \\
\text { archival data); conceptual (generic normative frameworks) }\end{array}$ & $\begin{array}{l}\text { Quantitative analysis (e.g., surveys of subsidiaries in multinational } \\
\text { corporations) }\end{array}$ \\
\hline Exemplary studies & $\begin{array}{l}\text { Adner \& Helfat (2003); Campbell, Goold, \& Alexander (1995a); } \\
\text { Chandler (1991); Collis \& Montgomery (1997); Collis, Young, \& } \\
\text { Goold (2007); Goold \& Campbell (1987; 2002b); Goold, Campbell, } \\
\text { \& Alexander (1994); Hungenberg (1993); Russo (1992); Semadeni } \\
\text { \& Cannella (2011) }\end{array}$ & $\begin{array}{l}\text { Birkinshaw, Braunerhjelm, Holm, \& Terjesen (2006); Bouquet \& } \\
\text { Birkinshaw (2008); Chen, Park, \& Newburry (2009); Collis, Young, } \\
\text { \& Goold (2012); Nell \& Ambos (2013) }\end{array}$ \\
\hline
\end{tabular}


TABLE 2

Fundamental Inquiries with Exemplary Directions for Future CHQ Research

\begin{tabular}{|c|c|}
\hline $\begin{array}{l}\text { Fundamental } \\
\text { Inquiry }\end{array}$ & Exemplary Directions \\
\hline $\begin{array}{l}\text { The CHQ's } \\
\text { scope }\end{array}$ & $\begin{array}{l}\text { - Examine how external forces, such as institutions, globalization, and digitalization, affect the scope of } \\
\text { the multibusiness firm's CHQ's } \\
\text { - Study the physical location of the multibusiness firm's CHQ (e.g., distance to product divisions) } \\
\text { - Explore the roles of the CHQ in the multinational firm } \\
\text { - Specify the characteristics and the (internal and external) boundaries of the multimarket firm's CHQ } \\
\text { - Explore the emergence of new CHQ types and of the CHQ's individual parts in the multimarket firm } \\
\text { (e.g., virtual CHQ, dispersed CHQ) }\end{array}$ \\
\hline $\begin{array}{l}\text { The CHQ's } \\
\text { relations }\end{array}$ & $\begin{array}{l}\text { - Develop multidimensional frameworks for studying the business portfolio's effect on the CHQ roles } \\
\text { and design } \\
\text { - Explore how the CHQ can "leverage" its capabilities (e.g., alliance, HR, M\&A) to the geographic units } \\
\text { - Study "broader," horizontal CHQ integrating mechanisms in the multibusiness firm (e.g., socialization, } \\
\text { shared purpose), consider vertical CHQ integrating mechanisms in the multinational firm (e.g., } \\
\text { formalization, control), and juxtapose the multimarket firm's CHQ integrating mechanisms and } \\
\text { parenting styles for the business and geographic units } \\
\text { - Examine the nature and evolution of CHQ-operating unit relationships in the multimarket firm, } \\
\text { accounting specifically for heterogeneous portfolios' complexity and for the coordination and } \\
\text { collaboration processes within the firm } \\
\text { - Explore the externally-facing role of the multimarket firm's CHQ, as well as the nature, design, and } \\
\text { effectiveness of the CHQ-external stakeholder relations }\end{array}$ \\
\hline & $\begin{array}{l}\text { - Examine the characteristics and behavior of cross-functional teams and sub-units in the multibusiness } \\
\text { firm's CHQ } \\
\text { - Study resource allocation processes in the multinational firm's CHQ (e.g., the usage of tools, such as a } \\
\text { growth share matrix) } \\
\text { - Analyze the decision and collaboration processes within the multimarket firm's CHQ (e.g., actors, } \\
\text { design) } \\
\text { - Investigate the factors that affect the decision to have a specific corporate function (e.g., HR, IT, } \\
\text { strategy) in the multimarket firm's CHQ and its characteristics } \\
\text { - Explore the staffing of the multimarket firm's CHQ (e.g., selection criteria, traits, career paths) }\end{array}$ \\
\hline $\begin{array}{l}\text { The CHQ's } \\
\text { raison d'être }\end{array}$ & $\begin{array}{l}\text { - Study the extent to which and how the multibusiness firm's CHQ affects the business unit's } \\
\text { intermediate outcomes, such as strategic change and innovation, as well as the financial performance } \\
\text { - Examine how the multinational firm's CHQ affects firm-level performance outcomes (e.g., profitability, } \\
\text { growth, market-based performance) } \\
\text { - Advance better measures for the study of the impact of the multimarket firm's CHQ, for example, on } \\
\text { loss preventing (subtracted value) and entrepreneurial roles (value added) } \\
\text { - Study the performance effect of the multimarket firm's CHQ by considering relationship-based } \\
\text { outcomes (e.g., tensions, CHQ attention) and alternative outcomes (e.g., symbolic value) } \\
\text { - Uncover how multiple contingencies and their interactions affect the effect of the multimarket firm's } \\
\text { CHQ on intermediate and performance outcomes }\end{array}$ \\
\hline
\end{tabular}


FIGURE 1

Development of the Cumulative Number of CHQ Publications from 1962 to 2014

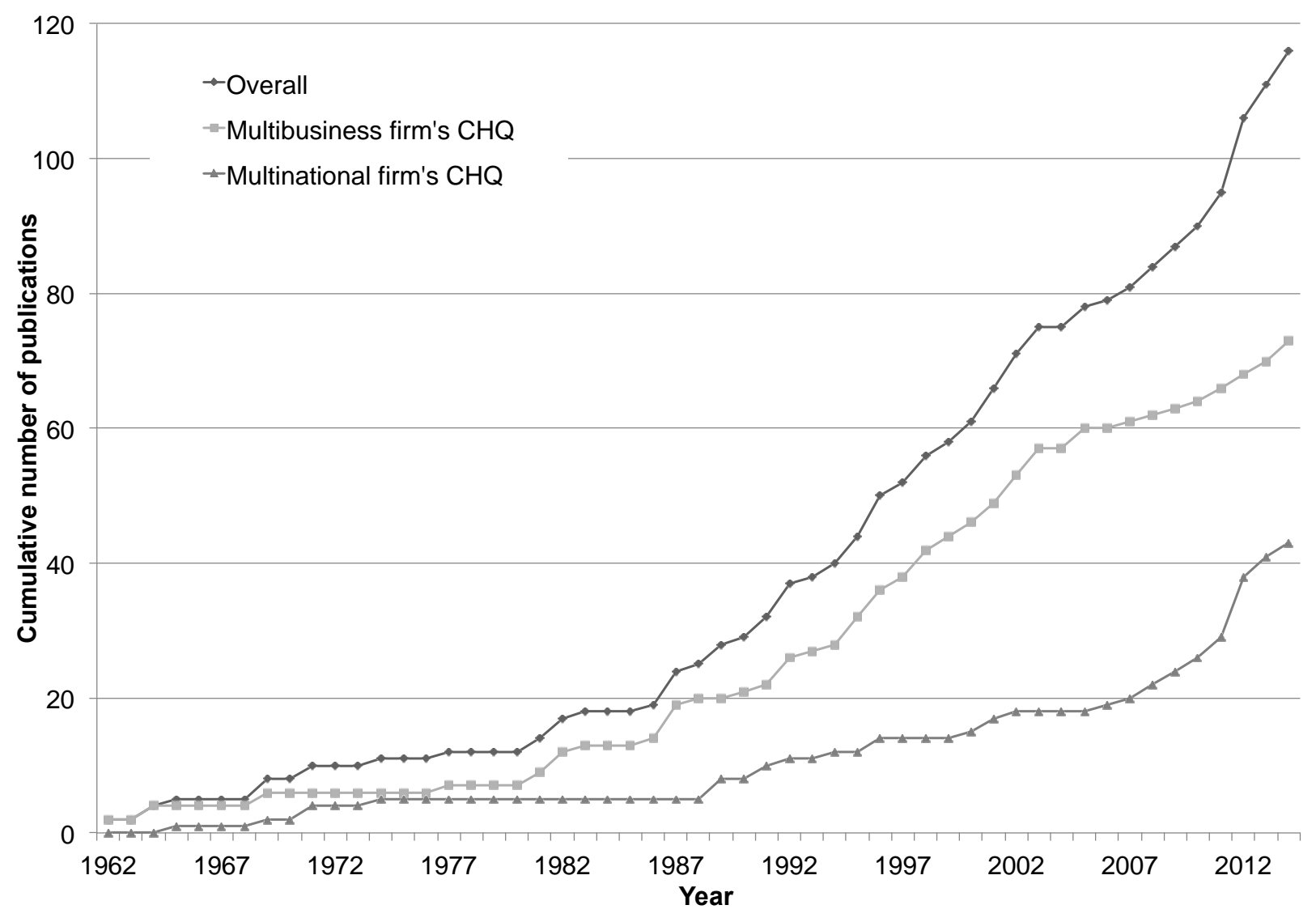


FIGURE 2

Organizing Framework of Research on the CHQ

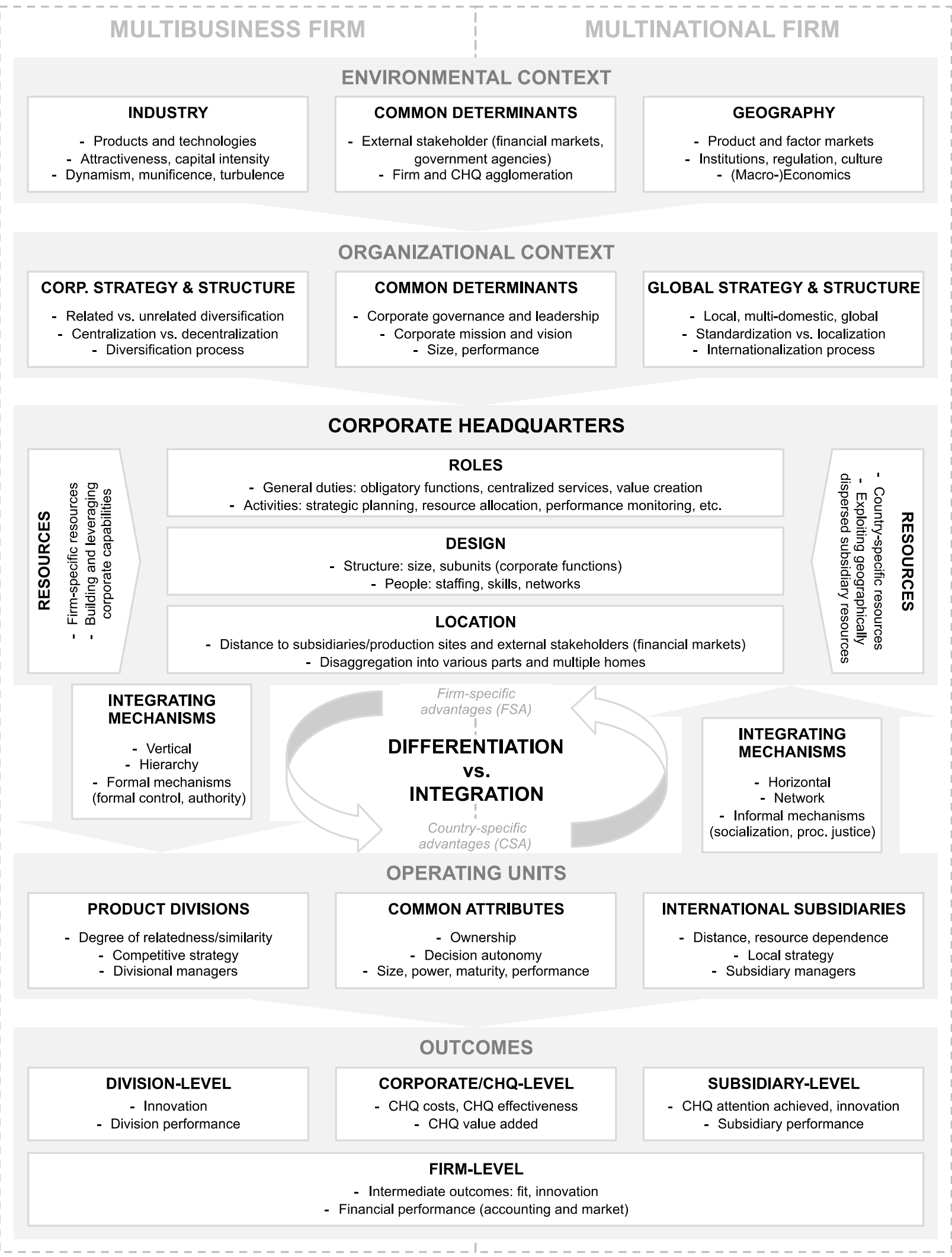




\section{APPENDIX 1 \\ Selected CHQ Terms and Definitions (in Chronological Order)}

\begin{tabular}{|c|c|c|}
\hline Term & Definition & Source \\
\hline General office & $\begin{array}{l}\text { "At the top is a general office. There, general executives and staff specialists } \\
\text { coordinate, appraise, and plan goals and policies and allocate resources for a } \\
\text { number of quasi-autonomous, fairly self-contained divisions" (p. 9) }\end{array}$ & Chandler (1962) \\
\hline Strategic apex & $\begin{array}{l}\text { "The strategic apex is charged with ensuring that the organization serve its } \\
\text { mission in an effective way, and also that it serve the needs of those people } \\
\text { who control or otherwise have power over the organization" (p. 25) } \\
\text { Comment: } \\
\text { - The link between the strategic apex and the CHQ is explicated for the } \\
\text { divisionalized form as: "the structural relationship between the } \\
\text { headquarters and the divisions, in effect between the strategic apex and } \\
\text { the top of the middle line" (p. } 381 \text { ); } \\
\text { Depending on the scope of the definition, two other parts } \\
\text { (technostructure and support staff) can, to some extent, also be } \\
\text { considered the CHQ. }\end{array}$ & Mintzberg (1979) \\
\hline Corporation & $\begin{array}{l}\text { "[...] refers to the parent organization which owns several business units." } \\
\text { (p. 14) }\end{array}$ & $\begin{array}{l}\text { Yavitz \& Newman } \\
(1982)\end{array}$ \\
\hline $\begin{array}{l}\text { Central } \\
\text { administrative } \\
\text { office }\end{array}$ & $\begin{array}{l}{[\ldots] \text { the functions of employees include general company policy }} \\
\text { determination, planning, and management (i.e., company purchasing, } \\
\text { accounting, general engineering, direction of company personnel matters, } \\
\text { and legal and patent matters)." (p. 20) }\end{array}$ & Montague (1986) \\
\hline $\begin{array}{l}\text { Corporate } \\
\text { center }\end{array}$ & $\begin{array}{l}\text { "[...] the apparatus of CEO and other top managers, plus the staff advising } \\
\text { them" (p. 128) }\end{array}$ & $\begin{array}{l}\text { Hansen \& Peytz } \\
(1991)\end{array}$ \\
\hline $\begin{array}{l}\text { Corporate } \\
\text { headquarters }\end{array}$ & $\begin{array}{l}\text { "[...] include corporate directors, central functions such as finance and } \\
\text { personnel, and other staff functions that coordinate across business } \\
\text { operations" (p. 4) } \\
\text { "Focused on: } \\
\text { - provide advice, information, guidance or other services to the parent } \\
\text { company or to the business units, } \\
\text { - do not primarily trade with outside customers or clients, } \\
\text { - report directly to the CHQ, rather than to business units or intermediate } \\
\text { management levels" (p. 4) }\end{array}$ & $\begin{array}{l}\text { Young \& Goold } \\
(1993)\end{array}$ \\
\hline $\begin{array}{l}\text { Corporate } \\
\text { parent (parent } \\
\text { organization) }\end{array}$ & $\begin{array}{l}\text { Comment: no explicit definition but identifies five categories of a parent } \\
\text { organization: (1) mental maps; (2) corporate structures, systems, and } \\
\text { processes; (3) central functions, services, and resources; (4) nature, } \\
\text { experience and skills (people); and (5) decentralization contract. (p. 124) }\end{array}$ & $\begin{array}{l}\text { Campbell et al. } \\
\text { (1995a) }\end{array}$ \\
\hline $\begin{array}{l}\text { Corporate } \\
\text { parent }\end{array}$ & $\begin{array}{l}\text { "The corporate parent consists of all managers and staff not assigned to a } \\
\text { business unit, including not only the corporate headquarters but also division, } \\
\text { group, region and other intermediate levels of management." (p. 80) }\end{array}$ & $\begin{array}{l}\text { Campbell et al. } \\
\text { (1995b) }\end{array}$ \\
\hline $\begin{array}{l}\text { Corporate } \\
\text { headquarters }\end{array}$ & $\begin{array}{l}\text { "[...] a corporate hierarchy of line managers and staff outside these } \\
\text { businesses, called the 'corporate headquarters' (CHQ). Generally, the CHQ } \\
\text { includes functions that coordinate activities across business units. I here } \\
\text { follow Chandler (1994) (but not Young and Goold, 1993) in thinking of the } \\
\text { CHQ as also including top-level management." (p. 313) }\end{array}$ & Foss (1997) \\
\hline $\begin{array}{l}\text { Corporate } \\
\text { centre }\end{array}$ & $\begin{array}{l}\text { "[...] the physical corporate centre as a part of the home base or corporate } \\
\text { parent." (p. 142) }\end{array}$ & $\begin{array}{l}\text { Baaij, Van Den } \\
\text { Bosch, \& } \\
\text { Volberda (2004) }\end{array}$ \\
\hline
\end{tabular}




\begin{tabular}{|c|c|c|}
\hline Term & Definition & Source \\
\hline $\begin{array}{l}\text { Headquarters } \\
\text { and corporate } \\
\text { headquarters }\end{array}$ & $\begin{array}{l}\text { "[...] the HQ as having two essential elements: a top management group that } \\
\text { typically has an official location at which it meets, and a series of HQ } \\
\text { functions that have the formal responsibility for fulfilling the roles discussed } \\
\text { above (treasury, investor relations, corporate communications etc.), each one } \\
\text { of which has an identifiable physical location. There is also a third element in } \\
\text { the case of the corporate HQ (but not the business unit HQ), namely the legal } \\
\text { domicile- the registration of the MNC in a particular sovereign nation, } \\
\text { under which all the other legal entities that make up the MNC can be } \\
\text { grouped." (p. } 684 \text { ) }\end{array}$ & $\begin{array}{l}\text { Birkinshaw et al. } \\
\text { (2006) }\end{array}$ \\
\hline $\begin{array}{l}\text { Central } \\
\text { administrative } \\
\text { office }\end{array}$ & $\begin{array}{l}\text { "administrative units including headquarters, which process information both } \\
\text { within and between firms." (p. 480) }\end{array}$ & $\begin{array}{l}\text { Aarland, Davis, } \\
\text { Henderson, \& Ono } \\
\text { (2007) }\end{array}$ \\
\hline $\begin{array}{l}\text { Corporate } \\
\text { headquarters }\end{array}$ & $\begin{array}{l}\text { "[...] staff functions and executive management with responsibility for, or } \\
\text { providing services to, the whole of (or most of) the company, excluding staff } \\
\text { employed in divisional headquarters." (p. 385) }\end{array}$ & Collis et al. (2007) \\
\hline $\begin{array}{l}\text { Central } \\
\text { administrative } \\
\text { office }\end{array}$ & $\begin{array}{l}\text { "These facilities [...] produce services that are consumed by the operating } \\
\text { units and plants of their firms. Examples include strategic planning, business, } \\
\text { financial and resource planning, as well as centralized ancillary, } \\
\text { administrative services such as legal, accounting, and the like. Some of these } \\
\text { services may be out-sourced, given out-sourcing is also a central function of } \\
\text { HQ's." (p. 446) }\end{array}$ & \begin{tabular}{|l|} 
Davis \& \\
Henderson (2008)
\end{tabular} \\
\hline $\begin{array}{l}\text { Corporate } \\
\text { headquarters }\end{array}$ & $\begin{array}{l}\text { "[...] various departments at headquarters frame policies, develop programs, } \\
\text { and make key strategic, budgeting, pricing, and marketing decisions that } \\
\text { shape the field organization's priorities, behavior, and actions." (p. 108) }\end{array}$ & $\begin{array}{l}\text { Garvin \& } \\
\text { Levesque (2008) }\end{array}$ \\
\hline Headquarters & $\begin{array}{l}\text { "[...] process information within the firm and between firms, provide service } \\
\text { functions for the firm such as advertising, accounting and legal services, and } \\
\text { co-ordinate and administer a variety of plant level activities within the firm. } \\
\text { Sometimes firms, especially bigger firms, spatially separate administrative } \\
\text { functions from production activity and create stand-alone HQs." (p. 431) }\end{array}$ & $\begin{array}{l}\text { Henderson \& Ono } \\
(2008)\end{array}$ \\
\hline Headquarters & $\begin{array}{l}\text { "Headquarters are defined as a management center and are strictly different } \\
\text { from a plant. More specifically, in our database a headquarters corresponds } \\
\text { to a center of a firm's operations, administration and marketing activity. This } \\
\text { general definition of headquarters encompasses regional managerial centers } \\
\text { and may include sales offices. }{ }^{12} \text { A firm may have several headquarters [...]. } \\
{ }_{12} \text { This broad definition of headquarters is adequate for our work as regional } \\
\text { headquarters as well as sales offices have similar inputs requirements than } \\
\text { central headquarters in term of labor, business services or information. } \\
\text { Their relocation across cities has similar implications on employment or } \\
\text { economic activity than the relocation of central headquarters." (p. 170) }\end{array}$ & $\begin{array}{l}\text { Strauss-Kahn \& } \\
\text { Vives (2009) }\end{array}$ \\
\hline $\begin{array}{l}\text { Corporate } \\
\text { headquarters }\end{array}$ & $\begin{array}{l}\text { "[...] a home for managerial talent, a financial home and a legal home" (p. } \\
1276)\end{array}$ & Desai (2009) \\
\hline
\end{tabular}


APPENDIX 2

Summary of CHQ Research (in Chronological Order)*

\begin{tabular}{|c|c|c|c|c|c|}
\hline $\begin{array}{l}\text { Author(s) } \\
\text { (Year) }\end{array}$ & $\begin{array}{l}\text { Research } \\
\text { Stream }\end{array}$ & Focus & $\begin{array}{l}\text { Theoretical } \\
\text { Lens }\end{array}$ & Methodology & Key Findings related to the CHQ \\
\hline Chandler (1962) & $\mathrm{MBF}$ & Roles/ activities & $\begin{array}{l}\text { Organizational } \\
\text { contingency } \\
\text { theory }\end{array}$ & $\begin{array}{l}\text { In-depth field } \\
\text { study of four } \\
\text { cases in the US }\end{array}$ & $\begin{array}{l}\text { The creation of the CHQ is contingent upon the adoption of the M- } \\
\text { form structure; the CHQ has three duties: (1) coordination and } \\
\text { integration of the businesses' output, (2) centralized and specialized } \\
\text { services, and (3) performance appraisals and future resource allocation. }\end{array}$ \\
\hline $\begin{array}{l}\text { Balderston } \\
(1962)\end{array}$ & $\begin{array}{l}\text { MBF } \\
\text { (product/ } \\
\text { regional } \\
\text { branches) }\end{array}$ & $\begin{array}{l}\text { Roles/ activities; } \\
\text { env. context; } \\
\text { operating units }\end{array}$ & $\begin{array}{l}\text { Organization } \\
\text { theory (decision- } \\
\text { making schema) }\end{array}$ & $\begin{array}{l}\text { Mathematical } \\
\text { modeling/ } \\
\text { conceptual }\end{array}$ & $\begin{array}{l}\text { The CHQ duties are: (1) self-maintenance activities of the CHQ, and } \\
\text { (2) resource allocation to branches. The level of branch standardization } \\
\text { depends on the local markets' level of heterogeneity, and the CHQ } \\
\text { control mechanisms depend on the similarity of the branches. }\end{array}$ \\
\hline $\begin{array}{l}\text { Greenwood } \\
\text { (1964) }\end{array}$ & $\mathrm{MBF}$ & $\begin{array}{l}\text { Roles/ activities; } \\
\text { design; operating } \\
\text { units }\end{array}$ & $\begin{array}{l}\text { Organization } \\
\text { theory (no } \\
\text { explicit } \\
\text { theoretical lens) } \\
\end{array}$ & $\begin{array}{l}\text { Analysis of } 45 \\
\text { US firms in } 16 \\
\text { industries }\end{array}$ & $\begin{array}{l}\text { The CHQ with specialized staff helps implement strategies in three } \\
\text { ways: (1) spots changes in the external env. that are important for the } \\
\text { firm's future; (2) ensures that internal operations are in line with the } \\
\text { long-term plans; (3) provides operating managers with other support. }\end{array}$ \\
\hline Murdick (1964) & $\mathrm{MBF}$ & Roles/ activities & $\begin{array}{l}\text { Managerial (no } \\
\text { explicit } \\
\text { theoretical lens) }\end{array}$ & $\begin{array}{l}\text { Conceptual/ } \\
\text { illustrative } \\
\text { examples }\end{array}$ & $\begin{array}{l}\text { The CHQ is responsible for corporate planning concerned with the } \\
\text { firm's long-term viability and is important for developing a complete } \\
\text { and consistent set of policies and principles. }\end{array}$ \\
\hline Summers (1965) & MNF & $\begin{array}{l}\text { Env. context; } \\
\text { operating units }\end{array}$ & $\begin{array}{l}\text { Managerial (no } \\
\text { explicit } \\
\text { theoretical lens) }\end{array}$ & $\begin{array}{l}\text { Conceptual/ } \\
\text { illustrative } \\
\text { examples }\end{array}$ & $\begin{array}{l}\text { It is difficult for a central CHQ to pre-plan or transfer US labor } \\
\text { policies to European markets, due to labor relation differences between } \\
\text { Common Market countries (e.g., France, Germany, Italy) and the US. }\end{array}$ \\
\hline $\begin{array}{l}\text { Berg (1969, } \\
1977)\end{array}$ & $\mathrm{MBF}$ & $\begin{array}{l}\text { Roles/ activities; } \\
\text { org. context } \\
\text { (CSS) }\end{array}$ & $\begin{array}{l}\text { Organizational } \\
\text { contingency } \\
\text { theory }\end{array}$ & $\begin{array}{l}\text { Field study of } 10 \\
\text { Fortune } 500 \\
\text { firms }\end{array}$ & $\begin{array}{l}\text { Conglomerates and less diversified industrial firms have different } \\
\text { approaches to the CHQ's structure and role. The differences in the } \\
\text { CHQ's role are associated with differing growth patterns or } \\
\text { diversification strategies. }\end{array}$ \\
\hline Hanan (1969) & $\mathrm{MBF}$ & $\begin{array}{l}\text { Resources; org. } \\
\text { context (CSS); } \\
\text { operating units }\end{array}$ & $\begin{array}{l}\text { Managerial (no } \\
\text { explicit } \\
\text { theoretical lens) }\end{array}$ & $\begin{array}{l}\text { Conceptual/ } \\
\text { illustrative } \\
\text { examples }\end{array}$ & $\begin{array}{l}\text { Firms may spin out CHQ service functions, such as purchasing, } \\
\text { personnel, and sales management, to subsidiary profit centers, which } \\
\text { can sell services internally and externally and make a profit from } \\
\text { underutilized corporate resources. }\end{array}$ \\
\hline $\begin{array}{l}\text { Rutenberg } \\
\text { (1969) }\end{array}$ & MNF & $\begin{array}{l}\text { Roles/ activities; } \\
\text { operating units }\end{array}$ & $\begin{array}{l}\text { Managerial (no } \\
\text { explicit } \\
\text { theoretical lens) }\end{array}$ & Conceptual & $\begin{array}{l}\text { The roles of the CHQ in the MNF depend on the characteristics of the } \\
\text { international subsidiaries. Active CHQs must realize synergistic } \\
\text { benefits from multi-national coordination that exceed the behavioral } \\
\text { costs of intervening in subsidiaries' affairs. }\end{array}$ \\
\hline
\end{tabular}




\begin{tabular}{|c|c|c|c|c|c|}
\hline $\begin{array}{l}\text { Author(s) } \\
\text { (Year) }\end{array}$ & $\begin{array}{l}\text { Research } \\
\text { Stream }\end{array}$ & Focus & $\begin{array}{l}\text { Theoretical } \\
\text { Lens }\end{array}$ & Methodology & Key Findings related to the CHQ \\
\hline McInnes (1971) & MNF & $\begin{array}{l}\text { Org. context } \\
\text { (GSS); } \\
\text { integrating } \\
\text { mechanisms }\end{array}$ & $\begin{array}{l}\text { Managerial/ } \\
\text { normative }\end{array}$ & $\begin{array}{l}\text { Survey of } 30 \mathrm{US} \\
\text { multinational } \\
\text { manufacturing } \\
\text { firms }\end{array}$ & $\begin{array}{l}\text { Changes in a firm's operations from a predominately domestic base to } \\
\text { a multinational base lead to changes in its formal reporting and control } \\
\text { systems (comparison with other operating units, with historical results, } \\
\text { or with a budget), which should be considered a major undertaking. }\end{array}$ \\
\hline $\begin{array}{l}\text { Schollhammer } \\
\text { (1971) }\end{array}$ & MNF & $\begin{array}{l}\text { Org. context } \\
\text { (GSS); operating } \\
\text { units; integrating } \\
\text { mechanisms }\end{array}$ & $\begin{array}{l}\text { Organizational } \\
\text { contingency (no } \\
\text { explicit } \\
\text { theoretical lens) }\end{array}$ & $\begin{array}{l}\text { Survey of } 12 \\
\text { large US and } \\
\text { European MNF }\end{array}$ & $\begin{array}{l}\text { Despite certain similarities, US and European MNF differ in terms of: } \\
\text { (1) basic organizational orientation, (2) structure of the CHQ-foreign } \\
\text { operating units relationships, (3) the degree of centr./decentral., (4) the } \\
\text { standardization of procedures, and (5) organizational flexibility. }\end{array}$ \\
\hline Parks (1974) & MNF & $\begin{array}{l}\text { Org. context; } \\
\text { operating units }\end{array}$ & $\begin{array}{l}\text { Managerial (no } \\
\text { explicit } \\
\text { theoretical lens) }\end{array}$ & $\begin{array}{l}\text { Conceptual// } \\
\text { illustrative } \\
\text { examples; US- } \\
\text { based firms }\end{array}$ & $\begin{array}{l}\text { The structure of European HQ depends on the CHQ and the nature of } \\
\text { its European business; the choice of a location for a European HQ; the } \\
\text { corporate CEO plays a key role in making this decision. }\end{array}$ \\
\hline $\begin{array}{l}\text { Bazzaz \& } \\
\text { Grinyer (1981) }\end{array}$ & $\begin{array}{l}\text { MBF } \\
\text { (partly } \\
\text { also MNF) }\end{array}$ & $\begin{array}{l}\text { Roles/ activities; } \\
\text { org. context }\end{array}$ & $\begin{array}{l}\text { Planning (no } \\
\text { explicit } \\
\text { theoretical lens) }\end{array}$ & $\begin{array}{l}\text { Quant. and qual. } \\
\text { analysis of } 48 \\
\text { corp. planners' } \\
\text { interviews in UK }\end{array}$ & $\begin{array}{l}\text { The CHQ planning sub-units have increased in their size and scope } \\
\text { since the late 1960s. The extent of corporate planning varies between } \\
\text { the types of companies, while the staff correlates with company size. }\end{array}$ \\
\hline $\begin{array}{l}\text { Leontiades \& } \\
\text { Tezel (1981) }\end{array}$ & $\mathrm{MBF}$ & $\begin{array}{l}\text { Roles/ activities; } \\
\text { org. context } \\
\text { (CSS) }\end{array}$ & $\begin{array}{l}\text { Organizational } \\
\text { contingency } \\
\text { theory }\end{array}$ & $\begin{array}{l}\text { Survey of } 88 \\
\text { large US } \\
\text { industrial firms }\end{array}$ & $\begin{array}{l}\text { The study focuses on the planning role of the CHQ (corporate and } \\
\text { business planning): corporate planning efforts increase with an } \\
\text { increasing degree of business portfolio diversification, but the intensity } \\
\text { of corporate planning does not depend on the firm size. }\end{array}$ \\
\hline Stubbart (1982) & $\mathrm{MBF}$ & $\begin{array}{l}\text { Env. context; } \\
\text { org. context; } \\
\text { design }\end{array}$ & $\begin{array}{l}\text { Managerial/ } \\
\text { normative }\end{array}$ & $\begin{array}{l}\text { Interviews with } \\
12 \text { organizations } \\
\text { in } 1978\end{array}$ & $\begin{array}{l}\text { Firms rarely change corporate planning at the CHQ: The attitudes of } \\
\text { academics and business media, firm success, and the right staff foster } \\
\text { stability; TMT changes, decentral. moves, resource cuts, availability of } \\
\text { competent staff and alternatives (e.g. ext. forecasts) foster change. }\end{array}$ \\
\hline Teece (1982) & $\mathrm{MBF}$ & $\begin{array}{l}\text { Roles/ activities; } \\
\text { resources; org. } \\
\text { context }\end{array}$ & $\begin{array}{l}\text { Transaction cost } \\
\text { economics }\end{array}$ & Conceptual & $\begin{array}{l}\text { There are two types of diversification, lateral (i.e. related) vs. } \\
\text { conglomerate (i.e. unrelated): the former demands the exploitation of } \\
\text { "commonalities" such as physical capital and technical skills (by the } \\
\text { CHQ), whereas the latter benefits from internal capital markets. }\end{array}$ \\
\hline $\begin{array}{l}\text { Yavitz \& } \\
\text { Newman (1982) }\end{array}$ & $\mathrm{MBF}$ & $\begin{array}{l}\text { Roles/ activities; } \\
\text { env. context }\end{array}$ & $\begin{array}{l}\text { Managerial (no } \\
\text { explicit } \\
\text { theoretical lens) }\end{array}$ & Conceptual & $\begin{array}{l}\text { While the CHQ roles depend on a firm's industry the CHQ may help } \\
\text { its businesses in two ways: (1) provision of valuable resources (e.g., } \\
\text { low-cost capital, competent executives) and (2) central management of } \\
\text { synergies across businesses (corporate R\&D and marketing). }\end{array}$ \\
\hline $\begin{array}{l}\text { MacMillan \& } \\
\text { Meshulach } \\
(1983)\end{array}$ & $\mathrm{MBF}$ & $\begin{array}{l}\text { Roles/ activities; } \\
\text { org. context }\end{array}$ & $\begin{array}{l}\text { Normative/ } \\
\text { economic } \\
\text { investment } \\
\text { theory }\end{array}$ & $\begin{array}{l}\text { Quant. analysis; } \\
248 \text { firms } 1970- \\
76 \text { and } 197 \text { firms } \\
1977-1980\end{array}$ & $\begin{array}{l}\text { As indicated by an analysis of patterns of investment in expansion } \\
\text { and/or replacement of equipment by SBUs of US firms, investment } \\
\text { decisions are made at two levels: the business level and the corporate } \\
\text { level (investment decisions are ratified at the corporate level). }\end{array}$ \\
\hline
\end{tabular}




\begin{tabular}{|c|c|c|c|c|c|}
\hline $\begin{array}{l}\text { Author(s) } \\
\text { (Year) }\end{array}$ & \begin{tabular}{|l|} 
Research \\
Stream \\
\end{tabular} & Focus & $\begin{array}{l}\text { Theoretical } \\
\text { Lens }\end{array}$ & Methodology & Key Findings related to the CHQ \\
\hline $\begin{array}{l}\text { Hitt \& Ireland } \\
(1986)\end{array}$ & $\mathrm{MBF}$ & $\begin{array}{l}\text { Outcomes; org. } \\
\text { context (CSS) }\end{array}$ & $\begin{array}{l}\text { Organizational } \\
\text { contingency } \\
\text { theory }\end{array}$ & $\begin{array}{l}\text { Quant. analysis; } \\
\text { survey of } 185 \\
\text { large US } \\
\text { industrial firms }\end{array}$ & $\begin{array}{l}\text { Based on } 55 \text { distinctive competence activities categorized into eight } \\
\text { major CHQ functions, the relationship between CHQ competencies } \\
\text { and performance varies regarding different diversification strategies, } \\
\text { but not regarding different corporate structures. }\end{array}$ \\
\hline $\begin{array}{l}\text { Goold \& } \\
\text { Campbell (1987) }\end{array}$ & MBF & $\begin{array}{l}\text { Roles/ activities; } \\
\text { operating units; } \\
\text { org. context } \\
\text { (CSS); outcomes }\end{array}$ & $\begin{array}{l}\text { Control theory } \\
\text { (implicit) }\end{array}$ & $\begin{array}{l}\text { Qual. analysis; } \\
\text { field study of } 16 \\
\text { large successful } \\
\text { UK firms }\end{array}$ & $\begin{array}{l}\text { Eight different CHQ styles exist, the three most frequent ones are: } \\
\text { strategic planning, strategic control, and financial control (the styles } \\
\text { are distinguished by the extent of the planning influence and by the } \\
\text { nature of the controls); their success depends on the firm specifics. }\end{array}$ \\
\hline Gupta (1987) & MBF & $\begin{array}{l}\text { CHQ-sub } \\
\text { relations; } \\
\text { operating units; } \\
\text { outcomes }\end{array}$ & $\begin{array}{l}\text { Information- } \\
\text { processing theory }\end{array}$ & $\begin{array}{l}\text { Survey of } 58 \text { BU } \\
\text { general managers } \\
\text { in } 8 \text { Fortune } 500 \\
\text { firms }\end{array}$ & $\begin{array}{l}\text { Three dimensions characterize the CHQ-BU relations - (1) openness in } \\
\text { the CHQ-BU relations, (2) subjectivity in performance assessment, and } \\
\text { (3) decentralization - each of which influence BU effectiveness, } \\
\text { depending on the BU's strategic mission and the competitive strategy. }\end{array}$ \\
\hline $\begin{array}{l}\text { Hitt \& Ireland } \\
\text { (1987) }\end{array}$ & MBF & $\begin{array}{l}\text { Resources } \\
\text { (competencies); } \\
\text { outcomes }\end{array}$ & $\begin{array}{l}\text { No explicit } \\
\text { theoretical lens }\end{array}$ & $\begin{array}{l}\text { Conceptual/ } \\
\text { illustrative } \\
\text { examples (large } \\
\text { US firms) }\end{array}$ & $\begin{array}{l}\text { Besides other ways (product markets, technologies, and managerial } \\
\text { dominant logic), the development and application of CHQ's distinctive } \\
\text { competencies, which can be applied across all of the organization's } \\
\text { businesses, is key for the entire firm's competitive advantages. }\end{array}$ \\
\hline $\begin{array}{l}\text { Hoskisson } \\
(1987)\end{array}$ & MBF & $\begin{array}{l}\text { Org. context } \\
\text { (CSS); outcomes }\end{array}$ & $\begin{array}{l}\text { Organizational } \\
\text { contingency } \\
\text { theory }\end{array}$ & $\begin{array}{l}\text { Longitudinal } \\
\text { study of } 62 \mathrm{US} \\
\text { industrial firms } \\
\text { (archival data) }\end{array}$ & $\begin{array}{l}\text { M-form implementation increases unrel. diversifiers' performance, } \\
\text { decreases vertical integrators' perf., results of rel. diversifiers are not } \\
\text { significant. CHQ managers in highly diversified firms may focus on } \\
\text { efficiency, which may result in difficulties with responding to market } \\
\text { opportunities. }\end{array}$ \\
\hline Porter (1987) & MBF & $\begin{array}{l}\text { Org. context } \\
\text { (CSS); roles/ } \\
\text { functions; design }\end{array}$ & $\begin{array}{l}\text { Industrial } \\
\text { organization/ } \\
\text { market-based } \\
\text { view }\end{array}$ & $\begin{array}{l}\text { Archival data; } 33 \\
\text { large diversified } \\
\text { US firms; } \\
\text { illustrative cases }\end{array}$ & $\begin{array}{l}\text { There are four different concepts of corporate strategy - (1) portfolio } \\
\text { management, (2) restructuring, (3) transferring skills, and (4) sharing } \\
\text { activities - with varying implications for the CHQ's roles and design. }\end{array}$ \\
\hline $\begin{array}{l}\text { Govindarajan } \\
\text { (1988) }\end{array}$ & MBF & $\begin{array}{l}\text { Integrating } \\
\text { mechanisms; } \\
\text { operating units }\end{array}$ & $\begin{array}{l}\text { Contingency } \\
\text { theory }\end{array}$ & $\begin{array}{l}\text { Two surveys of } \\
24 \text { parent } \\
\text { companies and } \\
\text { their SBUs }\end{array}$ & $\begin{array}{l}\text { The CHQ should use different administrative mechanisms (budget } \\
\text { evaluative style, decentralization, locus of control) to manage different } \\
\text { business units. }\end{array}$ \\
\hline $\begin{array}{l}\text { Martinez \& } \\
\text { Ricks (1989) }\end{array}$ & MNF & $\begin{array}{l}\text { Resources; } \\
\text { integrating } \\
\text { mechanisms; } \\
\text { operating units }\end{array}$ & $\begin{array}{l}\text { Resource- } \\
\text { dependence } \\
\text { theory; control } \\
\text { theory }\end{array}$ & $\begin{array}{l}\text { Survey of } 115 \\
\text { Mexican } \\
\text { affiliates of US } \\
\text { MNF, } 1987\end{array}$ & $\begin{array}{l}\text { The CHQ's influence over affiliate human resource decisions is related } \\
\text { to resource dependence. The affiliate importance, the nationality of } \\
\text { affiliate managers, and the type of ownership arrangement also affect } \\
\text { parent influence, but to a lesser extent than resource dependencies. }\end{array}$ \\
\hline $\begin{array}{l}\text { Martinez \& } \\
\text { Jarillo (1989) }\end{array}$ & MNF & $\begin{array}{l}\text { CHQ-sub } \\
\text { relations; } \\
\text { integrating } \\
\text { mechanism }\end{array}$ & $\begin{array}{l}\text { Multiple, e.g. } \\
\text { coordination } \\
\text { theory, control } \\
\text { theory }\end{array}$ & $\begin{array}{l}\text { Literature } \\
\text { review; } \\
\text { conceptual }\end{array}$ & $\begin{array}{l}\text { Abandoning their unidimensional focus on structural issues, scholars } \\
\text { have turned their attention to the subtler and informal mechanisms of } \\
\text { coordination used by MNFs. MNFs might indeed make more use of } \\
\text { them, due to changes in the international competitive environment. }\end{array}$ \\
\hline
\end{tabular}




\begin{tabular}{|c|c|c|c|c|c|}
\hline $\begin{array}{l}\text { Author(s) } \\
\text { (Year) }\end{array}$ & $\begin{array}{l}\text { Research } \\
\text { Stream } \\
\end{array}$ & Focus & $\begin{array}{l}\text { Theoretical } \\
\text { Lens }\end{array}$ & Methodology & Key Findings related to the CHQ \\
\hline Ohmae (1989) & $\mathrm{MNF}$ & $\begin{array}{l}\text { Env. context; } \\
\text { org. context; } \\
\text { location }\end{array}$ & $\begin{array}{l}\text { Managerial/ } \\
\text { normative; } \\
\text { contingency } \\
\text { theory (implicit) }\end{array}$ & $\begin{array}{l}\text { Conceptual/ } \\
\text { illustrative } \\
\text { examples }\end{array}$ & $\begin{array}{l}\text { Globally operating firms cannot centralize all key decision; thus, firms } \\
\text { should decompose the CHQ into several RHQ. In addition, } \\
\text { corporations should make sure their widespread managers have a } \\
\text { shared identity, which comes from instilling a shared set of values. }\end{array}$ \\
\hline $\begin{array}{l}\text { Greenwood, } \\
\text { Hinings, \& } \\
\text { Brown (1990) }\end{array}$ & $\mathrm{MBF}$ & $\begin{array}{l}\text { Org. context } \\
\text { (CSS); roles/ } \\
\text { functions }\end{array}$ & Control theory & $\begin{array}{l}\text { Qual. and quant.; } \\
\text { large US } \\
\text { accounting firms }\end{array}$ & $\begin{array}{l}\text { Compared to } \mathrm{M} \text {-form and holding companies, the CHQ in professional } \\
\text { partnerships }\left(\mathrm{P}^{2} \text {-form) differs along three control dimensions: strategic, }\right. \\
\text { market-financial and operating control. }\end{array}$ \\
\hline Chandler (1991) & $\mathrm{MBF}$ & $\begin{array}{l}\text { Roles/ activities; } \\
\text { env. context; org. } \\
\text { context }\end{array}$ & $\begin{array}{l}\text { Organizational } \\
\text { contingency } \\
\text { theory }\end{array}$ & $\begin{array}{l}\text { Conceptual/ } \\
\text { illustrative cases } \\
\text { (IBM, GE, } \\
\text { DuPont) } \\
\end{array}$ & $\begin{array}{l}\text { The CHQ performs two basic functions: (1) entrepreneurial (value- } \\
\text { creation, strategic planning) and (2) administrative (loss prevention, } \\
\text { financial control). In industries in which MBF have few advantages } \\
\text { over other firms, the CHQ should only undertake financial controls. }\end{array}$ \\
\hline $\begin{array}{l}\text { Gupta \& } \\
\text { Govindarajan } \\
(1991)\end{array}$ & MNF & $\begin{array}{l}\text { CHQ-sub } \\
\text { relations; } \\
\text { operating units }\end{array}$ & $\begin{array}{l}\text { Control theory; } \\
\text { knowledge flows }\end{array}$ & Conceptual & $\begin{array}{l}\text { This article proposes that within the same corporation, the nature of } \\
\text { control mechanism used by the CHQ varies across subsidiaries due to } \\
\text { differences in subsidiary contexts: the extent to which the subsidiary is } \\
\text { (a) a user and (b) a provider of knowledge from/to the rest of the firm. }\end{array}$ \\
\hline Howard (1991) & MNF & $\begin{array}{l}\text { Org. context } \\
\text { (GSS); roles/ } \\
\text { activities; } \\
\text { operating units }\end{array}$ & $\begin{array}{l}\text { Managerial/ } \\
\text { normative }\end{array}$ & $\begin{array}{l}\text { Single case study } \\
\text { of Italian } \\
\text { manufacturer } \\
\text { Gruppo GFT }\end{array}$ & $\begin{array}{l}\text { The more a firm penetrates global markets, the more it has to respond } \\
\text { to a myriad local differences between those markets: The periphery has } \\
\text { to become the center of the management's attention and the CHQ's } \\
\text { key role is to manage the continuous redesign of the overall firm. }\end{array}$ \\
\hline $\begin{array}{l}\text { Alexander } \\
(1992)\end{array}$ & $\mathrm{MBF}$ & $\begin{array}{l}\text { Roles/ activities; } \\
\text { design; resources }\end{array}$ & $\begin{array}{l}\text { Managerial/ } \\
\text { normative }\end{array}$ & $\begin{array}{l}\text { Conceptual/ } \\
\text { illustrative } \\
\text { examples }\end{array}$ & $\begin{array}{l}\text { The CHQ serves as an intermediate between shareholders and business } \\
\text { unit managers in a corporate portfolio. Beyond risk reduction, each } \\
\text { CHQ needs to define the potential scope of its role by considering its } \\
\text { particular corporate capabilities to play this role. }\end{array}$ \\
\hline $\begin{array}{l}\text { Barton, Brown, } \\
\text { Cound, Marsh, } \\
\text { \& Willey (1992) }\end{array}$ & $\mathrm{MBF}$ & $\begin{array}{l}\text { Roles/ activities; } \\
\text { integrating } \\
\text { mechanisms; } \\
\text { CHQ outcomes }\end{array}$ & $\begin{array}{l}\text { Control theory; } \\
\text { parenting theory }\end{array}$ & $\begin{array}{l}\text { Survey of } 100 \\
\text { divisionalized } \\
\text { UK firms, } 1989\end{array}$ & $\begin{array}{l}\text { A comparison of the divisional perceptions of investment decision- } \\
\text { making processes with CHQ perceptions reveals that the behavior of } \\
\text { the CHQ could be leading to internally generated short-termism, and } \\
\text { myopic underinvestment in the British industry. }\end{array}$ \\
\hline $\begin{array}{l}\text { Hill, Hitt, \& } \\
\text { Hoskisson } \\
\text { (1992) }\end{array}$ & $\mathrm{MBF}$ & $\begin{array}{l}\text { Org. context } \\
\text { (CSS); outcomes; } \\
\text { integrating } \\
\text { mechanisms }\end{array}$ & $\begin{array}{l}\text { Organizational } \\
\text { contingency } \\
\text { theory }\end{array}$ & $\begin{array}{l}\text { Survey of } 184 \\
\text { Fortune } 1,000 \\
\text { firms }\end{array}$ & $\begin{array}{l}\text { A fit between diversification strategy, organization structure, and CHQ } \\
\text { control systems explains superior performance. A design that aims at } \\
\text { the exploitation of economies of scope needs cooperation between Bus, } \\
\text { whereas efficient internal governance needs competition between BUs. }\end{array}$ \\
\hline $\begin{array}{l}\text { Roth \& Nigh } \\
\text { (1992) }\end{array}$ & MNF & $\begin{array}{l}\text { Integrating } \\
\text { mechanisms; } \\
\text { operating units; } \\
\text { outcomes }\end{array}$ & $\begin{array}{l}\text { Transaction cost } \\
\text { economics }\end{array}$ & $\begin{array}{l}\text { Survey of } 105 \\
\text { foreign } \\
\text { subsidiaries in } \\
\text { the US }\end{array}$ & $\begin{array}{l}\text { The coordination of primary activities and personal integrating } \\
\text { mechanisms (i.e. behavioral control) positively influence the } \\
\text { effectiveness of the CHQ-subsidiary relationship, while conflict affects } \\
\text { it negatively. }\end{array}$ \\
\hline
\end{tabular}




\begin{tabular}{|c|c|c|c|c|c|}
\hline $\begin{array}{l}\text { Author(s) } \\
\text { (Year) }\end{array}$ & $\begin{array}{l}\text { Research } \\
\text { Stream }\end{array}$ & Focus & \begin{tabular}{|l|} 
Theoretical \\
Lens
\end{tabular} & Methodology & Key Findings related to the CHQ \\
\hline Russo (1992) & MBF & $\begin{array}{l}\text { Env. context; } \\
\text { integrating m.; } \\
\text { operting units; } \\
\text { outcomes }\end{array}$ & $\begin{array}{l}\text { Transaction cost } \\
\text { economics }\end{array}$ & $\begin{array}{l}\text { Quant. analysis: } \\
\text { subsidiaries of } 54 \\
\text { US electric } \\
\text { utilities } 1966-86\end{array}$ & $\begin{array}{l}\text { There is a connection between the characteristics of the regulated } \\
\text { parent company and subsidiary performance. Intense regulatory } \\
\text { oversight affects new venture performance negatively. }\end{array}$ \\
\hline $\begin{array}{l}\text { Hungenberg } \\
\text { (1993) }\end{array}$ & MBF & $\begin{array}{l}\text { Roles/ activities; } \\
\text { integrating } \\
\text { mechanisms; } \\
\text { operating units }\end{array}$ & $\begin{array}{l}\text { Managerial (no } \\
\text { explicit } \\
\text { theoretical lens) }\end{array}$ & $\begin{array}{l}\text { Conceptual/ } \\
\text { illustrative case } \\
\text { (Daimler-Benz) }\end{array}$ & $\begin{array}{l}\text { The CHQ adds value by defining the business portfolio and by } \\
\text { coordinating the portfolio. The CHQ role and some moderating factors } \\
\text { influence the intensity of CHQ intervention on the business level } \\
\text { decision-making process and the extent of cross-business coordination. }\end{array}$ \\
\hline $\begin{array}{l}\text { Markides \& } \\
\text { Williamson } \\
\text { (1994) }\end{array}$ & MBF & $\begin{array}{l}\text { Resources; org. } \\
\text { context (CSS); } \\
\text { outcomes }\end{array}$ & $\begin{array}{l}\text { Resource-based } \\
\text { view }\end{array}$ & $\begin{array}{l}\text { Quant. analysis: } \\
164 \text { Fortune } 500 \\
\text { firms }\end{array}$ & $\begin{array}{l}\text { Firms with CHQs that enable the sharing of similar opportunities } \\
\text { (related to brand building, marketing and channel management, } \\
\text { process skills in customization, and the management of skilled teams) } \\
\text { profit from related diversification. }\end{array}$ \\
\hline $\begin{array}{l}\text { Nohria \& } \\
\text { Ghoshal (1994) }\end{array}$ & MNF & $\begin{array}{l}\text { CHQ-subsidiary } \\
\text { relations; } \\
\text { outcomes }\end{array}$ & $\begin{array}{l}\text { Equifinality; } \\
\text { differentiated fit; } \\
\text { shared values }\end{array}$ & $\begin{array}{l}54 \text { MNCs in } \\
\text { North America } \\
\text { and Europe with } \\
\text { 5+ subsidiaries }\end{array}$ & $\begin{array}{l}\text { 'Differentiated fit' (differentiated formal structures of CHQ-subsidiary } \\
\text { relations to fit the contexts of its subsidiaries) and 'shared values' are } \\
\text { two equally effective ways to manage CHQ-subsidiary relations, but } \\
\text { using both simultaneously leads to the best relative performance. }\end{array}$ \\
\hline $\begin{array}{l}\text { Berger \& Ofek } \\
(1995)\end{array}$ & MBF & $\begin{array}{l}\text { Outcomes; org. } \\
\text { context (CSS); } \\
\text { roles/ activities }\end{array}$ & $\begin{array}{l}\text { Financial } \\
\text { economics } \\
\text { (efficient market } \\
\text { hypothesis) }\end{array}$ & $\begin{array}{l}\text { Longitudinal } \\
\text { study of } 3,659 \\
\text { US firms (1986- } \\
91 \text {, archival data) }\end{array}$ & $\begin{array}{l}\text { Diversification reduces the value of the MBF by an average of 13- } \\
15 \% \text {, independent of firm size, and less in related diversifying firms. } \\
\text { The value loss can be partly attributed to the CHQ, since } \\
\text { overinvestment and cross-subsidization reduce value, which is partly } \\
\text { mitigated by tax benefits. }\end{array}$ \\
\hline Campbell (1995) & MBF & $\begin{array}{l}\text { Integrating } \\
\text { mechanisms; } \\
\text { resources; } \\
\text { operating units }\end{array}$ & $\begin{array}{l}\text { Managerial/ } \\
\text { normative } \\
\text { (parenting } \\
\text { theory) }\end{array}$ & $\begin{array}{l}\text { Illustrative; } 15 \\
\text { firms (e.g., GE, } \\
\text { Canon, 3M, } \\
\text { Shell) }\end{array}$ & $\begin{array}{l}\text { A vertical integration strategy requires three conditions: (1) the BU } \\
\text { must have the potential to improve its performance or its relationship } \\
\text { with its sister companies; (2) the CHQ must possess skills or resources } \\
\text { needed to help the BU; (3) the CHQ must understand the business well } \\
\text { enough. }\end{array}$ \\
\hline $\begin{array}{l}\text { Campbell, } \\
\text { Goold, \& } \\
\text { Alexander } \\
\text { (1995a) }\end{array}$ & MBF & $\begin{array}{l}\text { Roles/ activities; } \\
\text { resources; } \\
\text { outcomes }\end{array}$ & $\begin{array}{l}\text { Managerial/ } \\
\text { normative } \\
\text { (parenting } \\
\text { theory) }\end{array}$ & $\begin{array}{l}\text { Conceptual, } \\
\text { illustrative cases }\end{array}$ & $\begin{array}{l}\text { Instead of looking at how businesses relate to one another, the CHQ } \\
\text { should look at how well its skills fit its businesses' needs and whether } \\
\text { owning them creates or destroys value. }\end{array}$ \\
\hline $\begin{array}{l}\text { Campbell, } \\
\text { Goold, \& } \\
\text { Alexander } \\
(1995 b)\end{array}$ & MBF & $\begin{array}{l}\text { Roles/ activities; } \\
\text { outcomes }\end{array}$ & $\begin{array}{l}\text { Managerial/ } \\
\text { normative } \\
\text { (parenting } \\
\text { theory) }\end{array}$ & $\begin{array}{l}\text { Conceptual/ } \\
\text { illustrative cases } \\
\text { (ABB, Canon, } \\
\text { Emerson) }\end{array}$ & $\begin{array}{l}\text { The CHQ can add (or destroy) value in four different ways: (1) stand- } \\
\text { alone influence (impact on businesses' strategy), (2) linkage influence } \\
\text { (fostering cooperation between businesses), (3) central functions and } \\
\text { services, and (4) corporate development (M\&A, alliances, etc.). }\end{array}$ \\
\hline $\begin{array}{l}\text { Ferlie \& } \\
\text { Pettigrew (1996) }\end{array}$ & MBF & $\begin{array}{l}\text { Design; } \\
\text { outcomes }\end{array}$ & Multiple theories & $\begin{array}{l}\text { Conceptual } \\
\text { review }\end{array}$ & $\begin{array}{l}\text { CHQ-level change (especially downsizing) was an increasingly } \\
\text { important phenomenon in the late 1980s and early 1990s. }\end{array}$ \\
\hline
\end{tabular}




\begin{tabular}{|c|c|c|c|c|c|}
\hline $\begin{array}{l}\text { Author(s) } \\
\text { (Year) }\end{array}$ & $\begin{array}{l}\text { Research } \\
\text { Stream } \\
\end{array}$ & Focus & \begin{tabular}{|l|} 
Theoretical \\
Lens
\end{tabular} & Methodology & Key Findings related to the CHQ \\
\hline Goold (1996a) & MBF & $\begin{array}{l}\text { Resources; } \\
\text { outcomes }\end{array}$ & $\begin{array}{l}\text { Managerial/ } \\
\text { normative } \\
\text { (parenting } \\
\text { theory) }\end{array}$ & $\begin{array}{l}\text { Conceptual; } \\
\text { qualitative } \\
\text { analysis of } \\
\text { several cases }\end{array}$ & $\begin{array}{l}\text { A focus on opportunities to add value, and on the distinctive resources } \\
\text { that the CHQ possesses and that lead to added value, provides the basis } \\
\text { for valid corporate strategies. }\end{array}$ \\
\hline Goold (1996b) & MBF & $\begin{array}{l}\text { Roles/ activities; } \\
\text { integrating } \\
\text { mechanisms; } \\
\text { operating units }\end{array}$ & $\begin{array}{l}\text { Managerial/ } \\
\text { normative } \\
\text { (parenting } \\
\text { theory) }\end{array}$ & $\begin{array}{l}\text { Conceptual; } \\
\text { qualitative } \\
\text { analysis of } \\
\text { several cases }\end{array}$ & $\begin{array}{l}\text { Instead of paying less attention and providing fewer resources, the } \\
\text { CHQ should develop a constructive, added-value relationship with the } \\
\text { mature businesses focused on lean operations, capacity closure, } \\
\text { influencing the investment decision, price and margin, and } \\
\text { rejuvenation. }\end{array}$ \\
\hline $\begin{array}{l}\text { Markides \& } \\
\text { Williamson } \\
\text { (1996) }\end{array}$ & MBF & $\begin{array}{l}\text { Org. context; } \\
\text { integrating } \\
\text { mechanisms; } \\
\text { outcomes }\end{array}$ & $\begin{array}{l}\text { Resource-based } \\
\text { view }\end{array}$ & $\begin{array}{l}\text { Quant. analysis: } \\
\text { survey of } 136 \\
\text { large US firms }\end{array}$ & $\begin{array}{l}\text { Related diversification strategies are only beneficial when the CHQ } \\
\text { grants the businesses preferential access to strategic assets. } \\
\text { Competences to develop new strategic assets faster and more } \\
\text { efficiently than competitors are a source of long-term superior } \\
\text { performance. }\end{array}$ \\
\hline $\begin{array}{l}\text { Roth \& } \\
\text { O’Donnell } \\
(1996)\end{array}$ & MNF & $\begin{array}{l}\text { CHQ-subsidiary } \\
\text { relations; } \\
\text { operating units, } \\
\text { outcomes }\end{array}$ & Agency theory & $\begin{array}{l}100 \text { subsidiaries } \\
\text { in five countries }\end{array}$ & $\begin{array}{l}\text { The agency problem, defined by the subsidiary's cultural distance from } \\
\text { its CHQ market, lateral centralization, and TMT commitment to the } \\
\text { CHQ, influences the compensation strategy. The incentive structure- } \\
\text { agency state alignment is positively related to subsidiary effectiveness. }\end{array}$ \\
\hline $\begin{array}{l}\text { Tan \& Vertinsky } \\
\text { (1996) }\end{array}$ & MNF & $\begin{array}{l}\text { Resources; } \\
\text { outcomes }\end{array}$ & $\begin{array}{l}\text { Internationalizati } \\
\text { on theory }\end{array}$ & $\begin{array}{l}\text { Survey of } 262 \\
\text { Japanese } \\
\text { electronics firms }\end{array}$ & $\begin{array}{l}\text { Size and financial capabilities, as well as the possession of knowledge- } \\
\text { based, firm-specific strategic assets are significantly related to early } \\
\text { FDI. Specifically, CHQ attributes that facilitate market intelligence } \\
\text { capabilities allow early recognition of investment opportunities }\end{array}$ \\
\hline $\begin{array}{l}\text { Collis \& } \\
\text { Montgomery } \\
(1997)\end{array}$ & MBF & $\begin{array}{l}\text { Roles/ activities; } \\
\text { resources; } \\
\text { outcomes }\end{array}$ & $\begin{array}{l}\text { Resource-based } \\
\text { view }\end{array}$ & $\begin{array}{l}\text { Conceptual/ } \\
\text { illustrative cases }\end{array}$ & $\begin{array}{l}\text { The CHQ performs four roles: (1) formulates and communicates a } \\
\text { firm's strategy, (2) allocates valuable resources, (3) fulfills general } \\
\text { overhead functions, and (4) sets administrative context by choosing the } \\
\text { structure, systems, and control processes and by achieving coherence. }\end{array}$ \\
\hline Foss (1997) & MBF & Roles/ activities & $\begin{array}{l}\text { Resource-based } \\
\text { view; transaction } \\
\text { cost economics }\end{array}$ & $\begin{array}{l}\text { Conceptual/ } \\
\text { deductive theory- } \\
\text { building }\end{array}$ & $\begin{array}{l}\text { The CHQ should perform two mechanisms: (1) knowledge-direction } \\
\text { ('initiating intra-firm learning processes') and (2) the exploitation of } \\
\text { 'flexibility' (e.g., altering responsibilities of business managers, } \\
\text { changing/coordinating the business portfolio). }\end{array}$ \\
\hline $\begin{array}{l}\text { Collis \& } \\
\text { Montgomery } \\
(1998)\end{array}$ & MBF & $\begin{array}{l}\text { Org. context; } \\
\text { design; } \\
\text { integrating m.; } \\
\text { outcomes }\end{array}$ & $\begin{array}{l}\text { Resource-based } \\
\text { view }\end{array}$ & $\begin{array}{l}\text { Conceptual; } \\
\text { illustrative cases } \\
\text { (Newell, Sharp, } \\
\text { Tyco) }\end{array}$ & $\begin{array}{l}\text { Firms should tailor their organizational structures and systems to the } \\
\text { needs of their particular strategy, instead of creating plain-vanilla } \\
\text { CHQs and infrastructures. }\end{array}$ \\
\hline Pettifer (1998) & MBF & $\begin{array}{l}\text { Roles/ activities; } \\
\text { outcomes }\end{array}$ & $\begin{array}{l}\text { Managerial/ } \\
\text { normative }\end{array}$ & $\begin{array}{l}\text { Conceptual/ } \\
\text { illustrative } \\
\text { examples }\end{array}$ & $\begin{array}{l}\text { Three distinct CHQ activities require diverse perf. measures: (1) core } \\
\text { activities are mostly predictable, repetitive and can be benchmarked; } \\
\text { (2) value adding is less repetitive and less bench-markable; }(3) \text { shared } \\
\text { services are targeted at covering their cost of capital. }\end{array}$ \\
\hline
\end{tabular}




\begin{tabular}{|c|c|c|c|c|c|}
\hline $\begin{array}{l}\text { Author(s) } \\
\text { (Year) }\end{array}$ & $\begin{array}{l}\text { Research } \\
\text { Stream }\end{array}$ & Focus & \begin{tabular}{|l|} 
Theoretical \\
Lens
\end{tabular} & Methodology & Key Findings related to the CHQ \\
\hline $\begin{array}{l}\text { Scharfstein } \\
\text { (1998) }\end{array}$ & MBF & Org. context & $\begin{array}{l}\text { Financial } \\
\text { economics } \\
\text { (efficient market } \\
\text { hypothesis) }\end{array}$ & $\begin{array}{l}\text { Longitudinal } \\
\text { study of } 165 \text { US } \\
\text { conglomerates, } \\
1979-94\end{array}$ & $\begin{array}{l}\text { Highly diversified firms tend to overinvest in businesses with poor } \\
\text { investment prospects and tend to underinvest in those with promising } \\
\text { prospects, which indicates agency problems between the CHQ and } \\
\text { investors, especially in firms in which the management has small } \\
\text { equity stakes. }\end{array}$ \\
\hline Young (1998a) & MBF & $\begin{array}{l}\text { Design; } \\
\text { operating units }\end{array}$ & $\begin{array}{l}\text { Managerial/ } \\
\text { normative }\end{array}$ & $\begin{array}{l}\text { Conceptual; } \\
\text { survey based data }\end{array}$ & $\begin{array}{l}\text { The number of CHQ staff and functions depends on the CHQ's role. } \\
\text { Corporate managers find it easier to add value if the businesses in their } \\
\text { portfolios have similar products, produced by using similar } \\
\text { technologies and sold to similar customer bases. }\end{array}$ \\
\hline Campbell (1999) & MBF & $\begin{array}{l}\text { Outcomes; } \\
\text { operating units }\end{array}$ & $\begin{array}{l}\text { Managerial/ } \\
\text { normative }\end{array}$ & $\begin{array}{l}\text { Conceptual/ } \\
\text { illustrative cases } \\
\text { (Granada, Dow, } \\
\text { Emerson) }\end{array}$ & $\begin{array}{l}\text { The CHQ can destroy value by poor corporate planning (it can cause } \\
\text { business professionals to waste time and money, send the wrong } \\
\text { signals to managers, and lead managers to follow bad advice) and } \\
\text { CHQ staff must thus manage their involvement carefully. }\end{array}$ \\
\hline Kono (1999) & MBF & $\begin{array}{l}\text { Roles/ activities; } \\
\text { org. context } \\
(\mathrm{CSS}) \text {; design }\end{array}$ & $\begin{array}{l}\text { Organizational } \\
\text { contingency } \\
\text { theory }\end{array}$ & $\begin{array}{l}\text { Quant. analysis: } \\
\text { survey of } 97 \\
\text { Japanese firms }\end{array}$ & $\begin{array}{l}\text { The CHQ has three functions: (1) development of the corporate } \\
\text { strategy, (2) expert staff assistance to develop strong core } \\
\text { competencies, and (3) providing centralized services; related } \\
\text { diversifiers tend to have a larger CHQ than unrelated firms. }\end{array}$ \\
\hline $\begin{array}{l}\text { O’Donnell } \\
(2000)\end{array}$ & MNF & $\begin{array}{l}\text { CHQ-subsidiary } \\
\text { relations; } \\
\text { integrating } \\
\text { mechanism }\end{array}$ & $\begin{array}{l}\text { Agency theory; } \\
\text { intra-firm } \\
\text { interdependence } \\
\text { (social controls) } \\
\end{array}$ & $\begin{array}{l}\text { US-based MNFs; } \\
\text { primary and } \\
\text { secondary data } \\
\text { analyses }\end{array}$ & $\begin{array}{l}\text { Suggests that agency theory, although a useful foundation for studies } \\
\text { of control within MNFs, is limited in its ability to fully explain the } \\
\text { phenomenon of foreign subsidiary control; however, the model based } \\
\text { on intra-firm interdependence had much greater predictive ability. }\end{array}$ \\
\hline $\begin{array}{l}\text { Scharfstein \& } \\
\text { Stein }(2000)\end{array}$ & MBF & $\begin{array}{l}\text { Operating units, } \\
\text { outcomes }\end{array}$ & $\begin{array}{l}\text { Financial } \\
\text { economics } \\
\text { (efficient market } \\
\text { hypothesis) }\end{array}$ & Theory building & $\begin{array}{l}\text { BU managers' rent-seeking behavior can subvert the internal capital } \\
\text { market: By rent seeking, BU managers can raise their bargaining } \\
\text { power and extract greater compensation from the CEO, which may } \\
\text { take the form of preferential capital budgeting allocations. }\end{array}$ \\
\hline $\begin{array}{l}\text { Van Oijen \& } \\
\text { Douma (2000) }\end{array}$ & MBF & $\begin{array}{l}\text { Outcomes; org. } \\
\text { context; design }\end{array}$ & $\begin{array}{l}\text { Organizational } \\
\text { contingency } \\
\text { theory }\end{array}$ & $\begin{array}{l}\text { Survey of } 67 \\
\text { listed Dutch } \\
\text { firms }\end{array}$ & $\begin{array}{l}\text { High-performing MBF have a better fit between the diversification } \\
\text { strategy and the CHQ roles than low performing MBF; they align the } \\
\text { planning, evaluation, selection, motivation, and support roles with the } \\
\text { diversification strategy, but not job rotation and coordination. }\end{array}$ \\
\hline $\begin{array}{l}\text { Birkinshaw \& } \\
\text { Hood (2001) }\end{array}$ & MNF & $\begin{array}{l}\text { Outcomes; } \\
\text { integrating } \\
\text { mechanisms; } \\
\text { operating units }\end{array}$ & $\begin{array}{l}\text { Managerial/ } \\
\text { normative }\end{array}$ & $\begin{array}{l}\text { Qualitative } \\
\text { analysis; more } \\
\text { than } 50 \mathrm{MNFs}\end{array}$ & $\begin{array}{l}\text { Formal and informal communication between the CHQ and its } \\
\text { subsidiaries foster subsidiary innovation: the CHQ can provide seed } \\
\text { money; use formal requests to increase demand for seed money; } \\
\text { encourage subsidiaries to be incubators for fledgling businesses; build } \\
\text { international networks. }\end{array}$ \\
\hline $\begin{array}{l}\text { Darragh \& } \\
\text { Campbell (2001) }\end{array}$ & MBF & Outcomes & $\begin{array}{l}\text { Managerial (no } \\
\text { explicit } \\
\text { theoretical lens) }\end{array}$ & $\begin{array}{l}\text { Qualitative } \\
\text { analysis of } 28 \\
\text { corporate } \\
\text { initiatives }\end{array}$ & $\begin{array}{l}\text { While corporate initiatives are the main vehicle through which the } \\
\text { CHQ creates additional value in its portfolio of businesses, many of } \\
\text { them become stuck. Nine root causes can help diagnose why a } \\
\text { corporate initiatives has become stuck. }\end{array}$ \\
\hline
\end{tabular}




\begin{tabular}{|c|c|c|c|c|c|}
\hline $\begin{array}{l}\text { Author(s) } \\
\text { (Year) }\end{array}$ & $\begin{array}{l}\text { Research } \\
\text { Stream }\end{array}$ & Focus & $\begin{array}{l}\text { Theoretical } \\
\text { Lens }\end{array}$ & Methodology & Key Findings related to the CHQ \\
\hline $\begin{array}{l}\text { Goold, Pettifer, } \\
\& \text { Young }(2001)\end{array}$ & MBF & $\begin{array}{l}\text { Roles/ activities; } \\
\text { resources; design }\end{array}$ & $\begin{array}{l}\text { Managerial (no } \\
\text { explicit } \\
\text { theoretical lens) }\end{array}$ & $\begin{array}{l}\text { Conceptual/ } \\
\text { descriptive } \\
\text { survey results/ } \\
\text { illustrative cases }\end{array}$ & $\begin{array}{l}\text { Three different CHQ roles - (1) minimum CHQ (legal and regulatory } \\
\text { obligations), (2) value-added CHQ (infl. on businesses, closely related } \\
\text { to corporate strategy), and ( } 3 \text { ) shared services, - need different } \\
\text { competencies and justify certain CHQ staff. }\end{array}$ \\
\hline $\begin{array}{l}\text { Jacque \& Vaaler } \\
\text { (2001) }\end{array}$ & MNF & $\begin{array}{l}\text { Outcomes; env. } \\
\text { context }\end{array}$ & $\begin{array}{l}\text { Agency theory/ } \\
\text { control theory }\end{array}$ & Conceptual & $\begin{array}{l}\text { To avoid principle-agent problems between the CHQ and subsidiaries } \\
\text { due to exchange rate fluctuations, a single EVA-based measure can } \\
\text { help assess and compare subsidiary performance in emerging-market } \\
\text { countries in the presence of unexpected, exchange-related shocks. }\end{array}$ \\
\hline $\begin{array}{l}\text { Raynor \& Bower } \\
\text { (2001) }\end{array}$ & MBF & $\begin{array}{l}\text { Roles/ activities; } \\
\text { env. context; } \\
\text { operating units }\end{array}$ & $\begin{array}{l}\text { Managerial/ } \\
\text { normative (no } \\
\text { explicit } \\
\text { theoretical lens) }\end{array}$ & $\begin{array}{l}\text { Conceptual/ four } \\
\text { illustrative cases } \\
\text { (WPP, Teradyne, } \\
\text { Sprint, Viacom) }\end{array}$ & $\begin{array}{l}\text { The CHQ should be more directive in turbulent markets and play an } \\
\text { active role in defining the scope of the division-level strategy. } \\
\text { Adopting a dynamic approach to cooperation between BUs enables } \\
\text { varying degrees of relatedness between them, depending on strategic } \\
\text { circumstances. }\end{array}$ \\
\hline $\begin{array}{l}\text { Rugman \& } \\
\text { Verbeke (2001) }\end{array}$ & MNF & $\begin{array}{l}\text { Resources/capabi } \\
\text { lities/org. context } \\
\text { (GSS) }\end{array}$ & $\begin{array}{l}\text { Resource-based } \\
\text { view; } \\
\text { international } \\
\text { perspective }\end{array}$ & Conceptual & $\begin{array}{l}\text { A new framework summarizes } 10 \text { types of MNF-subsidiary linkages } \\
\text { leading to capability development, of which several are associated with } \\
\text { subsidiary-specific advantages. }\end{array}$ \\
\hline Batten (2002) & MBF & $\begin{array}{l}\text { Resources; } \\
\text { outcomes }\end{array}$ & $\begin{array}{l}\text { Managerial/ } \\
\text { resource-based } \\
\text { view (no explicit } \\
\text { theoretical lens) } \\
\end{array}$ & $\begin{array}{l}\text { Illustrative case } \\
\text { study }\end{array}$ & $\begin{array}{l}\text { The CHQ's attitude and resources (e.g., capital, management talent, } \\
\text { and experience in related fields) are critical for successful corporate } \\
\text { entrepreneurship. }\end{array}$ \\
\hline $\begin{array}{l}\text { Goold \& } \\
\text { Campbell } \\
(2002 a)\end{array}$ & MBF & $\begin{array}{l}\text { Org. context; } \\
\text { design; outcomes }\end{array}$ & $\begin{array}{l}\text { Managerial/ } \\
\text { normative } \\
\text { (parenting } \\
\text { theory) }\end{array}$ & $\begin{array}{l}\text { Conceptual; } \\
\text { illustrative cases }\end{array}$ & $\begin{array}{l}\text { A systematic approach (nine tests) should be used to evaluate an } \\
\text { existing organization design or create a new one. The tests help the } \\
\text { CHQ's managers create parenting advantage. }\end{array}$ \\
\hline $\begin{array}{l}\text { Goold \& } \\
\text { Campbell } \\
(2002 b)\end{array}$ & MBF & $\begin{array}{l}\text { Org. context } \\
\text { (CSS); outcomes }\end{array}$ & $\begin{array}{l}\text { Managerial/ } \\
\text { normative } \\
\text { (parenting } \\
\text { theory) }\end{array}$ & $\begin{array}{l}\text { Qualitative } \\
\text { analysis of large } \\
\text { companies and } \\
\text { smaller firms }\end{array}$ & $\begin{array}{l}\text { There are some special parenting challenges in complex structures, but } \\
\text { the quest for 'parenting advantage' should remain a fundamental driver } \\
\text { of corporate strategy and structure. }\end{array}$ \\
\hline Markides (2002) & MBF & Roles/ activities & $\begin{array}{l}\text { Transaction } \\
\text { costs; learning }\end{array}$ & Conceptual & $\begin{array}{l}\text { The CHQ's role relates directly to the economic rationale for the } \\
\text { existence of the MBF, which is threefold: (1) exploit economies of } \\
\text { scope, (2) benefit from efficient internal capital markets, and (3) foster } \\
\text { sharing of knowledge across BUs to create new strategic assets. }\end{array}$ \\
\hline Song (2002) & MNF & $\begin{array}{l}\text { Resources; } \\
\text { outcomes }\end{array}$ & $\begin{array}{l}\text { Capability-based } \\
\text { view }\end{array}$ & $\begin{array}{l}\text { Quant. analysis: } \\
\text { 128 Electronics } \\
\text { companies; Japan } \\
1988-94\end{array}$ & $\begin{array}{l}\text { In addition to the importance of capabilities at the host country and at } \\
\text { the local subsidiary levels, CHQ capabilities play an important role in } \\
\text { sequential foreign investment decisions. }\end{array}$ \\
\hline
\end{tabular}




\begin{tabular}{|c|c|c|c|c|c|}
\hline $\begin{array}{l}\text { Author(s) } \\
\text { (Year) }\end{array}$ & $\begin{array}{l}\text { Research } \\
\text { Stream }\end{array}$ & Focus & $\begin{array}{l}\text { Theoretical } \\
\text { Lens }\end{array}$ & Methodology & Key Findings related to the CHQ \\
\hline $\begin{array}{l}\text { Adner \& Helfat } \\
(2003)\end{array}$ & $\mathrm{MBF}$ & $\begin{array}{l}\text { Resources; } \\
\text { outcomes }\end{array}$ & $\begin{array}{l}\text { Dynamic } \\
\text { capabilities view }\end{array}$ & $\begin{array}{l}\text { Longitudinal } \\
\text { study of } 30 \text { US } \\
\text { petroleum indus- } \\
\text { try firms; } 1977-97 \\
\end{array}$ & $\begin{array}{l}\text { Differences between CHQ managerial decisions partly explain } \\
\text { performance heterogeneity. Dynamic managerial capabilities and the } \\
\text { underlying attributes (human capital, social capital, and managerial } \\
\text { cognition) explain how CHQ managers cope with env. changes. }\end{array}$ \\
\hline $\begin{array}{l}\text { Bowman \& } \\
\text { Ambrosini } \\
(2003)\end{array}$ & $\mathrm{MBF}$ & $\begin{array}{l}\text { Resources; org. } \\
\text { context }\end{array}$ & $\begin{array}{l}\text { Dynamic } \\
\text { capabilities view }\end{array}$ & Conceptual & $\begin{array}{l}\text { Six CHQ resource creation configurations stem from six modes of } \\
\text { CHQ resource creation - reconfig. of supp. activities, reconfig. of core } \\
\text { processes, leverage of avail. resources, encouraged learning, provoked } \\
\text { learning, and creative integration - and org. design parameters. }\end{array}$ \\
\hline $\begin{array}{l}\text { Miller \& Waller } \\
(2003)\end{array}$ & $\mathrm{MBF}$ & $\begin{array}{l}\text { Roles/ activities; } \\
\text { design; outcomes }\end{array}$ & $\begin{array}{l}\text { Real option } \\
\text { theory }\end{array}$ & Conceptual & $\begin{array}{l}\text { Combining scenario planning and real option analysis in an integrated } \\
\text { risk management process helps CHQ managers consider the full range } \\
\text { of exposures across a firm's portfolio of businesses. }\end{array}$ \\
\hline Poppo (2003) & MBF & $\begin{array}{l}\text { Integrating } \\
\text { mechanisms; } \\
\text { operating units; } \\
\text { outcomes }\end{array}$ & $\begin{array}{l}\text { Transaction cost } \\
\text { economics; } \\
\text { strategy literature }\end{array}$ & $\begin{array}{l}\text { Survey of corp. } \\
\text { managers of } \\
\text { Fortune } 500 \\
\text { firms }\end{array}$ & $\begin{array}{l}\text { Corp. staff are more likely to involve themselves in business-level } \\
\text { decisions regarding uncertain products; when corp. staff are } \\
\text { responsible for the capital investments used for the divisional venture, } \\
\text { they are more likely to guide and infl. product strategy decisions and } \\
\text { inter-divisional conflicts. }\end{array}$ \\
\hline $\begin{array}{l}\text { Kaplan \& } \\
\text { Norton (2005) }\end{array}$ & MBF & $\begin{array}{l}\text { Design; } \\
\text { outcomes }\end{array}$ & $\begin{array}{l}\text { Managerial (no } \\
\text { explicit } \\
\text { theoretical lens) }\end{array}$ & $\begin{array}{l}\text { Conceptual/ } \\
\text { illustrative } \\
\text { examples }\end{array}$ & $\begin{array}{l}\text { A corporate-level unit can help oversee all activities related to strategy } \\
\text { (a strategy management office, OSM) and, thus, sustain a strategic } \\
\text { focus. }\end{array}$ \\
\hline Stalk (2005) & MBF & $\begin{array}{l}\text { Roles/ activities; } \\
\text { design }\end{array}$ & $\begin{array}{l}\text { Managerial (no } \\
\text { explicit } \\
\text { theoretical lens) }\end{array}$ & $\begin{array}{l}\text { Conceptual/ } \\
\text { illustrative } \\
\text { examples }\end{array}$ & $\begin{array}{l}\text { The CHQ should be lean, but not so small as to be ineffective. Active } \\
\text { CHQs can have a positive impact on subsidiaries, as they can see } \\
\text { broader trends, new competition, and strategies that the smaller entities } \\
\text { miss because they are focused on their own industry. }\end{array}$ \\
\hline Thurm (2005) & MBF & $\begin{array}{l}\text { Location; org. } \\
\text { context }\end{array}$ & $\begin{array}{l}\text { Managerial/ } \\
\text { architectural (no } \\
\text { explicit } \\
\text { theoretical lens) }\end{array}$ & $\begin{array}{l}\text { Illustrative case } \\
\text { study of The } \\
\text { New York Times }\end{array}$ & $\begin{array}{l}\text { The CHQ building is an important firm' asset and reflects the firm's } \\
\text { mission and produces a truly energizing work environment. Firms } \\
\text { should take an active role when to make sure that the CHQ building } \\
\text { reflects the firm's identity. }\end{array}$ \\
\hline $\begin{array}{l}\text { Birkinshaw, } \\
\text { Braunerhjelm, } \\
\text { Holm, \& } \\
\text { Terjesen (2006) }\end{array}$ & MNF & $\begin{array}{l}\text { Location; env. } \\
\text { context; roles/ } \\
\text { activities }\end{array}$ & $\begin{array}{l}\text { Multinational } \\
\text { corporation } \\
\text { (MNF), multiple } \\
\text { theoretical lenses }\end{array}$ & $\begin{array}{l}\text { Survey of } 125 \\
\text { BU HQ and } 35 \\
\text { CHQ of large } \\
\text { Swedish MNFs }\end{array}$ & $\begin{array}{l}\text { Firms relocate BU HQ and the CHQ for different reasons: Firms } \\
\text { relocate BU HQ overseas in response to changes in the int. config. and } \\
\text { changing market demands; they relocate their CHQ in response to ext. } \\
\text { stakeholders' demands (int. financial markets and shareholders). }\end{array}$ \\
\hline $\begin{array}{l}\text { Chan \& Makino } \\
(2007)\end{array}$ & MNF & $\begin{array}{l}\text { Org. context; } \\
\text { env. context; } \\
\text { operating units }\end{array}$ & $\begin{array}{l}\text { Institutional } \\
\text { theory }\end{array}$ & $\begin{array}{l}898 \text { Japanese } \\
\text { MNFs, 4,451 } \\
\text { subsidiaries in } 39 \\
\text { countr., 1988-99 }\end{array}$ & $\begin{array}{l}\text { MNF subsidiary ownership choices are influenced by legitimacy } \\
\text { rationales. Specifically, MNFs are likely to take a higher ownership } \\
\text { stake in response to strong internal pressure to sustain their internal } \\
\text { legitimacy at the corporate level of their institutional environment. }\end{array}$ \\
\hline
\end{tabular}




\begin{tabular}{|c|c|c|c|c|c|}
\hline $\begin{array}{l}\text { Author(s) } \\
\text { (Year) }\end{array}$ & $\begin{array}{l}\text { Research } \\
\text { Stream } \\
\end{array}$ & Focus & $\begin{array}{l}\text { Theoretical } \\
\text { Lens }\end{array}$ & Methodology & Key Findings related to the CHQ \\
\hline $\begin{array}{l}\text { Collis, Young, \& } \\
\text { Goold (2007) }\end{array}$ & MBF & $\begin{array}{l}\text { Roles/ activities; } \\
\text { design; org. } \\
\text { context; } \\
\text { outcomes }\end{array}$ & $\begin{array}{l}\text { Organizational } \\
\text { contingency } \\
\text { theory, multiple } \\
\text { theoretical lenses }\end{array}$ & $\begin{array}{l}\text { Survey of } 467 \\
\text { firms in } 7 \\
\text { countries; } 1997- \\
99\end{array}$ & $\begin{array}{l}\text { The size and structure of CHQs depend on the firm size, corporate } \\
\text { strategy, and governance system; further, the fit between the CHQ and } \\
\text { the corporate strategy is critical for superior firm performance. }\end{array}$ \\
\hline $\begin{array}{l}\text { Bouquet \& } \\
\text { Birkinshaw } \\
(2008)\end{array}$ & MNF & $\begin{array}{l}\text { Org. context; } \\
\text { operating units; } \\
\text { outcomes }\end{array}$ & $\begin{array}{l}\text { Attention-based } \\
\text { view }\end{array}$ & $\begin{array}{l}\text { Survey of } 283 \\
\text { foreign } \\
\text { subsidiaries of } \\
\text { large MNFs }\end{array}$ & $\begin{array}{l}\text { CHQ attention is partially based on the BUs' structural positions } \\
\text { within a corporate system, and BUs have a 'voice' that can attract } \\
\text { CHQ attention, but this is moderated by two specific aspects of the } \\
\text { BU's context: geographic distance and downstream competence. }\end{array}$ \\
\hline $\begin{array}{l}\text { Garvin \& } \\
\text { Levesque (2008) }\end{array}$ & MBF & Org. context & $\begin{array}{l}\text { Managerial/ } \\
\text { normative }\end{array}$ & $\begin{array}{l}\text { Qual:: } 13 \\
\text { multiunit } \\
\text { organizations in } \\
2005 \text { and } 2006 \\
\end{array}$ & $\begin{array}{l}\text { In a multiunit enterprise, four tiers of management constitute the field } \\
\text { organization store, district, regional, and divisional heads. All these } \\
\text { managers are responsible for meeting targets set by the CHQ and for } \\
\text { implementing the strategy. }\end{array}$ \\
\hline $\begin{array}{l}\text { Takeuchi, Shay, } \\
\text { \& Li (2008) }\end{array}$ & MNF & $\begin{array}{l}\text { Resources; } \\
\text { integrating } \\
\text { mechanisms; } \\
\text { operating units }\end{array}$ & $\begin{array}{l}\text { Cognitive } \\
\text { dissonance } \\
\text { theory, decision- } \\
\text { making } \\
\end{array}$ & $\begin{array}{l}\text { Survey data; } 187 \\
\text { expatriates, } 24 \\
\text { CHQ executives }\end{array}$ & $\begin{array}{l}\text { Expatriate adjustment is influenced by the decision autonomy afforded } \\
\text { expatriate managers; the relationship is moderated by a parent } \\
\text { company's operational experience with a particular foreign subsidiary. }\end{array}$ \\
\hline $\begin{array}{l}\text { Chen, Park, \& } \\
\text { Newburry } \\
(2009)\end{array}$ & MNF & $\begin{array}{l}\text { Resources; } \\
\text { integrating } \\
\text { mechanisms }\end{array}$ & Control theory & $\begin{array}{l}\text { Survey of } 202 \\
\text { manufacturing } \\
\text { IJVs in China } \\
(2002-03) \\
\end{array}$ & $\begin{array}{l}\text { Hypothesizing that a CHQ's usage of the control type is influenced by } \\
\text { its resource contributions, property-based contribution is linked to } \\
\text { output and process control, and knowledge-based contribution is } \\
\text { related to process and social control. }\end{array}$ \\
\hline $\begin{array}{l}\text { Lange, Boivie, } \\
\& \text { Henderson } \\
(2009)\end{array}$ & MBF & $\begin{array}{l}\text { Env. context; } \\
\text { org. context; } \\
\text { outcomes }\end{array}$ & $\begin{array}{l}\text { Innovation } \\
\text { theory, industry } \\
\text { ecology }\end{array}$ & $\begin{array}{l}\text { Event history } \\
\text { analysis of the } \\
\text { US PC industry, } \\
1975-94 \\
\end{array}$ & $\begin{array}{l}\text { Established firms diversifying into a new industry that originated from } \\
\text { a disruptive technological change, give birth to corporate children that } \\
\text { are both weaker survivors than freestanding start-ups and stronger } \\
\text { legitimators of the industry as a whole. }\end{array}$ \\
\hline $\begin{array}{l}\text { Law, Song, } \\
\text { Wong, \& Chen } \\
(2009)\end{array}$ & MNF & $\begin{array}{l}\text { Resources; org. } \\
\text { context; } \\
\text { outcomes }\end{array}$ & $\begin{array}{l}\text { Resource- } \\
\text { dependence } \\
\text { theory }\end{array}$ & $\begin{array}{l}\text { Survey of } 229 \\
\text { Chinese } \\
\text { subsidiaries of } \\
\text { foreign firms }\end{array}$ & $\begin{array}{l}\text { CHQ support and TMT commitment predict localization success (the } \\
\text { extent to which local employees replace expatriate managers). }\end{array}$ \\
\hline $\begin{array}{l}\text { Ambos, } \\
\text { Andersson, \& } \\
\text { Birkinshaw } \\
(2010)\end{array}$ & MNF & $\begin{array}{l}\text { Operating units; } \\
\text { outcomes }\end{array}$ & $\begin{array}{l}\text { Resource } \\
\text { dependence, self- } \\
\text { determination } \\
\text { theory }\end{array}$ & $\begin{array}{l}\text { Survey; } 257 \\
\text { foreign-owned } \\
\text { subs. in AUS, } \\
\text { CAN, UK }\end{array}$ & $\begin{array}{l}\text { Subsidiaries cannot increase their influence through initiatives unless } \\
\text { they get CHQ's attention. Subsidiary initiatives have a direct effect on } \\
\text { subsidiary autonomy, but the caveat is that initiatives also evoke CHQ } \\
\text { monitoring, which in turn decreases the subsidiary's autonomy. }\end{array}$ \\
\hline $\begin{array}{l}\text { Gospel \& Sako } \\
(2010)\end{array}$ & MBF & $\begin{array}{l}\text { Org. context; } \\
\text { env. context; } \\
\text { roles/ activities; } \\
\text { design }\end{array}$ & $\begin{array}{l}\text { Transaction cost } \\
\text { economics, } \\
\text { resource-based } \\
\text { view }\end{array}$ & $\begin{array}{l}\text { Comparison of } \\
\text { HR outsourcing } \\
\text { in two consumer } \\
\text { products firms }\end{array}$ & $\begin{array}{l}\text { The corporate structure and nature of supplier markets affect the paths } \\
\text { chosen to create shared business services and to move to outsourcing; } \\
\text { the trajectory of the move to shared services and outsourcing affects } \\
\text { the capability distribution between the users and the suppliers. }\end{array}$ \\
\hline
\end{tabular}




\begin{tabular}{|c|c|c|c|c|c|}
\hline $\begin{array}{l}\text { Author(s) } \\
\text { (Year) }\end{array}$ & $\begin{array}{l}\text { Research } \\
\text { Stream }\end{array}$ & Focus & $\begin{array}{l}\text { Theoretical } \\
\text { Lens }\end{array}$ & Methodology & Key Findings related to the CHQ \\
\hline $\begin{array}{l}\text { Ciabuschi, } \\
\text { Dellestrand, \& } \\
\text { Martín (2011) }\end{array}$ & MNF & $\begin{array}{l}\text { Roles/ activities; } \\
\text { integrating } \\
\text { mechanisms; } \\
\text { outcomes }\end{array}$ & $\begin{array}{l}\text { Business network } \\
\text { perspective }\end{array}$ & $\begin{array}{l}\text { Quantitative: } 85 \\
\text { innovation } \\
\text { projects in } 23 \\
\text { MNFs } \\
\end{array}$ & $\begin{array}{l}\text { CHQ involvement in the innovation development process improves } \\
\text { BU competencies. CHQ involvement, driven by BU internal } \\
\text { embeddedness, enhances the innovation impact on the BU, which in } \\
\text { turn influences the innovation importance at the corporate level. }\end{array}$ \\
\hline $\begin{array}{l}\text { Ciabuschi, } \\
\text { Forsgren, \& } \\
\text { Martin }(2011)\end{array}$ & MNF & $\begin{array}{l}\text { Roles/ activities; } \\
\text { integrating } \\
\text { mechanisms; } \\
\text { outcomes }\end{array}$ & $\begin{array}{l}\text { international } \\
\text { business theory }\end{array}$ & $\begin{array}{l}\text { Theory-building: } \\
\text { illustrative case: } \\
\text { Swedish firm and } \\
\text { a US subsidiary }\end{array}$ & $\begin{array}{l}\text { Two alternative approaches explain the impact of CHQ involvement } \\
\text { on the innovation process performance of subsidiaries: (1) the } \\
\text { rationality perspective and (2) the sheer ignorance perspective (the } \\
\text { impossibility of the CHQ to assess ex ante what role to play). }\end{array}$ \\
\hline Crilly (2011) & MNF & $\begin{array}{l}\text { Env. context; } \\
\text { operating units; } \\
\text { outcomes }\end{array}$ & $\begin{array}{l}\text { Stakeholder } \\
\text { theory }\end{array}$ & $\begin{array}{l}\text { Induction and } \\
\text { fuzzy-set } \\
\text { analysis; } 52 \\
\text { overseas subs. }\end{array}$ & $\begin{array}{l}\text { Internal control through the corporate parent can crowd out the voices } \\
\text { of local stakeholders. Further, some corporations are subject to } \\
\text { scrutiny by global stakeholders, and their subsidiaries face higher } \\
\text { requirements for social engagement than their peers do. }\end{array}$ \\
\hline $\begin{array}{l}\text { Parmigiani \& } \\
\text { Holloway (2011) }\end{array}$ & $\mathrm{MBF}$ & $\begin{array}{l}\text { Resources; } \\
\text { outcomes }\end{array}$ & $\begin{array}{l}\text { Organizational } \\
\text { economics, } \\
\text { resource-based } \\
\text { view }\end{array}$ & $\begin{array}{l}\text { Quant. analysis } \\
\text { of } 72 \text { US } \\
\text { restaurant chains; } \\
1998-2007\end{array}$ & $\begin{array}{l}\text { CHQ-level impl. capabilities of operating expertise gained through } \\
\text { related experience and coordination from collocation combined with } \\
\text { governance mode choices jointly affect performance; CHQ capabilities } \\
\text { may be more important than mode choice fit. }\end{array}$ \\
\hline $\begin{array}{l}\text { Semadeni \& } \\
\text { Cannella (2011) }\end{array}$ & $\mathrm{MBF}$ & $\begin{array}{l}\text { Org. context; } \\
\text { operating units; } \\
\text { outcomes }\end{array}$ & $\begin{array}{l}\text { Transaction cost } \\
\text { theory, agency } \\
\text { theory }\end{array}$ & $\begin{array}{l}\text { Quant. analysis; } \\
142 \text { spin-offs of } \\
\text { listed US firms; } \\
1986-97\end{array}$ & $\begin{array}{l}\text { While child firms benefit from some post spin-off links to the parent } \\
\text { (monitoring by CHQ executives), having too many links is negatively } \\
\text { related to performance. The findings suggest that there is a balance } \\
\text { between having too much CHQ involvement and not enough. }\end{array}$ \\
\hline $\begin{array}{l}\text { Alfoldi, Clegg, } \\
\& \text { McGaughey } \\
(2012)\end{array}$ & MNF & $\begin{array}{l}\text { Org. context; } \\
\text { integrating } \\
\text { mechanims }\end{array}$ & $\begin{array}{l}\text { Contingency, } \\
\text { agency, } \\
\text { information- } \\
\text { processing theory }\end{array}$ & $\begin{array}{l}\text { Case study: } \\
\text { Unilever } \\
\text { Hungary }\end{array}$ & $\begin{array}{l}\text { Delegating CHQ functions to local BUs has benefits: it balances } \\
\text { integration and responsiveness at levels below the efficient scale for } \\
\text { RHQ; exploits local operational expertise on a regional level; relieves } \\
\text { the CHQ of the burden of monitoring remote peripheral agents. }\end{array}$ \\
\hline $\begin{array}{l}\text { Baaij, Mom, } \\
\text { Van Den Bosch, } \\
\& \text { Volberda } \\
(2012 a)\end{array}$ & MNF & $\begin{array}{l}\text { Location; env. } \\
\text { context; } \\
\text { outcomes }\end{array}$ & $\begin{array}{l}\text { Managerial/ } \\
\text { normative (no } \\
\text { explicit } \\
\text { theoretical lens) } \\
\end{array}$ & $\begin{array}{l}\text { Survey of } 58 \\
\text { Dutch MNFs; } \\
\text { illustrative cases }\end{array}$ & $\begin{array}{l}\text { The increasing internationalization of markets and industries is a driver } \\
\text { of the international relocation of CHQ elements. Companies should } \\
\text { assess the strategic benefits and costs of relocation and consider using } \\
\text { communication technologies following the relocation. }\end{array}$ \\
\hline $\begin{array}{l}\text { Baaij, Mom, } \\
\text { Van Den Bosch, } \\
\& \text { Volberda } \\
(2012 b)\end{array}$ & MNF & $\begin{array}{l}\text { Location; env. } \\
\text { context; org. } \\
\text { context; } \\
\text { outcomes }\end{array}$ & $\begin{array}{l}\text { No explicit } \\
\text { theoretical lens }\end{array}$ & $\begin{array}{l}\text { Quantitative: } 58 \\
\text { of the } 100 \text { largest } \\
\text { Dutch MNFs }\end{array}$ & $\begin{array}{l}\text { Relocation of CHQ core parts is driven by DOI and the perceived } \\
\text { attractiveness of the home country. Relocation benefits are: better } \\
\text { communication with overseas stakeholders; access to international } \\
\text { resources; and access to better fiscal, legal. and regulatory regimes. }\end{array}$ \\
\hline $\begin{array}{l}\text { Campbell, } \\
\text { Kunisch, \& } \\
\text { Müller-Stewens } \\
\text { (2012) }\end{array}$ & $\mathrm{MBF}$ & $\begin{array}{l}\text { Design; org. } \\
\text { context }\end{array}$ & $\begin{array}{l}\text { Managerial/ } \\
\text { normative } \\
\text { (parenting } \\
\text { theory) }\end{array}$ & $\begin{array}{l}\text { Interviews with } \\
50 \text { function heads } \\
\text { of European } \\
\text { firms }\end{array}$ & $\begin{array}{l}\text { CHQ functional units should receive more guidance from CEOs in } \\
\text { order to contribute to corporate success; four ways can help: (1) define } \\
\text { major sources of value added, (2), review CHQ units annually, (3) use } \\
\text { corporate initiative matrix, and (4) separate shared services. }\end{array}$ \\
\hline
\end{tabular}




\begin{tabular}{|c|c|c|c|c|c|}
\hline $\begin{array}{l}\text { Author(s) } \\
\text { (Year) }\end{array}$ & $\begin{array}{l}\text { Research } \\
\text { Stream } \\
\end{array}$ & Focus & $\begin{array}{l}\text { Theoretical } \\
\text { Lens } \\
\end{array}$ & Methodology & Key Findings related to the CHQ \\
\hline $\begin{array}{l}\text { Collis, Young, \& } \\
\text { Goold (2012) }\end{array}$ & MNF & $\begin{array}{l}\text { Design; env. } \\
\text { context; org. } \\
\text { context (GSS); } \\
\text { outcomes }\end{array}$ & $\begin{array}{l}\text { Organizational } \\
\text { contingency } \\
\text { theory, multiple } \\
\text { theoretical lenses }\end{array}$ & $\begin{array}{l}\text { Survey of } 250 \\
\text { MNF in } 6 \\
\text { countries; } 1997- \\
1999\end{array}$ & $\begin{array}{l}\text { MNF CHQ are more involved in "obligatory," value creating and } \\
\text { control functions than in operational activities; the CHQ size expands } \\
\text { as the MNF geographic scope increases. The substantially differing } \\
\text { CHQ sizes of MNFs from different countries indicates "administrative } \\
\text { heritage." }\end{array}$ \\
\hline $\begin{array}{l}\text { Foss, Foss, \& } \\
\text { Nell (2012) }\end{array}$ & MNF & $\begin{array}{l}\text { Org. context } \\
\text { (GSS); } \\
\text { integrating } \\
\text { mechanisms }\end{array}$ & $\begin{array}{l}\text { International } \\
\text { business, } \\
\text { organizational } \\
\text { behavior }\end{array}$ & $\begin{array}{l}\text { Conceptual; } \\
\text { theory building }\end{array}$ & $\begin{array}{l}\text { Network MNFs should be particularly careful to anticipate and take } \\
\text { precautions against CHQ 'intervention hazards.' Normative integration } \\
\text { and procedural justice also serve to control harmful CHQ interventions } \\
\text { (and not just subsidiary opportunism). }\end{array}$ \\
\hline $\begin{array}{l}\text { Joseph \& Ocasio } \\
(2012)\end{array}$ & $\mathrm{MBF}$ & $\begin{array}{l}\text { Integrating } \\
\text { mechanisms; } \\
\text { operating units; } \\
\text { outcomes }\end{array}$ & $\begin{array}{l}\text { Organization } \\
\text { design, multiple } \\
\text { lenses }\end{array}$ & $\begin{array}{l}\text { Qual.: inductive } \\
\text { analysis of GE's } \\
\text { gov. system from } \\
1951 \text { to } 2001\end{array}$ & $\begin{array}{l}\text { Collective vertical CHQ-BU interactions happen through cross-level } \\
\text { channels; temporal coupling integrates levels and issues simultaneous- } \\
\text { ly, yet centers attention sequentially, providing more effective } \\
\text { conditions for joint attention and coordination betw. the CHQ and BU. }\end{array}$ \\
\hline $\begin{array}{l}\text { Laamanen, } \\
\text { Simula, \& } \\
\text { Torstila (2012) }\end{array}$ & MNF & $\begin{array}{l}\text { Location; env. } \\
\text { context; org. } \\
\text { context }\end{array}$ & $\begin{array}{l}\text { Economic/ } \\
\text { regional } \\
\text { development; int. } \\
\text { business }\end{array}$ & $\begin{array}{l}52 \text { CHQ and } \\
\text { RHQ relocations } \\
\text { in Europe; } 1996- \\
2006\end{array}$ & $\begin{array}{l}\text { There is an increasing trend toward CHQ/RHQ relocation. High taxes } \\
\text { and a high employment rate are push factors that increase the } \\
\text { likelihood of relocation. A central location and low taxes are pull } \\
\text { factors that increase the attractiveness of the HQ location. }\end{array}$ \\
\hline $\begin{array}{l}\text { Mahnke, Ambos, } \\
\text { Nell, \& Hobdari } \\
(2012)\end{array}$ & MNF & $\begin{array}{l}\text { Org. context } \\
\text { (GSS); operating } \\
\text { units; outcomes }\end{array}$ & Decision-making & $\begin{array}{l}\text { Quant.: survey of } \\
42 \text { RHQ in } 5 \\
\text { countries }\end{array}$ & $\begin{array}{l}\text { RHQ can serve as a vital source of knowledge and input, and a bridge } \\
\text { between local BUs and the CHQ. RHQ's autonomy and signaling } \\
\text { behavior have significant effects on its influence on corporate strategy, } \\
\text { and the RHQ's charter moderates such bottom-up influence. }\end{array}$ \\
\hline $\begin{array}{l}\text { Tomassen, } \\
\text { Benito, \& } \\
\text { Lunnan (2012) }\end{array}$ & MNF & $\begin{array}{l}\text { Outcomes; env. } \\
\text { context; } \\
\text { operating units }\end{array}$ & $\begin{array}{l}\text { Transaction cost } \\
\text { and } \\
\text { internalization } \\
\text { theories }\end{array}$ & $\begin{array}{l}\text { Quant:: } 159 \\
\text { MNF-subsidiary } \\
\text { relationships; } \\
\text { Norway }\end{array}$ & $\begin{array}{l}\text { CHQ governance costs (establishing subsidiaries abroad) are driven by } \\
\text { external contingencies, as well as factors that characterize a particular } \\
\text { CHQ-subsidiary relationship. }\end{array}$ \\
\hline $\begin{array}{l}\text { Vahlne, } \\
\text { Schweizer, \& } \\
\text { Johanson (2012) }\end{array}$ & MNF & $\begin{array}{l}\text { Resources; } \\
\text { operating units }\end{array}$ & Network theory & Conceptual & $\begin{array}{l}\text { The CHQ management process that coordinates and manages the } \\
\text { global firm is characterized by uncertainty, which is due to its liability } \\
\text { of outsidership, which is derived from the CHQ often not being } \\
\text { knowledgeable about its subsidiaries' networks and actions. }\end{array}$ \\
\hline $\begin{array}{l}\text { Kownatzki, } \\
\text { Walter, Floyd, \& } \\
\text { Lechner (2013) }\end{array}$ & $\mathrm{MBF}$ & $\begin{array}{l}\text { Integrating } \\
\text { mechanisms; } \\
\text { outcomes }\end{array}$ & Control theory & $\begin{array}{l}\text { Multi-method } \\
\text { (qual. and quant. } \\
\text { analyses): five } \\
\text { internat. MBF }\end{array}$ & $\begin{array}{l}\text { Three corporate control types enhance SBU decision speed; two have } \\
\text { no effect; and one has a negative effect. Transparency/alignment, } \\
\text { outcome orientation, participation, trust, and timely feedback are the } \\
\text { key mechanisms accounting for these effects. }\end{array}$ \\
\hline $\begin{array}{l}\text { Nell \& Ambos } \\
\text { (2013) }\end{array}$ & MNF & $\begin{array}{l}\text { Env. context; } \\
\text { outcomes; } \\
\text { operating units }\end{array}$ & $\begin{array}{l}\text { Network theory } \\
\text { (embeddedness } \\
\text { perspective); } \\
\text { parenting theory }\end{array}$ & $\begin{array}{l}\text { Quant. analysis: } \\
\text { survey of } 124 \\
\text { subsidiaries in } \\
\text { Europe }\end{array}$ & $\begin{array}{l}\text { MNF external embeddedness influences the CHQ's value creation: The } \\
\text { CHQ's investments in its relationships with its subsidiaries' contexts is } \\
\text { positively related to the CHQ's value added. This relationship is } \\
\text { stronger if the subsidiary is strongly embedded. }\end{array}$ \\
\hline
\end{tabular}




\begin{tabular}{|c|c|c|c|c|c|}
\hline $\begin{array}{l}\text { Author(s) } \\
\text { (Year) }\end{array}$ & \begin{tabular}{|l|} 
Research \\
Stream \\
\end{tabular} & Focus & $\begin{array}{l}\text { Theoretical } \\
\text { Lens }\end{array}$ & Methodology & Key Findings related to the CHQ \\
\hline $\begin{array}{l}\text { Sengul \& } \\
\text { Gimeno (2013) }\end{array}$ & $\begin{array}{l}\text { MBF } \\
\text { (multi- } \\
\text { industry } \\
\text { firms) }\end{array}$ & $\begin{array}{l}\text { Integrating } \\
\text { mechanisms; org. } \\
\text { context; } \\
\text { outcomes }\end{array}$ & $\begin{array}{l}\text { Organization } \\
\text { design; strategic } \\
\text { delegation }\end{array}$ & $\begin{array}{l}\text { Quant: majority- } \\
\text { owned subs. of } \\
\text { French groups; } \\
\text { 1997-2004 }\end{array}$ & $\begin{array}{l}\text { Although firms competing in multiple industries delegate most } \\
\text { business-level decisions to their BUs, they adjust these mechanisms to } \\
\text { multimarket competition by constraining the scope of their BUs' } \\
\text { decision rights and their available resources ('constrained delegation'). }\end{array}$ \\
\hline $\begin{array}{l}\text { Surroca, Tribo, } \\
\text { \& Zahra (2013) }\end{array}$ & MNF & $\begin{array}{l}\text { Ext. context; } \\
\text { CHQ-subsidiary } \\
\text { relations; } \\
\text { operating units }\end{array}$ & $\begin{array}{l}\text { Institutional } \\
\text { theory }\end{array}$ & $\begin{array}{l}\text { Panel data; } 269 \\
\text { subsidiaries of } \\
110 \text { MNFs from } \\
22 \text { countries }\end{array}$ & $\begin{array}{l}\text { Mounting stakeholder pressure in an MNF's home country leads to the } \\
\text { transfer of socially irresponsible practices from its CHQ to its overseas } \\
\text { subsidiaries. This transfer is more pronounced if a subsidiary is } \\
\text { characterized by certain conditions. }\end{array}$ \\
\hline $\begin{array}{l}\text { Arrfelt, } \\
\text { Wiseman, } \\
\text { McNamara, \& } \\
\text { Hult (2014) }\end{array}$ & $\mathrm{MBF}$ & $\begin{array}{l}\text { Roles/ activities; } \\
\text { outcomes }\end{array}$ & $\begin{array}{l}\text { Dynamic } \\
\text { capabilities, } \\
\text { contingency view }\end{array}$ & $\begin{array}{l}3,660 \text { BUs nested } \\
\text { within } 1,137 \\
\text { corporations and } \\
418 \text { industries }\end{array}$ & $\begin{array}{l}\text { Lower levels of allocation competency in the form of excess } \\
\text { investment in BUs with relatively poorer future prospects reduce BU } \\
\text { performance. Market conditions affect the performance implications of } \\
\text { capital allocation-allocation competency is more salient in more } \\
\text { competitive markets. }\end{array}$ \\
\hline $\begin{array}{l}\text { Kleinbaum \& } \\
\text { Stuart (2014) }\end{array}$ & $\mathrm{MBF}$ & Design & Network theory & $\begin{array}{l}\text { Quant. case study } \\
\text { analysis: e-mail } \\
\text { analysis }\end{array}$ & $\begin{array}{l}\text { Corporate staff have networks that are larger, more integrative, and } \\
\text { richer in structural holes, mainly due to the sorting processes, rather } \\
\text { than the corporate tasks per se. People who have received a 'corporate } \\
\text { imprimatur,' retain it even when they move back to the operating unit. }\end{array}$ \\
\hline $\begin{array}{l}\text { Plourde, Parker, } \\
\text { \& Schaan (2014) }\end{array}$ & MNF & $\begin{array}{l}\text { Operating units; } \\
\text { env. context; } \\
\text { CHQ outcomes }\end{array}$ & $\begin{array}{l}\text { Attention-based } \\
\text { view; cognitive }\end{array}$ & $\begin{array}{l}\text { Quant.: Subs. of } \\
\text { a mid-sized } \\
\text { Japanese MNE } \\
(1997-2006) \\
\end{array}$ & $\begin{array}{l}\text { Subsidiaries hosting expatriates and experiencing growth at the } \\
\text { subsidiary or market levels have a higher probability of capturing the } \\
\text { CHQ's attention, i.e. allowing the CHQ to recognize information } \\
\text { signaling opportunities that could otherwise go unnoticed. }\end{array}$ \\
\hline $\begin{array}{l}\text { Hoenen \& } \\
\text { Kostova (2014) }\end{array}$ & MNF & $\begin{array}{l}\text { CHQ-subsidiary } \\
\text { relations }\end{array}$ & Agency theory & Theory & $\begin{array}{l}\text { Advancement in agency theory resolves issues of CHQ-subs. relations } \\
\text { incl. the gap between CHQ expectations and subs. performance, nested } \\
\text { hierarchical relationships across multiple org. layers, and relationships } \\
\text { across diverse subunits embedded in different social contexts. }\end{array}$ \\
\hline $\begin{array}{l}\text { Walter, } \\
\text { Heinrichs, \& } \\
\text { Walter (2014) }\end{array}$ & $\begin{array}{l}\text { Not clear } \\
\text { (more } \\
\text { MBF than } \\
\text { MNF) }\end{array}$ & $\begin{array}{l}\text { CHQ-operating } \\
\text { units relations; } \\
\text { outcomes }\end{array}$ & $\begin{array}{l}\text { Embeddedness } \\
\text { perspective }\end{array}$ & $\begin{array}{l}144 \text { technology } \\
\text { spin-outs in } \\
\text { Germany }\end{array}$ & $\begin{array}{l}\text { Indicating negative, conflict-laden relationships between CHQ and } \\
\text { (former) subsidiaries, spin-outs suffer the negative consequences of } \\
\text { CHQ hostility (the degree to which an incumbent firm disapproves of } \\
\text { the spin-out). Spin-outs can lessen them through effective network } \\
\text { development. }\end{array}$ \\
\hline
\end{tabular}

* The research focus noted in the third column refers to the framework of CHQ research illustrated in Figure 2.

** To facilitate reading, we replaced the different terms for CHQ found in the literature by CHQ. BU = business unit; CHQ = corporate headquarters; IJV = international joint venture; $\mathrm{MBF}=$ multibusiness firm; $\mathrm{MNF}=$ multinational firm; $\mathrm{RHQ}=$ regional headquarters; CSS = corporate strategy and structure; GSS = global strategy and structure; EVA = Economic Value Added; DOI = Degree of Internationalization. 